University of Nebraska - Lincoln

DigitalCommons@University of Nebraska - Lincoln

USGS Staff -- Published Research

US Geological Survey

2011

Factors Controlling Pre-Columbian and Early Historic Maize Productivity in the American Southwest, Part 1: The Southern Colorado Plateau and Rio Grande Regions

Larry V. Benson

U.S. Geological Survey, great.basin666@gmail.com

Follow this and additional works at: http://digitalcommons.unl.edu/usgsstaffpub

Part of the Archaeological Anthropology Commons, and the Other History of Art, Architecture, and Archaeology Commons

Benson, Larry V., "Factors Controlling Pre-Columbian and Early Historic Maize Productivity in the American Southwest, Part 1: The Southern Colorado Plateau and Rio Grande Regions" (2011). USGS Staff -- Published Research. 745.

http:// digitalcommons.unl.edu/usgsstaffpub/745

This Article is brought to you for free and open access by the US Geological Survey at DigitalCommons@University of Nebraska - Lincoln. It has been accepted for inclusion in USGS Staff -- Published Research by an authorized administrator of DigitalCommons@University of Nebraska - Lincoln. 


\title{
Factors Controlling Pre-Columbian and Early Historic Maize Productivity in the American Southwest, Part 1: The Southern Colorado Plateau and Rio Grande Regions
}

\author{
Larry V. Benson
}

Published online: 18 May 2010

(C) US Government 2010

\begin{abstract}
Maize is the New World's preeminent grain crop and it provided the economic basis for human culture in many regions within the Americas. To flourish, maize needs water, sunlight (heat), and nutrients (e.g., nitrogen). In this paper, climate and soil chemistry data are used to evaluate the potential for dryland (rainon-field) agriculture in the semiarid southeastern Colorado Plateau and Rio Grande regions. Processes that impact maize agriculture such as nitrogen mineralization, infiltration of precipitation, bare soil evaporation, and transpiration are discussed and evaluated. Most of the study area, excepting high-elevation regions, receives sufficient solar radiation to grow maize. The salinities of subsurface soils in the central San Juan Basin are very high and their nitrogen concentrations are very low. In addition, soils of the central San Juan Basin are characterized by $\mathrm{pH}$ values that exceed 8.0, which limit the availability of both nitrogen and phosphorous. In general, the San Juan Basin, including Chaco Canyon, is the least promising part of the study area in terms of dryland farming. Calculations of field life, using values of organic nitrogen for the upper $50 \mathrm{~cm}$ of soil in the study area, indicate that most of the study area could not support a 10-bushel/acre crop of maize. The concepts, methods, and calculations used to quantify maize productivity in this study are applicable to maize cultivation in other environmental settings across the Americas.
\end{abstract}

Keywords Southwest $\cdot$ Maize agriculture $\cdot$ Soil chemistry

Electronic supplementary material The online version of this article (doi:10.1007/s10816-010-9082-z) contains supplementary material, which is available to authorized users.

L. V. Benson $(\bowtie)$

National Research Program, U.S. Geological Survey, 3215 Marine St., Boulder, CO 80303, USA e-mail: lbenson@usgs.gov 


\section{Introduction}

The genetic plasticity of maize (Zea mays L.) has permitted its adaptation to a wide spectrum of environments. It grows at elevations ranging from 0 to 3,000 $\mathrm{m}$ (above sea level), at latitudes ranging from zero to $50^{\circ} \mathrm{N}$ and $50^{\circ} \mathrm{S}$, under precipitation regimes ranging from wet to semiarid, and in both temperate and tropical climates (see, e.g., Corral et al. 2008).

Maize is the New World's preeminent grain crop and it provided the economic basis for many cultures in the Americas. Its ancestor, teosinte (Zea mays ssp. parviglumis) was domesticated in the Balsas drainage of central Mexico (Matsuoka et al. 2002). Accelerator mass spectrometric dates on maize cobs from southwestern Mexico indicate that domestication occurred more than 6,300 years ago (Benz 2001; Piperno and Flannery 2001). Maize is commonly present in archaeological contexts in the Tehaucan Valley of Mexico by 3550 B.C. (Benz et al. 2006), and it appears in northern Mexico and the American Southwest by about 2900 B.C. (Huckell 2006; Jaenicke-Despres and Smith 2006). Maize has been shown to be a dietary staple of late Basketmaker II (A.D. 1-500) people (Coltrain et al. 2006, 2007). From the American Southwest, maize moved east into the Midwestern USA by about A.D. 330 (Ford 1987), although it was not found in substantial frequencies in archaeobotanical assemblages older than A.D. 1000 (Wymer 1992). Interestingly, Blake (2006) has suggested that the initial use and spread of Zea was due to the value of its stalks in producing large quantities of fermentable juice; that is, it was consumed in a social context.

While there has been some disagreement about the timing of maize introduction to the Old World, it appears that it arrived there soon after Columbus' first voyage to the New World and had reached China before A.D. 1511 (Li 2009). Since A.D. 1500, the world's population has increased by over an order of magnitude, and the addition of Native American food plants, especially maize, has permitted much of the population increase, with world maize production reaching 770 million metric tons in 2008 (Cattlenetwork 2008).

This study seeks to describe the biological, physical, and chemical processes that control maize productivity in a particular semiarid region - the American Southwest. The concepts, methods, and calculations used to quantify maize productivity in this study can be applied to maize cultivation in other environmental settings (modern and prehistoric) that presently exist or have existed around the globe.

In Part 1 of this study, the dependence of Southwestern maize agriculture on climate and soil fertility is examined. The principal factors (water, heat, and soil chemistry) that control maize productivity are discussed. Then, the overall agricultural productivity of the study area (Fig. 1) is evaluated in terms of these factors. The study area includes parts of four states-Utah, Colorado, New Mexico, and Arizona - and is largely contained within the southeastern quadrant of the Colorado Plateau and the northern Rio Grande region. Also discussed are prehistoric and early historic Native American strategies that were developed to optimize and sustain maize agriculture in the semiarid study area. The concepts developed in this paper are applied in Part 2 of this study in order to evaluate the relative agricultural potential of four specific archaeological regions (the Chaco Halo, Mesa Verde, the Pajarito Plateau, and Zuni) found within the study area. 


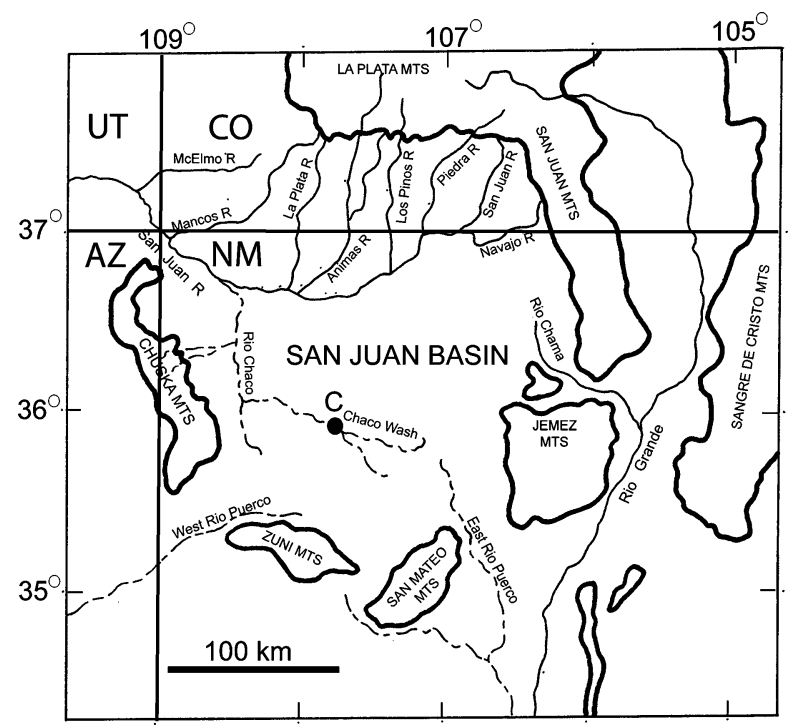

Fig. 1 Study area location map. C Chaco Canyon

This study introduces certain calculations and concepts that illustrate a variety of physical and chemical processes that determine maize productivity. However, there are a number of input parameters to those calculations that need further refinement; for example, little is known regarding the physical and chemical properties of maize grown by prehistoric Southwestern Native Americans. Parameters such as rooting depth, dry weight, and nitrogen concentration in the aboveground plant, optimum length of growing season, and minimum summer and winter precipitation requirements are only roughly known. Because of this, biological and agronomical calculations introduced in this study will often be forced to use values for the physical and chemical characteristics of modern hybrid maize. Data are also absent with regard to prehistoric farming practices, e.g., hill spacing, seeds per hill, weed control, etc. Because of this, the early historic farming practices of the Hopi and Zuni will be used to model prehistoric maize production. In addition, the physical and chemical conditions of present-day soils may not be totally representative of soils that typified the study area hundreds of years ago; for example, many parts of the study area were overgrazed during the late nineteenth century and early twentieth century, and as a result, surface soils in those regions were lost to erosion. This study will therefore principally serve as a framework for agronomic calculations and concepts. In the future, such calculations can be refined as new data become available.

In a recent paper, Benson and Berry (2009) demonstrated that prehistoric Southwestern Native American populations were strongly impacted by climate change; that is, during wet periods, populations increased and people moved into and developed normally marginal agricultural lands. Conversely, during megadroughts, agriculturally unproductive regions were abandoned and populations declined.

Figure 2 illustrates the effect of climate change on timber cutting and construction activities in the southern Colorado Plateau and Rio Grande areas between A.D. 900 


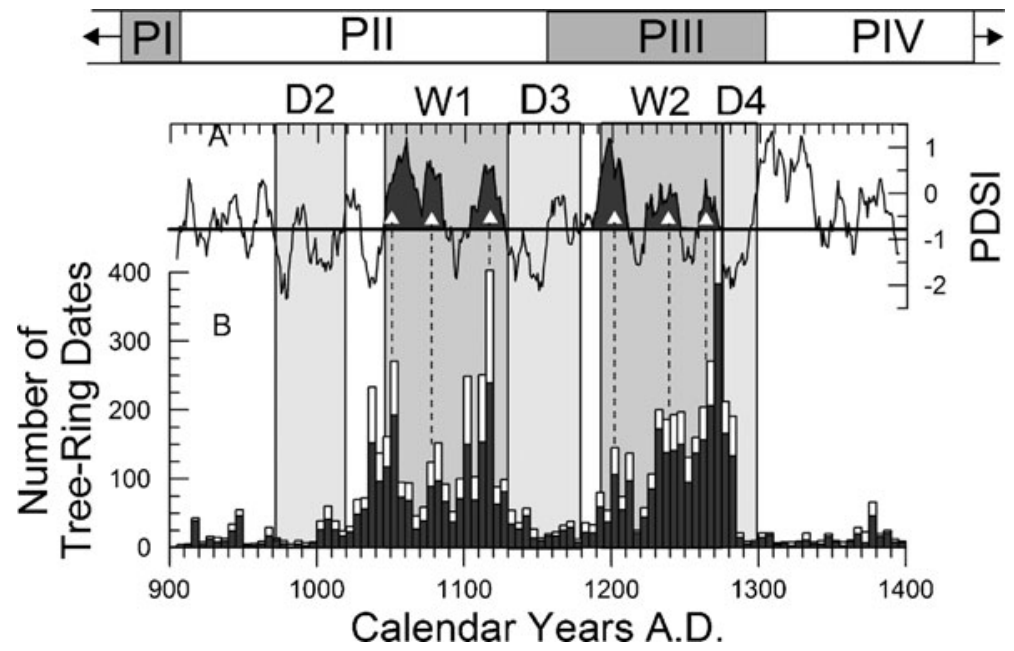

Fig. 2 Comparison of pan-regional tree cutting date distribution with the PDSI climate index. a Mean of nine PDSI records from the southern Colorado Plateau. Baseline has been set at a PDSI of -0.5 , the mean value for the past 2,000 years. PDSI and precipitation values have been smoothed with an 11-year running average. b Distribution of tree ring dates for the period A.D. 900-1400. Black values indicate "death" dates and white values indicate "v" dates. Three megadroughts (D2-D4) have been colored light gray; two extended wet periods (W1-W2) have been colored dark gray. Dashed lines between cutting date distribution and PDSI curves during W1 and W2 indicate correlations of exceptionally wet times with intense tree harvesting and construction. P indicates Pueblo cultural stages. See Fig. 1 in Benson and Berry (2009) for locations of the PDSI sites

and 1400. In Fig. 2, the tree ring date distribution for archaeological sites within these areas is compared with the mean Palmer Drought Severity Index (PDSI) for nine sites within the region (see Benson and Berry 2009 for details regarding the construction of this figure). Negative values of the PDSI indicate times of drought. It is evident from the data displayed in this figure that construction activities accelerated during wet periods and declined during dry periods. Although there is no way of quantitatively linking cutting date numbers to numbers of people, it is reasonable to assume that accelerated building construction occurs in response to population increase and vice versa.

It is the thesis of this paper that Southwestern Native American responses to major swings in climate were principally due to the impact of climate change on maize agriculture in this semiarid region and to human degradation of the natural environment. It also should be noted that multidecadal droughts also negatively impact food resources within the natural system; for example, recent drought has been blamed for the death of millions of nut-producing pinyon pines throughout the Southwest (Breshears et al. 2005).

\section{Maize Productivity}

To flourish, maize needs water, solar radiation, nutrients, and a well-structured soil. In the following, each of these requirements is discussed. Because most references to maize productivity in the archaeological literature is in terms of bushels/acre (bu/ac) 
grain, this quantity will generally be used; however, those preferring the metric system will note that $1 \mathrm{bu} / \mathrm{ac}=56 \mathrm{lb} / \mathrm{ac}=62.8 \mathrm{~kg} / \mathrm{ha}$.

\section{Southwestern and Midwestern Maize Plant Densities}

Optimum yield refers to plant density optimized in terms of growing costs versus selling price. If, for example, the price per bushel of maize increases, as it has due to ethanol production in recent years (Ethanol Statistics 2008), then the optimum plant density will increase. In the humid Midwestern Corn Belt, the optimum yield of grain today occurs at a density of $~ 32,000$ plants/ac (Elmore and Abendroth 2008; Nafziger 2002).

Early historic Zuni and Hopi Native Americans planted 10-20 maize kernels in 15- to 30-cm-deep holes spaced about $3 \mathrm{~m}$ apart (Bradfield 1971; Cushing 1920; Prevost et al. 1984; Stephen 1936). Note that the Hopi generally plant deeper than most other Southwestern Native American groups. After the maize sprouted, all but four or five of the most vigorous sprouts were pulled (Cushing 1920), which reduced hill density to $\sim 440$ hills/ac and plant density to $\sim 2,000$ plants/ac. Throughout this paper, we assume that these hill and plant density values were typical of prehistoric Southwestern Native American agricultural practices.

Maize is a grass whose root length density and mass decreases exponentially with depth (Dwyer et al. 1996; Fehrenbacher and Rust 1956; Qin et al. 2006). As a rule of thumb, about $75 \%$ of the maize root length is concentrated in the upper half of the rooting depth. Because maize is a grass, it concentrates its roots near the surface in order to intercept infiltrating water. The upper root ball radii of some types of modern hybrid maize extend $1.2 \mathrm{~m}$ outward from the stalk (Weaver 1926). Data describing the density and distribution of roots associated with southwestern Native American maize varieties are lacking; however, these varieties also may be able to spread their roots as widely as modern hybrid varieties, thus accessing moisture far from the stalk. If so, this strategy provides the plant with water that infiltrates $\sim 4.5 \mathrm{~m}^{2}$ of soil. For the Southwest, where an average of 4.5 stalks were grown in a single hill, each stalk accesses water infiltrating through an effective $1-\mathrm{m}^{2}$ area. Contrast this with a modern Midwestern 1-ac field containing 32,000 plants in which each plant accesses water infiltrating through a $0.125-\mathrm{m}^{2}$ area. Thus, even though the Southwest receives only a fraction of the precipitation falling on Midwestern fields (most of Illinois and Iowa fields receive $0.75-1.15 \mathrm{~m}$ of annual precipitation, whereas most of New Mexico receives $0.15-0.40 \mathrm{~m}$ of annual precipitation; Oregon Climate Service 2009), Southwestern maize crops can access water from about eight times the soil volume available to Midwestern crops.

\section{Water}

The mass balance for soil water associated with a maize field is given by

$$
\Delta S=\left(I_{\mathrm{P}}+I_{I}\right)-\left(O_{E}+O_{T, W}+O_{T, C}+O_{C}+O_{\downarrow}\right)
$$

where $\Delta S$ is the change in soil moisture storage, $I_{\mathrm{P}}$ is on-field precipitation, $I_{\mathrm{I}}$ is onfield irrigation run-on, $O_{\mathrm{E}}$ is bare soil evaporation, $O_{\mathrm{T}, \mathrm{W}}$ is water transpired from 
weeds, $O_{\mathrm{T}, \mathrm{C}}$ is water transpired from maize, $O_{\mathrm{C}}$ is water stored in maize, and $O_{\downarrow}$ is water that infiltrates below root depth.

\section{On-Field Precipitation}

On-field precipitation and on-field water concentration (a form of dryland irrigation) lead to infiltration and percolation of water through the soil. Brady and Weil (2008) present a simplified overview of soil-water interactions. In the following, I discuss some of those interactions in terms of the concepts presented by these authors.

A summer rainfall of $15 \mathrm{~cm}$ and an annual precipitation of $30 \mathrm{~cm}$ represent, approximately, the lower limits for dryland (rain-on-field) maize production in the northern hemisphere (Shaw 1988). With regard to regions near the study area, Leonard et al. (1940) observed that crop failures in Colorado usually occurred when annual rainfall was $<35 \mathrm{~cm}$, and Jenkins (1941) suggested that precipitation of $20 \mathrm{~cm}$ during June, July, and August marked the western limit of maize production in the USA. Winter and early spring precipitation is necessary to germinate and sprout maize, whereas summer precipitation supplies the necessary moisture for further plant growth, including grain production. Soil moisture in the spring and early summer is necessary for nitrogen $(\mathrm{N})$ mineralization. Timing of precipitation also is important; for example, rainfall is critical with respect to maize yields during the week preceding and the week following anthesis when male flowering and pollen shed begin (Runge 1968).

\section{Infiltration and Percolation of Precipitation}

Infiltration is the penetration of water below the soil surface and percolation is the continued downward transport of water under a potential gradient. The depth of percolation is important because evaporation can rapidly remove much of the moisture in the upper several centimeters of soil during the warm season, thus depriving plants of moisture.

Water flows from high- to low-energy locations. In the case of soils, energy exists mostly in the form of potential energy. The total soil-water potential, $\Psi_{\mathrm{T}}$, principally consists of two potentials, i.e.,

$$
\Psi_{T}=\Psi_{g}+\Psi_{p}
$$

where $\Psi_{\mathrm{g}}$ and $\Psi_{\mathrm{p}}$ are the gravitational and pressure potentials, respectively. The gravitational potential is simply the vertical distance above an arbitrary reference point. The negative pressure potential (matric potential) is mainly due to water tension resulting from the attraction of water to the mineral soil surface.

When all soil pores are saturated with water, the soil is at its maximum retentive capacity and its matric potential approaches zero. At this point, the volumetric water content $\left(\Theta_{v}\right.$, the volume of water associated with a given volume of soil) is equal to the soil's total porosity. If the base of the soil is porous, water will percolate downward and through the soil profile under the influence of gravity. After about 2 days, percolation will cease, and the soil will have achieved its field capacity. At this point, water has been lost from the soil's macropores, but is still contained within its micropores (capillary water) under surface tension. The roots of maize can access capillary water; however, continued depletion of this water will ultimately 
result in a situation where the soil water's negative matric potential exceeds the positive pressure potential created by plant transpiration. At this time, the plant has reached its permanent wilting point. Plant-available water is defined as the volumetric difference between field capacity and the permanent wilting point. Silt loams have field capacity, permanent wilting point, and plant-available water values of about $0.30,0.15$, and $0.15 \mathrm{~g} \mathrm{H}_{2} \mathrm{O} / \mathrm{g}$ dry soil (see, e.g., Norton and Silvertooth 1998). The permanent wilting point also is a function of the negative-pressure osmotic potential $\left(\Psi_{\mathrm{O}}\right)$ which defines the salinity stress experienced by a plant (Homaee et al. 2002). In other words, the increased concentration of dissolved solids in soil water that has experienced evapotranspiration makes it more difficult for a plant's root system to extract water from the soil and, therefore, increases the value of the permanent wilting point and decreases the amount of plant-available water.

Infiltration and percolation of water into a silt loam is depicted in Fig. 3a. In this experiment, $6.1 \mathrm{~cm}$ of water was applied at controlled pressure to a $100-\mathrm{cm}$-long column of soil (Biswas et al. 1966). The rate of water percolation slows with time, and the water's leading edge can be fit with an equation of the form

$$
\ln D=A \ln t+B
$$

where $D$ is depth (cm), $t$ is time (h), and $A$ and $B$ are constants. Extrapolation of the data for front penetration at $0 \mathrm{~h}$ and 30 days into the silt loam (Fig. 4a) indicates that

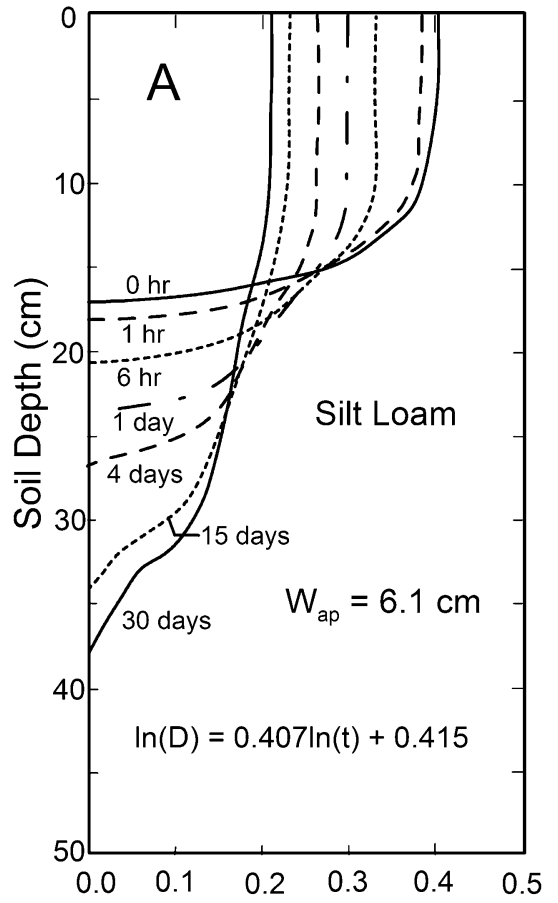

Soil Water Content $\left(\mathrm{gm} / \mathrm{cm}^{3}\right)$

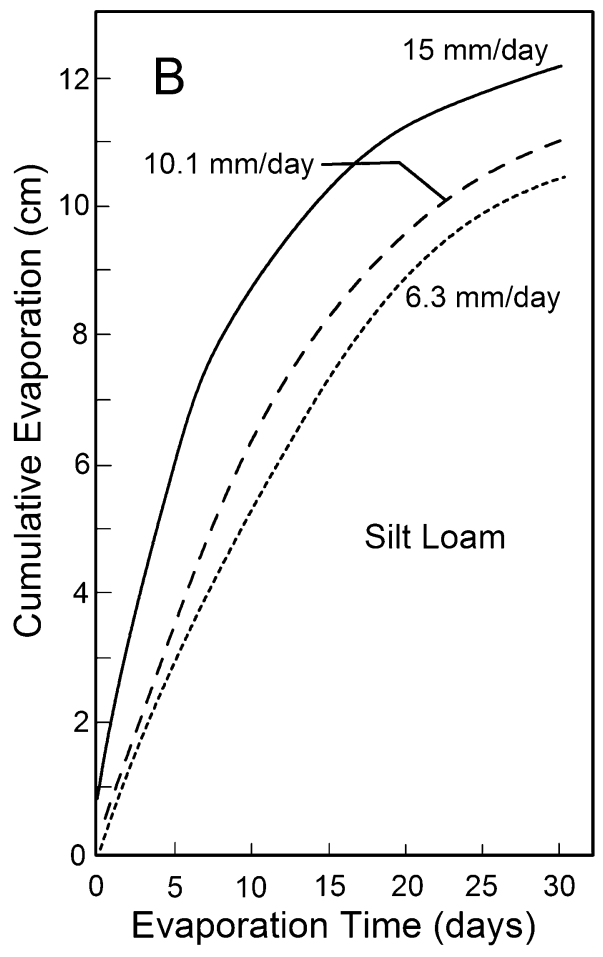

Fig. 3 a Infiltration and percolation of water into silt loam. $W_{\text {ap }}=$ amount of water applied to soil surface. Data are from Biswas et al. (1966). b Cumulative evaporation of soil water as a function of evaporation rate in a silt loam. Data are from Jalota and Prihar (1986) 

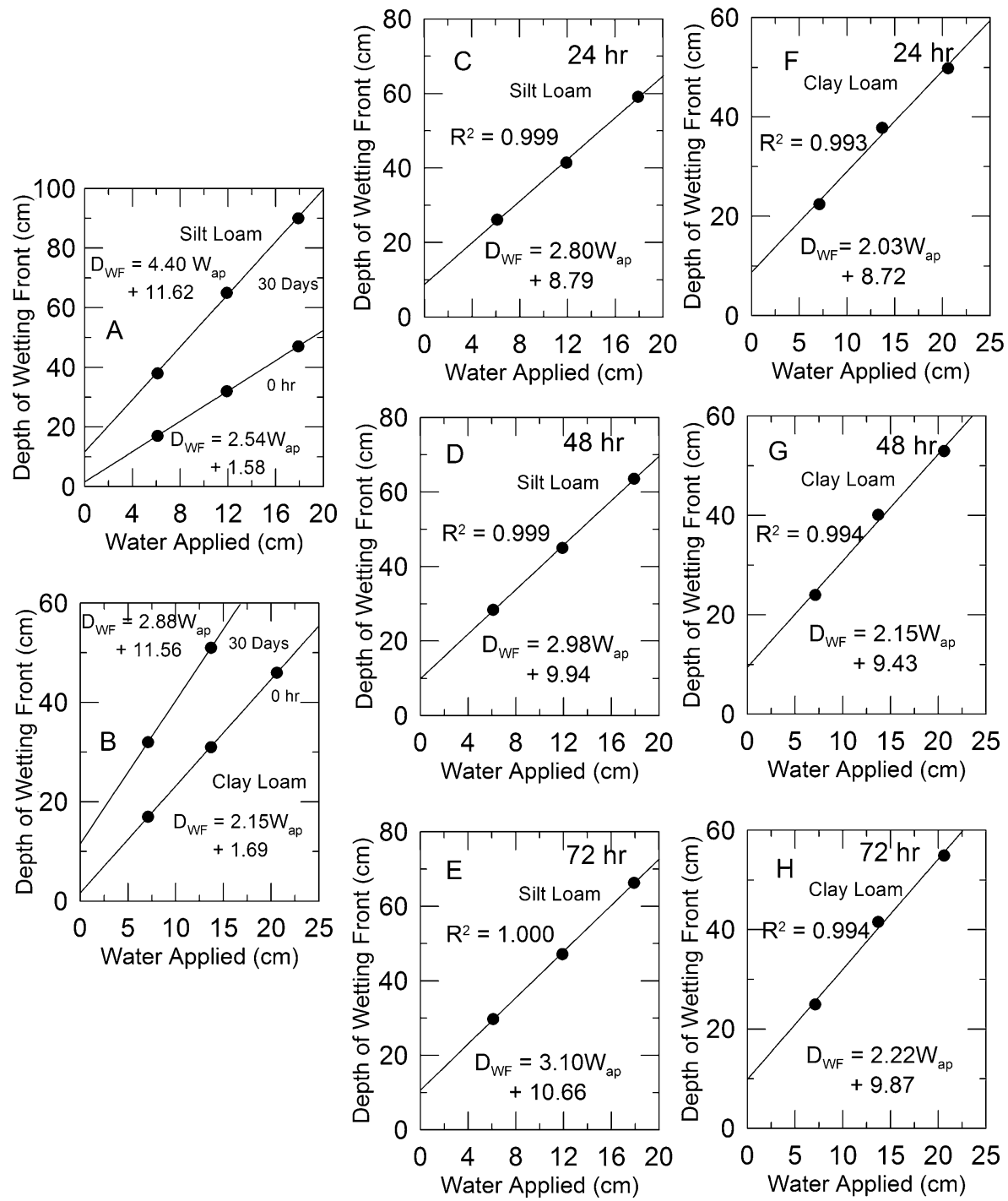

Fig. 4 a-b Extrapolation of the data for water front penetration at $0 \mathrm{~h}$ and 30 days into the silt loam clay loam as a function of the amount of applied water. $\mathbf{c}-\mathbf{h}$ Extrapolation of data for the depth of the wetting front at 24, 48, and $72 \mathrm{~h}$ as a function of water supplied for silt loam and clay loam (data taken from Biswas et al. 1966)

the addition of $0.5,1.0$, and $2.0 \mathrm{~cm}$ of water at time 0 would have resulted in instantaneous penetration depths of $1.8,4.1$, and $6.7 \mathrm{~cm}$ and 30-day penetration depths of $13.8,16.0$, and $20.4 \mathrm{~cm}$. Also shown in Fig. $4 \mathrm{~b}$ are data for infiltration of water into clay loam (Biswas et al. 1966). Note that increasing sediment permeability (silt loam > clay loam) leads to increased penetration depths at both $0 \mathrm{~h}$ and 30 days. Data for the depth of the wetting front as a function of water supplied for silt loam and clay loam are depicted in Fig. 4c-h (data taken from 
Biswas et al. 1966). These data allow us to calculate the depth of the wetting front with time for small amounts $(0.5-2.0 \mathrm{~cm})$ of applied precipitation (Table 1).

\section{Water Use Efficiency and Evapotranspiration}

The water use efficiency (WUE) of a field crop (such as maize) can be defined as

$$
\mathrm{WUE}=\frac{D M}{E T}
$$

where DM is dry matter production and ET is evapotranspiration. The unit of WUE is grams dry matter per kilogram $\mathrm{H}_{2} \mathrm{O}$; the water requirement of a crop is the inverse of WUE (Gardner et al. 1985:92-96). Two papers published in the archaeological literature (Dominguez and Kolm 2005; Muenchrath and Salvador 1995) reference data for the water requirement of maize listed in Table 4.3 of Gardner et al. (1985), that is, $1 \mathrm{~g} \mathrm{DM} / 0.388 \mathrm{~kg} \mathrm{H}_{2} \mathrm{O}$. However, this value is not necessarily applicable to the water requirement for maize grown by prehistoric and early historic Southwestern Native Americans. The fields studied by Gardner et al. (1985) were well watered and most fields farmed by Southwestern Native Americans experienced water stress. Assuming that grain makes up $47.5 \%$ of the dry weight of aboveground maize (Table 2), the 17,000-kg/ha DM yield for the field listed in Table 4.3 of Gardner et al. (1985) equates to $130 \mathrm{bu}$ grain/ac, which implies a planting density of approximately 30,000 plants/ac. This plant density is 15 times that of Southwestern Native American maize fields, and calculations of WUE, using such a plant density, are not applicable to Southwestern maize.

ET in Eq. 0.4 is composed of bare soil evaporation $\left(O_{\mathrm{E}}\right)$ and plant (maize) transpiration $\left(O_{\mathrm{T}, \mathrm{C}}\right) . O_{\mathrm{T}, \mathrm{C}}$ is proportional to the amount of plant dry matter; that is, $\mathrm{C} 4$ plants such as maize have a typical transpiration ratio of $\sim 250$ and that for every molecule of $\mathrm{CO}_{2}$ fixed by photosynthesis, approximately 250 molecules of water are lost (transpired) through the maize's stomata (Taiz and Zeiger 2002:62). Therefore, for each kilogram of $\mathrm{C}$ fixed by maize, $\sim 375 \mathrm{~kg}$ of $\mathrm{H}_{2} \mathrm{O}$ is transpired. Given that, by definition, $1 \mathrm{bu}$ of grain weighs $56 \mathrm{lb}(25.4 \mathrm{~kg})$, that grain makes up $47.5 \%$ of the aboveground plant, and that $43.6 \%$ of the aboveground plant consists of $\mathrm{C}$ (Latshaw and Miller 1924); 8,750 $\mathrm{kg}$ of $\mathrm{H}_{2} \mathrm{O}$ is transpired for every bushel of grain produced.

A Southwestern Native American field that, on average, produces $10 \mathrm{bu} / \mathrm{ac}$ of grain will only transpire $\sim 7.7 \%$ of the water transpired by a field that produces $130 \mathrm{bu} / \mathrm{ac}$ of grain; that is, transpiration is a linear function of plant density. For a 1-ac field, having a surface area of $4,047 \mathrm{~m}^{2}$, the $87,500 \mathrm{~kg}$ of $\mathrm{H}_{2} \mathrm{O}$ transpired by plants producing $10 \mathrm{bu}$ of maize amounts to $2.2 \mathrm{~cm} \mathrm{H}_{2} \mathrm{O}$ transpired from the field. However, the volume of soil $\left(1.51 \mathrm{~m}^{3}\right)$ occupied by each of 440 root systems represented by a cone $^{1}$ with a radius of $1.2 \mathrm{~m}$ and a height of $1.0 \mathrm{~m}$ is only $16 \%$ of the field volume. Therefore, an equivalent depth of $13.4 \mathrm{~cm}$ of water must be supplied from the total root volume to support the transpiration demand of a 10-bu/ac maize crop. Note that

\footnotetext{
${ }^{1}$ Arbuscular mycorrhizal fungi can greatly increase the absorbing surface area of the root, especially in terms of $\mathrm{P}$ adsorption. The fungal hyphae can slightly increase the effective volume of the root cone in that the hyphae can extend between 3 and $7 \mathrm{~cm}$ beyond the $\mathrm{P}$ depletion zone that normally develops within the root cone (Rakshit and Bhadoria 2008).
} 
Table 1 Depth of Wetting Front with Time

\begin{tabular}{|c|c|c|c|c|c|c|}
\hline \multirow[t]{3}{*}{ Soil type } & \multirow[t]{3}{*}{ Wap $(\mathrm{cm})$} & \multicolumn{5}{|c|}{ Time (h) } \\
\hline & & 0 & 24 & 48 & 72 & 720 \\
\hline & & \multicolumn{5}{|c|}{ Depth of Wetting Front $(\mathrm{cm})$} \\
\hline \multirow[t]{3}{*}{ Silt loam } & 0.5 & 2.8 & 10.2 & 11.4 & 12.2 & 13.8 \\
\hline & 1 & 4.1 & 11.6 & 12.9 & 13.8 & 16.0 \\
\hline & 2 & 6.7 & 14.4 & 15.9 & 16.9 & 20.4 \\
\hline \multirow[t]{3}{*}{ Clay loam } & 0.5 & 2.8 & 9.7 & 10.5 & 11.0 & 13.0 \\
\hline & 1 & 3.8 & 10.8 & 11.6 & 12.1 & 16.0 \\
\hline & 2 & 6.0 & 12.8 & 13.7 & 14.3 & 17.3 \\
\hline
\end{tabular}

Wap refers to the amount of water applied to the top of the soil

this value is similar to the minimum amount of summer moisture necessary to produce a crop of maize.

\section{Bare Soil Evaporation}

During the initial stage of infiltration (constant rate stage) when the soil is at near saturation, evaporation rate is controlled by atmospheric conditions (temperature, humidity, and wind speed) in the boundary layer that overlies the soil surface (Hillel 1971). During the second stage of evaporation, the rate of evaporation falls rapidly because vertical transport of water from the soil is governed by the soil's hydraulic properties (Rose 1968) and heat transport (see Fig. 3b for an illustration of the time dependence of evaporation).

Table 2 Individual Plant Aboveground Corn Dry Matter Percentages at Harvest

\begin{tabular}{lccccc}
\hline \% Grain & \% Stover & \% Cob & \% Stover and cob & Total weight $(\mathrm{g})$ & Source \\
\hline 45.9 & 45.9 & 8.2 & 54.1 & 257 & 1 \\
48.0 & 44.5 & 7.5 & 52.0 & & 2 \\
55.0 & 35.5 & 9.5 & 45.0 & & 3 \\
42.6 & 41.0 & 16.4 & 56.4 & 259 & 4 \\
45.1 & 37.3 & 17.5 & 54.9 & 350 & 4 \\
52.0 & 40.8 & 7.2 & 48.0 & $321,250,345$ & 5 \\
47.3 & 42.0 & 10.5 & 52.7 & 341 & 6 \\
49.4 & 39.6 & 11.0 & 50.6 & 373 & 6 \\
42.5 & 47.2 & 10.3 & 57.5 & 264 & 7 \\
AVE=47.5 & 41.5 & 10.9 & 52.4 & 307 & \\
\hline
\end{tabular}

1 Pordesimo et al. (2004), 115 days after planting; 2 Sawyer and Mallarino (2007); 3 D. Westfall (Colorado State University, personal communication, 2008); 4 DiMarco et al. (2007); 5 Shinners and Binversie (2007), 3 years of planting; 6 Hay et al. (1953); 7 Reddy et al. (1991), zero applied N 
About $10 \mathrm{~mm}$ of water can be rapidly evaporated from the surface layer of a silt loam after the layer has been completely wetted (Allen et al. 2005 and references therein). Bare soil evaporation is dependent on several factors including shading, which reduces evaporation $\left(O_{\mathrm{E}}\right)$. Maize hills in Southwestern Native American fields are usually spaced about $3 \mathrm{~m}$ apart, whereas Midwestern farmers favor a row spacing of $\sim 0.75 \mathrm{~m}$, which implies a hill spacing of $\sim 18 \mathrm{~cm}$ along a row, given a plant density of 32,000 plants/ac (Farnham 2001).

Early historic maize plant densities imply that only $\sim 11 \%$ of the soil surface will be shaded by maize at noon; thus, bare soil evaporation will be relatively high under these conditions. Given that semiarid regions such as the American Southwest experience free-surface evaporation rates ranging from 5 to $8 \mathrm{~mm} /$ day (Abdul-Jabbar et al. 1983; Fig. 2 in Benson and White 1994), it follows that water will be removed from the saturated soil surface layer within a few days following the precipitation event during the growing season.

The leaf area index (LAI) is the ratio of the total one-sided leaf area of a plant divided by the surface area of ground covered by the plant. From seedling emergence to flowering, the maize canopy will develop a LAI of 3-5 (Westgate et al. 2004). If we assume an effective canopy radius of $0.5 \mathrm{~m}$, then Midwestern maize will shade nearly $100 \%$ of the bare ground area beneath its canopy. In the Shandong province of China, maize grown at a plant density sufficient to produce $103 \mathrm{bu} / \mathrm{ac}$ was shown to capture 94\% of the incident solar radiation (Odend'hal 1993). Also, shading by maize canopy planted at a density of 1 plant $/ 4 \mathrm{~m}^{2}$ under dryland conditions reduced evaporation by $20-30 \%$ in a 2 -year experiment conducted by Todd et al. (1991). Increased shading also decreases the potential for weeds by preventing sunlight from reaching their leaves (Johnson et al. 1998).

\section{The Amount of Water Stored in Maize}

The amount of water contained within maize $\left(O_{\mathrm{C}}\right)$ at any point in time is a small fraction of the water transpired. Shinners and Binversie (2007) showed that after $\sim 150$ days, the ratio of stover moisture to grain moisture plateaus at a value of 2.1 and that grain moisture at 150 days is 33\%. Before drying, a bushel of grain weighs $37.9 \mathrm{~kg}$ and contains $12.5 \mathrm{~kg}$ of $\mathrm{H}_{2} \mathrm{O}$. The stover dry matter associated with the wet grain weighs $28.1 \mathrm{~kg}$. At its original $69.3 \%$ moisture content, the stover weighs $91.5 \mathrm{~kg}$ and contains $63.4 \mathrm{~kg}$ of $\mathrm{H}_{2} \mathrm{O}$. Thus, the aboveground plant associated with $10 \mathrm{bu}$ of maize contains $634 \mathrm{~kg}$ of $\mathrm{H}_{2} \mathrm{O}$, which is only $5.5 \%$ of the amount of water transpired during the growth of maize.

\section{Soil Structure and Water Retention}

The structure of the soil profile is important in terms of water retention. Dominguez and Kolm (2005) have presented an excellent summary of soil textures that influence the hydraulic characteristics of a soil. Sand, clay, and silt (the primary textural components of soil) have volumetric water contents of $0.43,0.38$, and $0.45 \mathrm{~cm} \mathrm{H}_{2} \mathrm{O} / \mathrm{cm}$ dry soil and field capacities of $0.05,0.36$, and $0.21 \mathrm{~g} \mathrm{H}_{2} \mathrm{O} / \mathrm{g}$ dry soil. It follows that a soil profile consisting solely of sand will drain quickly and plant roots will not be able to extract much water from such a porous soil. A soil consisting only of clay can retain a 
large volume of water; however, little of the water is available to plants given its low hydraulic conductivity. However, a soil consisting solely of silt has a relatively high porosity but tends to drain rather slowly, allowing plant roots to access the water. Fields whose soil profiles are characterized by coarse-textured surface layers underlain by fine-grained clayey horizons favor the production of maize in that the clayey layer holds water in the root zone (Bradfield 1971; Hack 1942; Homburg 2000; Sandor 1995).

\section{Solar Radiation and its Proxies}

The growth of maize is directly related to the amount of solar radiation absorbed by the plant. According to Lindquist et al. (2005), "Dry matter production by maize depends on the total carbon (C) fixed by photosynthesis and the fraction of that $\mathrm{C}$ converted to dry matter (Norman and Arkebauer 1991)...and... plant dry matter accumulation is related to the amount of radiation absorbed by the plant canopy (e.g., Monteith 1977)."

\section{RUE and Photosynthetically Active Radiation}

Radiation use efficiency describes the relationship between intercepted radiation and dry matter production and is expressed in grams per megajoule (Monteith 1977). Radiation interception is a function of the LAI and the extinction coefficient which measures the efficiency of radiation interception. LAI increases over time, reaching a maximum value approximately 2 months after sowing when male flowering and pollen shed begins (Lindquist et al. 2005). At this time, the fraction of intercepted photosynthetically active radiation reaches a maximum and then plateaus.

Photosynthetically active radiation makes up about $50 \%$ of total solar radiation (Sinclair and Muchow 1999). Müller (2001) demonstrated that the leaves of maize absorb $92 \%$ of the radiation that intercepts the canopy, and Muchow et al. (1990) have shown that temperature affects growth duration by controlling the length of time that a crop can intercept radiation. Lindquist et al. (2005) measured maize growth under optimal conditions in Nebraska and showed that maize aboveground biomass accumulated as a linear function of absorbed photosynthetically active radiation (APAR); that is, radiation use efficiency (RUE) is a constant during the growth of the maize.

As mentioned previously, Native American maize was planted at a density of 440 hills/ac, each hill averaging 4.5 plants. Multiple plants per hill results in a much higher LAI for the set of plants and may cause self-shading of some fraction of the combined leaf surface at solar noon; however, the wide spacing of the hills allows sufficient light interception before and after solar noon such that the plants are not radiation limited.

\section{Solar Radiation Proxies}

Unfortunately, solar radiation measurements are lacking for most of the study area so other meteorological data must be used to proxy for APAR, that is, freeze-free days (FFD) and growing degree days (GDD). 
Most varieties of maize, including Southwest Native American landraces such as Hopi blue maize and a variety of Zuni cultivars, require about 120 FFD (Bradfield 1971; Muenchrath et al. 2002). The 120 days refers to the time from emergence to black layer formation which indicates physiological maturity (D. Westfall, Colorado State University, 2010, personal communication). In a recent experimental maize grow-out in the Durango District of southwestern Colorado, Bellorado (2007) showed that five southwestern Native American maize varieties reached maturity within 1,055-1,110 GDD, which are calculated using the following formula:

$$
\mathrm{GDD}=\sum_{i=m}^{n}\left(T_{\mathrm{a}}-T_{b}\right) \Delta t,
$$

where $T_{\mathrm{a}}$ is the average daily temperature in degree Celsius, $T_{\mathrm{b}}$ is a base temperature $\left(10^{\circ} \mathrm{C}\right)$ below which development is assumed to cease, $m$ is the date of the first freeze-free day after planting, $n$ is the date of the last freeze-free day, and $t$ is a time step in days. If $T_{\mathrm{a}}>30^{\circ} \mathrm{C}, T_{\mathrm{a}}$ is set to $30^{\circ} \mathrm{C}$. For the purposes of this paper, we will follow the results of Bellorado (2007) and adopt 1,000 GDD as the value below which maize yields cease to be optimal.

\section{Soil Chemistry and Maize Production}

In the semiarid Southwest, several soil chemistry parameters, including $\mathrm{N}$, phosphorous $(\mathrm{P})$, salinity, and $\mathrm{pH}$, are important in terms of maize production.

\section{Carbon and Nitrogen}

Decomposition of dead organic matter, including dead plant material (litter), releases nutrients to the soil that are necessary for plant and microbial production. Decomposition consists of three processes-leaching, fragmentation, and chemical alteration (Chapin et al. 2002).

Leaching removes water-soluble inorganic and organic chemical species from litter, including simple carbohydrates and amino acids that can be absorbed by soil microbes. Animals (including protozoa) are primarily responsible for the fragmentation of litter; however, both freeze-thaw and wet-dry cycling can destroy litter's cellular integrity. In general, fragmentation disrupts cell walls and makes labile cell nutrients available to the microbial community. Microfauna such as nematodes and protozoa not only fragment and transform soil organic matter (SOM) but also consume bacteria, releasing mineralized $\mathrm{N}$ to the soil zone.

Fungi and bacteria are responsible for most of the chemical alteration of plant litter. Fungi are the principal initial decomposers of dead plant material; they secrete enzymes capable of breaking down all classes of plant compounds, including highly refractory lignin (Jastrow et al. 2007). Whereas fungi are the principal decomposers of fresh plant litter that resides on the soil surface, bacteria dominate decomposition processes in the rhizosphere (the volume of soil influenced by plant roots). Roots via their exudations and decomposition also act to introduce organic carbon within the soil zone.

Organic C is abundant within the rhizosphere (Norton and Firestone 1991) where roots excrete carbohydrates (Jaeger et al. 1999); therefore, bacteria that populate the rhizosphere are limited by the availability of nutrients other than C. Such nutrients 
become available when the bacteria break down SOM, releasing ammonium $\left(\mathrm{NH}_{4}{ }^{+}\right)$ to the soil. In addition, protozoa graze the bacterial populations, mineralizing $\mathrm{N}$ in the process (Clarholm 1985). As a result, the rate of $\mathrm{N}$ mineralization within the rhizosphere is much greater $(\sim 30 \%)$ than in the bulk soil.

Elevated temperatures increase the activity of the microbial community in relatively wet regions, increasing the mineralization rate of organic $\mathrm{C}$ (Lloyd and Taylor 1994); however, in semiarid climates, increasing temperature dries the soil and reduces the decomposition rate of SOM. Soil microbes also suffer in semiarid environments under conditions of low soil moisture and high salinity. Under such conditions, osmotic gradients cause microbial cell walls to burst.

As SOM is decomposed, dissolved organic nitrogen (DON) is released. When microbial production is carbon limited, microbes use carbon associated with the DON to support growth and respiration, releasing $\mathrm{NH}_{4}{ }^{+}$into the soil as a waste product ( $\mathrm{N}$ mineralization). Nitrifying bacteria transform $\mathrm{NH}_{4}{ }^{+}$first to $\mathrm{NO}_{2}{ }^{-}$and then to $\mathrm{NO}_{3}{ }^{-}$(nitrification). Both $\mathrm{NH}_{4}{ }^{+}$and $\mathrm{NO}_{3}{ }^{-}$can be absorbed by plants and microbes; however, the negatively charged $\mathrm{NO}_{3}{ }^{-}$is highly mobile and can move rapidly through the soil zone within the percolating aqueous phase. Greater soil moisture translates into enhanced rates of microbial activity (Hoeft and Peck 2002; Williams et al. 2000); for example, in one field experiment carried out in Rush Valley, Nevada, a 25-mm precipitation event increased $\mathrm{C}$ mineralization rates by $50 \%$, microbial biomass $\mathrm{C}$ by $150 \%$, and reduced soluble organic $\mathrm{C}$ and $\mathrm{N}$ concentrations by 50\% (Hooker and Stark 2008).

SOM resists decomposition via biochemical recalcitrance, chemical stabilization, and physical protection (Jastrow and Miller 1998). According to Herrmann (2003), simple compounds such as sugars and protein are first to decompose. SOM that contains lignin derivates or melanin produced by fungi is more difficult to decompose and is biochemically recalcitrant (Martin and Haider 1986; Stott et al. 1983). Chemical stabilization occurs when organic matter is adsorbed onto clay or other mineral surfaces (Swift et al. 1979). Physical protection occurs when organic matter becomes sterically isolated from microorganisms.

There exists an indefinite number of pools of soil organic carbon (SOC) and organic $\mathrm{N}$ within any particular soil zone, each operationally characterized by a different rate of decomposition (mineralization). Different groups of researchers have used different numbers of SOC pools to describe the overall process of SOC decomposition; for example, Jenkinson and Rayner (1977) modeled the decomposition of SOC using five pools, each having a different half-life, whereas Parton et al. (1993) and Paul et al. (1995) adopted three SOC pools. Numerous researchers have used two pools to describe SOC decomposition (e.g., Harrison et al. 1993; Hsieh 1993), and some researchers have treated SOC decomposition, assuming there is only one pool (e.g., Clay et al. 2007). In these studies, the decomposition/decay of the individual SOM pools have been modeled using firstorder kinetics, i.e.,

$$
C=C_{0} e^{-\left(0.693 t / t_{1 / 2}\right)}
$$

where $C$ is the concentration of SOC at any time $t$ in a particular SOC pool, $C_{0}$ is the initial concentration of SOC in a particular pool, and $t_{1 / 2}$ is the half-life of the 
decomposing SOC pool. In natural systems, decomposition of SOC is a function of soil moisture, soil temperature, and other soil chemical and physical parameters (see, e.g., Leirós et al. 1999); therefore, in an environmental context, decomposition of individual SOC pools is actually not associated with a constant half-life. Why then can a soil containing an indefinite number of SOC pools, each with a different decomposition rate, be modeled using a finite range of pool values each having a specific half-life? Figure 5 suggests an answer to that question. In this example, the decomposition histories of three pools of SOC having initial concentrations of $60 \%, 30 \%$, and $10 \%$ and having half-lives of 5, 2, and 1 year (s) have been idealized. The total residual SOC obtained by summing the three decomposition curves over time is shown in Fig. 5 as a dashed line. Note that an exponential function can be fit (howbeit imperfectly) to the residual SOC curve. This suggests that although the sum of a set of exponential functions does not yield an exponential function, the sum can be "adequately" fit with an exponential function. In fact, the decomposition of individual SOC pools is not characterized by a constant half-life; however, pool decay can be modeled to a greater or lesser degree assuming a constant half-life.

Physical and chemical fractionation techniques have been used to define and lump different SOC pools in terms of their relative rate of mineralization. It appears that most researchers divide the SOC pools into labile (readily degradable) and refractory (non-degradable) fractions with occasional consideration of a fraction of intermediate degradability. Post and Kwon (2000) have suggested that the labile fraction is light-fraction organic carbon contained within particulate plant and animal residues that is highly decomposable (Boone 1994). Generally speaking, the light fraction has bulk turnover times ranging from months to a few years. The majority of SOC is associated with clay-sized $(<4 \mu \mathrm{m})$ minerals and consists of heavy-fraction organomineral complexes (Post and Kwon 2000). Turnover times of this fraction are

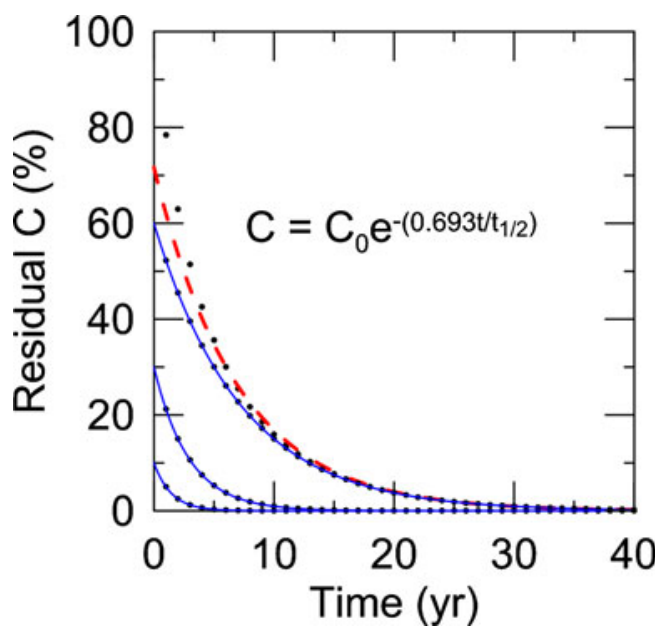

Fig. 5 Hypothetical exponential decomposition of three pools of SOC with time. The three pools of SOC have initial concentrations of $60 \%, 30 \%$, and $10 \%$, and half-lives of 5, 2, and 1 year(s). Note that total residual organic carbon as a function of time can be fit with a negative exponential (dashed line) 
on the order of decades. Most models of SOC turnover also introduce a pool of refractory carbon with turnover times of a millennium or two (Parton et al. 1988; Jenkinson 1990). The refractory pool is thought to contain a nearly inert lightfraction component (e.g., charcoal) and some very refractory, heavy-fraction organomineral components.

Parton et al. (1993) have suggested a somewhat different makeup of the three fractions; that is, the labile fraction consists of live soil microbes plus microbial products, the intermediate pool consists of resistant plant material (e.g., lignin and soil-stabilized plant and microbial materials), and the refractory fraction consists of physically and chemically stabilized SOM.

One simple way to rapidly distinguish between labile and refractory SOC is to hydrolyze SOC using boiling $6 \mathrm{~N} \mathrm{HCl}$ (e.g., Martel and Paul 1974; Silveira et al. 2008). The acid hydrolysis effectively dissolves the young labile carbon compounds, leaving older more refractory carbon compounds in the residue. The ${ }^{14} \mathrm{C}$ age of the residual carbon generally increases with depth in a soil profile, whereas the amount of total SOC generally decreases continuously with depth (Paul et al. 1997, 2001; Fig. 6). Note also that the non-hydrolyzable SOC fraction of the archived (19471949) prairie soils studied by Paul et al. (1997) makes up between $40 \%$ and $55 \%$ of total SOC. It is not clear why the hydrolyzable fraction remains relatively constant with depth. This contrasts with a simple model of the evolution of labile and refractory SOC pools; that is, one would expect the labile SOC and organic N pools to decay exponentially with a rapid rate constant and the refractory SOC and organic $\mathrm{N}$ pools to decay exponentially with a much slower rate constant such that the fraction of refractory SOC and organic $\mathrm{N}$ increase with depth (Fig. 7). One explanation is that labile SOC and organic $\mathrm{N}$ were contributed to the soil at depth by modern roots and root exudates, in the Paul et al. (1997) study. In addition, dissolved organic carbon (DOC), which is a labile form of SOC, is free to move downward in the soil zone. The DOC can become attached to mineral surfaces and become
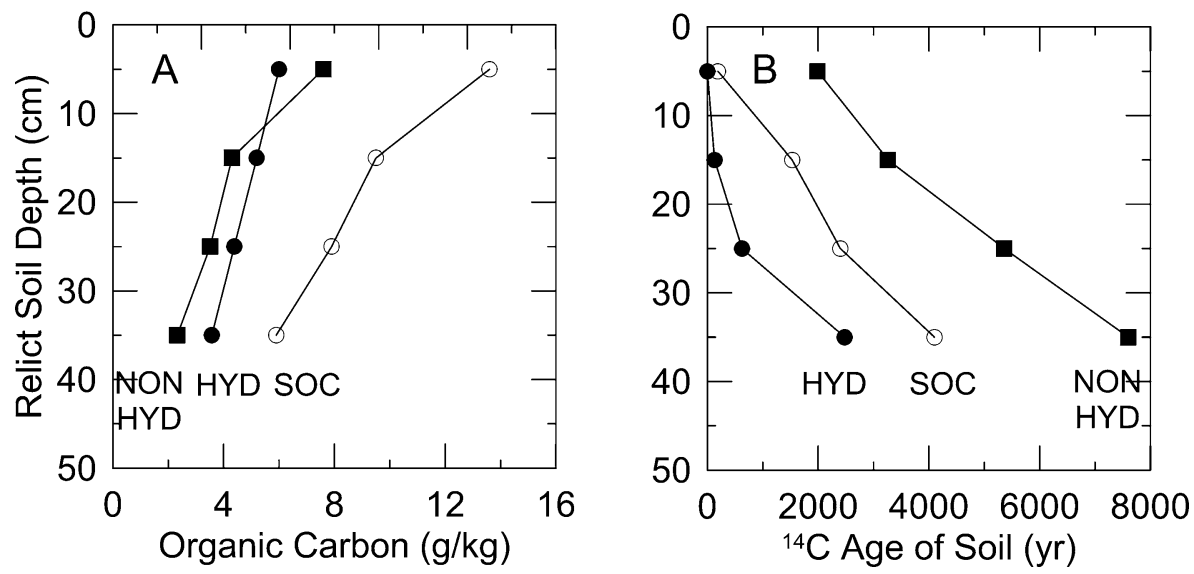

Fig. 6 a Amounts of total soil organic carbon (SOC), hydrolyzable (HYD) organic carbon, and nonhydrolyzable $(N O N H Y D)$ organic carbon in Akron, Colorado, soils. b ${ }^{14} \mathrm{C}$ ages of the same soils. This figure is based on data from Paul et al. (1997) 


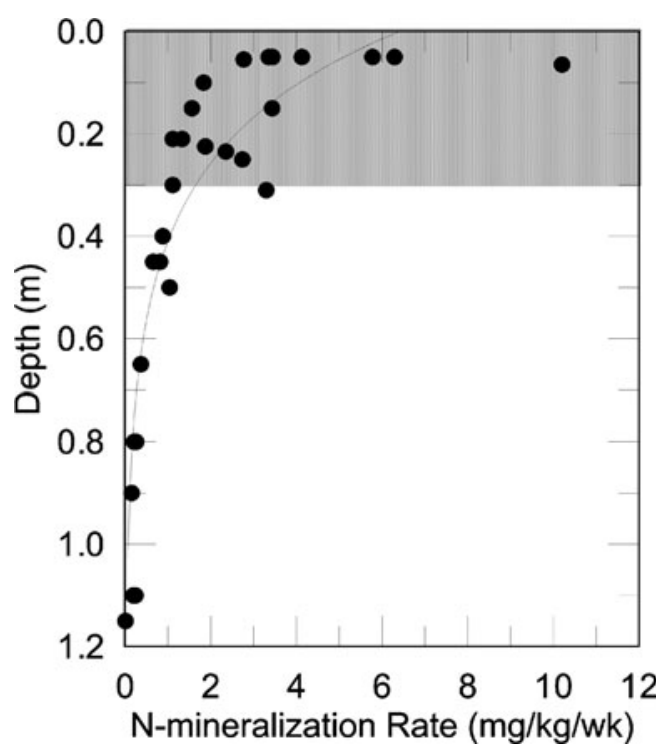

Fig. 7 Change in the $\mathrm{N}$ mineralization rate with depth in semiarid Moroccan soils (data from incubations experiments in Soudi et al. (1990). Shaded area indicates depth range over which highest N mineralization rates occur. Note that $\mathrm{N}$ mineralization rate is a proxy for $\mathrm{C}$ mineralization rate

resistant to degradation. Addition of $6 \mathrm{~N} \mathrm{HCL}$ probably freed the DOC from mineral surfaces, transforming it into labile SOC in the Paul et al. (1997) study. Thus, the addition of $6 \mathrm{~N}$ HCL transforms some organomineral SOC into "apparently" labile SOC at depth. Differences in the ${ }^{14} \mathrm{C}$ age distributions of the hydrolyzed and nonhydrolyzed SOC fractions support the existence of one or both of these processes; that is, the ${ }^{14} \mathrm{C}$ age of the hydrolyzed component is substantially younger than the ${ }^{14} \mathrm{C}$ age of the non-hydrolyzed component in the prairie soil and the difference between the paired ages increases with depth either in response to a decrease in rooting density with depth and/or to continuous sorption of DOC along the vertical flow path (Fig. 6b).

Optimum microbial activity occurs when the SOM C/N ratio is about 25:1 (Myrold 1998). If the ratio exceeds 25:1, then $\mathrm{N}$ availability limits biological activity and $\mathrm{N}$ may become immobilized in the microbial biomass. During the late stages of $\mathrm{N}$ mineralization, lignin and its breakdown products can condense with organic $\mathrm{N}$ to form highly stable organic $\mathrm{N}$, thereby reducing net $\mathrm{N}$ mineralization (Berg et al. 2001).

The point of the previous discussion, with respect to this study, is that a substantial amount of the SOC and organic $\mathrm{N}$ within the SOC is not amenable to rapid mineralization. Unfortunately, most mineralization rate studies have been done using laboratory incubation techniques (see, e.g., Zou et al. 2005) which are not easily relatable to field mineralization rates; for example, Rasmussen et al. (1998) compared laboratory and field-based $\mathrm{N}$ mineralization rates and showed that laboratory incubations do not accurately reflect $\mathrm{N}$ mineralization in the field.

In general, organic $\mathrm{C}$ turnover rates estimated from long-term incubations are significantly different from field turnover rates, owing to the rapid decline in soil 
microbial biomass during incubation (Fang et al. 2005). Thus, the first-order kinetic data resulting from these experiments, while useful in defining different pools of $\mathrm{SOM}$, are not useful in the calculation of agricultural field life, for example, change in the amounts of organic $\mathrm{N}$ and available $\mathrm{NO}_{3}-\mathrm{N}$ over time. Incubation experiments are, however, valuable in assessing relative changes in $\mathrm{N}$ mineralization rates with depth; for example, Soudi et al. (1990) used incubation methods to measure N mineralization rates of eight semiarid Moroccan soils as a function of depth. The data indicate an exponential decrease in $\mathrm{N}$ mineralization rate with depth and serve to demonstrate that most of the $\mathrm{N}$ mineralization occurs in the upper $20-30 \mathrm{~cm}$ of soil (Fig. 7).

Soils in semiarid environments are often deficient in N (Ludwig 1987; Nabhan 1984; Sandor and Gersper 1988; West 1991). Herrmann (2003) has stated that in general, "Gross nitrogen mineralization is proportional to $\mathrm{C}$ mineralization in soils, so that $\mathrm{C}$ mineralization may be used as a predictor for gross $\mathrm{N}$ mineralization."

A mean $\mathrm{N}$ mineralization rate is not necessarily applicable to any 1 year because organic matter mineralization is a function of available soil moisture which is highly variable (Hoeft and Peck 2002), especially in the Southwest. However, mean mineralization values should be applicable when averaged over decades.

The range of $\mathrm{N}$ mineralization rates $(1.5-3.5 \% / \mathrm{year})$ reported in the literature (e.g., Below 2002; Brady and Weil 2008:547) probably refers to mineralization processes within the plow zone (surface $30 \mathrm{~cm}$ of soil) in relatively humid environments where $\mathrm{N}$ fertilizer has been added. This zone contains most of the available labile organic $\mathrm{C}$ and organic $\mathrm{N}$, which tends to mineralize rather quickly. Therefore, these values may not be appropriate to older soils lower in the soil column. If a field dedicated to the cultivation of maize is not supplied with organic matter, over time, labile pools of SOC and organic $\mathrm{N}$ become exhausted, leaving refractory $\mathrm{C}$ and $\mathrm{N}$ compounds. This results in very low $\mathrm{N}$ mineralization rates.

There are three studies that illustrate this principal. Clay et al. (2007) have shown that at a South Dakota research site, SOC within the 0 - to 15 -cm depth in fine loamy sand decreased from 26.8 to $24.0 \mathrm{~g} / \mathrm{kg}$ between 2000 and 2005. Clay et al. (2007) have also shown that SOC in the surface $30 \mathrm{~cm}$ of a Minnesota silt loam decreased from 90.8 to $77.9 \mathrm{Mg}$ /ha and from 77.9 to $73.2 \mathrm{Mg} / \mathrm{ha}$ from 1980 until 1993 and from 1993 to 2002. In both areas, plant growth was prevented by routine cultivation. In another field experiment, undisturbed silty clay-loam soils in Rothamsted, England were kept bare by hand weeding between 1870 and 1970. During that time period, SOC decreased from 38 to 21 tons/ha in the top $23 \mathrm{~cm}$ of soil (Jenkinson and Rayner 1977).

The following equation can be used to calculate $k$ (the organic $\mathrm{N}$ or $\mathrm{C}$ mineralization rate constant), where $t$ is the time (year) elapsed between measurements of SOC, i.e., $t$ between measurement of $C_{\mathrm{o}}$ and $C$ :

$$
\ln \left[\frac{C}{C_{o}}\right] / t=k
$$

For the South Dakota site, the SOC mineralization rate between 2000 and 2005 was $2.2 \%$ year. For the Minnesota field, the SOC mineralization rate between 1980 and 1993 was 1.2\%/year, and between 1993 and 2002, it had decreased to $0.69 \% /$ year. In the case of the Rothamsted soil, the SOC mineralization rate was found to be 
$0.59 \% / y e a r$. If we assume that the $\mathrm{N}$ mineralization and SOC mineralization rates have roughly the same values, these studies demonstrate that the $\mathrm{N}$ mineralization rate decreases substantially over time in fields that do not receive inputs of organic $\mathrm{C}$ and $\mathrm{N}$.

The overall mass balance equation describing $\mathrm{N}$ gain and loss from a soil is

$$
N_{M I N}=N_{C O R N}+N_{S T O R}+N_{L O S T}
$$

where available $\left(N_{\mathrm{MIN}}\right)$, the amount of mineralized $N$, is the sum of $\left(N_{\mathrm{CORN}}\right)$, the amount of $\mathrm{NO}_{3}-\mathrm{N}$ consumed by the plant, $\left(N_{\mathrm{STOR}}\right)$, the amount of $\mathrm{NO}_{3}-\mathrm{N}$ temporarily stored in the soil zone, and $N_{\mathrm{LOST}}$, the amount of $\mathrm{NO}_{3}-\mathrm{N}$ lost from the soil zone. In subsequent calculations of available $\mathrm{N}, N_{\mathrm{MIN}}$ is calculated using

$$
N_{\text {MIN }}(t)=1-N_{0} e^{-m t}
$$

where $N_{\mathrm{MIN}}(t)$, the amount of $\mathrm{N}$ mineralized at time step $t$, is equal to the initial amount of organic $\mathrm{N}\left(N_{0}\right)$ in the $1.51-\mathrm{m}^{3}$ root cone and $m$ is the $\mathrm{N}$ mineralization rate. The amount of stored $\mathrm{NO}_{3}-\mathrm{N}$ is given by

$$
N_{S T O}(t)=\left(N_{M I N}(t)+N_{S T O}(t-1)-N_{E X T}(t)\right) \times F_{S T O}(t)
$$

where $N_{\mathrm{STO}}(t-1)$ is the amount of $\mathrm{N}$ stored in the previous time step, $N_{\mathrm{EXT}}(t)$ is the amount of $\mathrm{N}$ extracted by aboveground maize, and $F_{\mathrm{STO}}(t)$ is the fraction of mineralized $\mathrm{N}$ stored in the current time step, that is, the amount that survives the loss of $\mathrm{NO}_{3}-\mathrm{N}$ from a 1-m-deep soil zone.

Part of the stored $\mathrm{N}$ is contained within the previous crop's root mass. Machinet et al. (2009) have shown that the $\mathrm{N}$ concentration in the dry matter of six maize genotypes ranged from $0.8 \%$ to $1.4 \%$, averaging $1.0 \pm 0.2 \% \mathrm{~N}$, and data from Shinners and Binversie (2007) and Fehrenbacher and Rust (1956) indicate that the root mass is about $14 \%$ of the mass of the aboveground plant. In a prehistoric Native American 1-ac field with 2,000 plants and 440 hills, each hill containing 4.5 plants, aboveground plants in a single hill weigh 1,382 $\mathrm{g}$ (Table 2). Therefore, the root mass associated with each hill weighs $193 \mathrm{~g}$ and contains $1.93 \mathrm{~g}$ of $\mathrm{N}$, and the root mass in all 440 hills contains about $850 \mathrm{~g} \mathrm{~N}$.

In a field experiment in which maize roots were dried, ground to pass a $0.5-\mathrm{mm}$ sieve, and placed in nylon mesh bags $10 \mathrm{~cm}$ below the soil surface, $50 \%$ of the root mass was lost in the first 6 months and $10 \%$ of the root mass was lost during the next 6 months (Zibilske and Materon 2005). A projection of the rate of mass loss suggests that all the root mass would have decomposed within 3 years, releasing all stored $\mathrm{N}$ to the soil zone.

\section{Nitrogen, Phosphorous, and $\mathrm{pH}$}

$\mathrm{N}$ availability is greatest within a $\mathrm{pH}$ range of 6.0-8.0 (Foth and Ellis 1988), and $\mathrm{P}$ availability is greatest within a $\mathrm{pH}$ range of 6.0-6.5 (Tisdale et al. 1985). Elevated soil $\mathrm{pH}$ values favor the formation of insoluble phosphate minerals such as hydroxyapatite $\left(\mathrm{Ca}_{10}\left[\mathrm{PO}_{4}\right]_{6}[\mathrm{OH}]_{2}\right)$, which limit the amount of phosphate ion $\left(\mathrm{PO}_{4}{ }^{3-}\right)$ released to the solution. It follows that maize yields are optimal when soil $\mathrm{pH}$ is between 6.0 and 6.5 . 


\section{Salinity}

Salinity (electrical conductivity) measurements are usually made when dealing with irrigation water; however, the salinity of soil-water associated with dryland settings also is important. The increased concentration of dissolved solids in soil water makes it more difficult for plants roots to extract water from the soil, increasing the value of the permanent wilting point, thereby decreasing the amount of plantavailable water.

In terms of soil--water recharge, it is necessary for some water to percolate below root depth from time to time or salts will accumulate, increasing soil salinity, which decreases maize yields. A plot of relative maize yields versus soil-water conductivity (Fig. 8) indicates that when conductivity exceeds about $1.5 \mathrm{dS} / \mathrm{m}$, maize yields begin to decline (Ayers 1977).

\section{Scaling Midwestern Nutrient Indicators $\mathrm{NO}_{3}-\mathrm{N}$ and Available $\mathrm{P}$}

Midwestern fields are planted at a density of $\sim 32,000$ plants/ac, whereas early historic Southwestern fields were planted at a density of approximately 2,000 plants/ ac. If the distance between Midwestern maize rows is set to $1 \mathrm{~m}$, then the distance between plants in a row is $12.5 \mathrm{~cm}$. Obviously, such a high planting density puts a great demand on soil nutrients relative to the Southwestern practice of planting four to five plants on hills spaced $3 \mathrm{~m}$ apart; that is, the stover and grain in 32,000 plants remove $105 \mathrm{~kg}$ of $\mathrm{N}$ from the soil each year.

The addition of $\mathrm{P}$ and $\mathrm{NO}_{3}-\mathrm{N}$ (in the form of urea or ammonium nitrate) fertilizers is a common practice in the Corn Belt. The application of inorganic forms of $\mathrm{N}$ fertilizer began accelerating in 1945 (Thompson 1969), and today, the Iowa Cooperative Extension Service recommends that between 70 and $90 \mathrm{~kg} \mathrm{~N}$ per acre

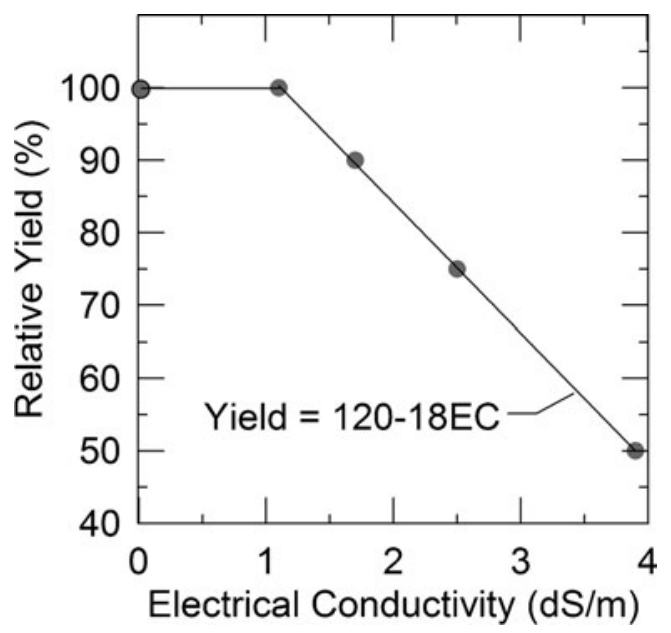

Fig. 8 Relative maize yields as a function of salinity (data from Ayers 1977) 
be applied if all $\mathrm{N}$ is supplied before crop emergence (Blackmer et al. 1997; Fig. 9). Somewhat more detailed calculations for the addition of $\mathrm{N}$ fertilizer that account for $\mathrm{N}$ credits have been produced by the University of Nebraska and reported in Mortvedt et al. (2007).

$N_{F}=0.454 \times\left[35+(1.2 \times Y)-\left(8 \times N O_{3}\right)-\left(0.14 \times Y \times\{(1.80 \times \% O C)+0.35\}-N_{C}\right.\right.$

where $N_{\mathrm{F}}$, the $\mathrm{N}$ fertilization rate $(\mathrm{kg} / \mathrm{ac})$, is a function of maize yield $Y(\mathrm{bu} / \mathrm{ac})$, the soil's $\mathrm{NO}_{3}$ concentration $(\mu \mathrm{g} / \mathrm{g}$ ), the soil's SOM (which we have expressed in terms of the organic carbon percent (\%OC), using a relationship developed by Ranney 1969 ), and other $\mathrm{N}$ credits $\left(\mathrm{N}_{\mathrm{C}}\right)$, e.g., addition of $\mathrm{NO}_{3}$-containing irrigation water.

If we apply Eq. 1.1 to fields in Logan County, Illinois, which average 1.04\% organic C in the upper $1 \mathrm{~m}$ of soil (U.S. Department of Agriculture 2009 data for seven soil profiles), we find that if these Midwestern fields are depleted in $\mathrm{NO}_{3}-\mathrm{N}$, approximately $80 \mathrm{~kg} \mathrm{~N}$ per acre should be added to the fields. On the other hand, if soil $\mathrm{NO}_{3}-\mathrm{N}$ exceeds $20 \mu \mathrm{g} / \mathrm{g}$, then $\mathrm{N}$ fertilization is unnecessary (Table 3 ). The effect of $\mathrm{N}$ treatment on grain and stover yields is illustrated for fields in southeastern North Dakota in Fig. 9 (Derby et al. 2005).

As will be discussed in the following sections, Midwestern agronomists have developed simple methods for assessing the nutrient status of a maize field based on available $\mathrm{NO}_{3}-\mathrm{N}$ and extractable P. Given the lower plant densities associated with Southwestern Native American fields, is there a way to roughly scale such nutrient measures so they can be applied to Southwestern Native American fields?

One approach is to assume that the nutrient requirement is a simple function of plant density; that is, Native American fields need only 2,000/32,000 or $6.25 \%$ of the nutrient loading required by Midwestern field systems. Unfortunately, this approach does not account for differences in planting patterns. While it is true that the aboveground plant represents the principal nutrient sink, the crop as a whole

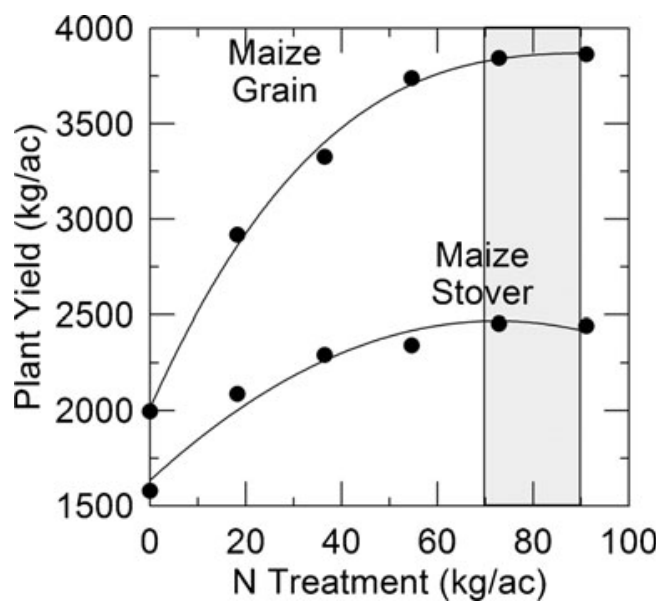

Fig. 9 Grain and stover (plant biomass minus grain and root biomass) yields as a function of the amount of $\mathrm{N}$ added (data from Derby et al. 2005) 
Table 3 Fertilization Rates for Southwestern and Midwestern Fields

\begin{tabular}{lccc}
\hline $\mathrm{N}_{\mathrm{F}}(\mathrm{kg} / \mathrm{ac})$ & $\mathrm{NO}_{3}(\mathrm{ug} / \mathrm{g})$ & OC $(\%)$ & $Y(\mathrm{bu} / \mathrm{ac})$ \\
\hline Southwestern fields & & & \\
20 & 0 & 0.63 & 10 \\
13 & 2 & 0.63 & 10 \\
9 & 3 & 0.63 & 10 \\
6 & 4 & 0.63 & 10 \\
2 & 5 & 0.63 & 10 \\
Midwestern fields & & & 150 \\
76 & 0 & 1.04 & 150 \\
58 & 5 & 1.04 & 150 \\
40 & 10 & 1.04 & 150 \\
22 & 15 & 1.04 & 150 \\
4 & 20 & 1.04 & 150 \\
-14 & 25 & 1.04 & \\
\hline
\end{tabular}

does not extract nutrients in a homogeneous manner from the field; instead, nutrients are extracted from more or less cone-shaped root volumes that overlap in differing ways, depending on plant densities and planting patterns.

In the case of the Southwestern crop, the root cone beneath a hill consists of four or five root systems occupying the same volume (Fig. 10a). Note that for the purpose of illustration only, near-surface roots are assumed to extend only $1 \mathrm{~m}$ outward from the stalk. In addition, because it is difficult to illustrate the overlapping root volumes, the overlapping root cones are shown as vertically arrayed triangles. The combined root system supplies nutrients to four or five aboveground plants; thus, the nutrient demand on the soil volume occupied by the roots is four to five times greater than that required by a single plant.

In the Midwestern field, the closely spaced stalks entail the overlap of 16 root volumes along the row (Fig. 10b). In addition, the 16 overlapping root volumes in one row overlap 16 overlapping root volumes in an adjacent row (Fig. 10c). For all practical purposes, maize growing in the Midwestern field is associated with 32 overlapping root volumes; thus, the nutrient demand on the soil volume occupied by the roots is 32 times greater than that required by a single plant. This implies that the nutrient demand in a Southwestern root zone is $14 \%$ of the nutrient demand in a Midwestern root zone, all other factors being equal.

It should be noted that hybrid and Southwestern maize varieties do not have the same ability to extract nutrients from the soil; for example, Sandor et al. (2007) have shown that Zuni Blue maize is better adapted to mobilizing these nutrients at elevated soil $\mathrm{pH}$ values.

The $\mathrm{NO}_{3}-\mathrm{N}$ Indicator

Calculations using data contained in Tables 2 and 4 indicate that the average aboveground maize plant contains $3.3 \mathrm{~g} \mathrm{~N}$. In a 1-ac field, containing 440 hills with an average of 4.5 plants/hill, the aboveground plants contain a total of $6.6 \mathrm{~kg}$ of N. If Southwestern Native American maize contained the same proportions of grain, 

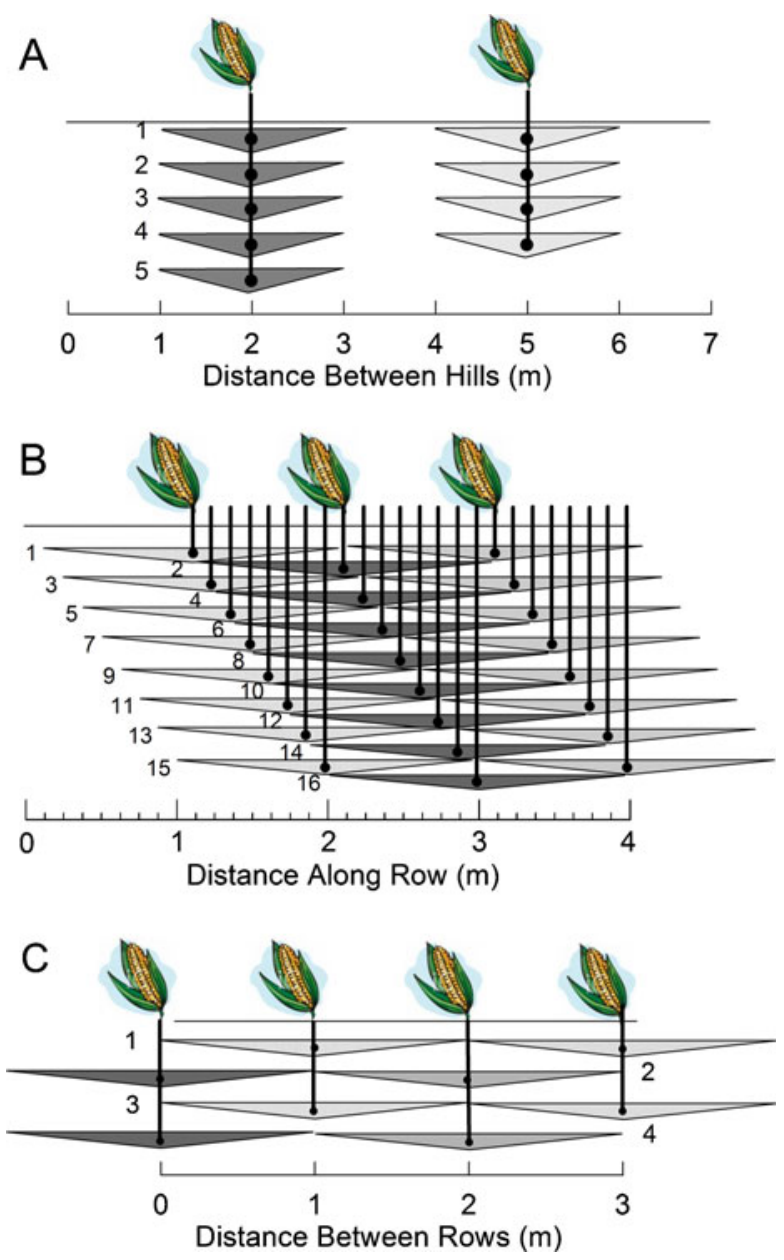

Fig. 10 Root cone densities associated with different planting patterns. a Archetypal planting pattern used by early historic Southwestern Native Americans (4.5 plants per hill and 2,000 plants per acre); view is down row. b Archetypal modern Midwestern planting pattern (32,000 plants per acres and 1-m distance between rows); view is along row. c Midwestern planting pattern; view is down row. Vertically arranged and numbered triangles indicate root cones that actually are at the same depth below the field surface

stover, and cob as modern hybrid maize, $5.8 \mathrm{~kg}$ of $\mathrm{N}$ would be consumed by aboveground plants producing $10 \mathrm{bu}(254 \mathrm{~kg})$ of grain (Tables 2 and 4). However, given prehistoric grain loss due to plant disease, insect, and animal predation, $6.6 \mathrm{~kg} \mathrm{~N}$ value will be assumed to have been consumed in the production of $10 \mathrm{bu} / \mathrm{ac}$ of prehistoric Southwestern maize.

No consistent recommendation exists for rapid estimation of the $\mathrm{N}$ mineralization capacity of a soil. In general, chemical extraction methods are wanting because they do not replicate the action of soil microorganisms responsible for $\mathrm{N}$ mineralization, and while biological incubations under standardized conditions are reasonably reliable, they take too long and are too labor-intensive for practical use (Bremmer 1965). 
Table 4 Nitrogen and Phosphorus in Corn Dry Matter

\begin{tabular}{llllcr}
\hline & Grain & Stover & Cob & Stover and cob & Source \\
\hline$\% \mathrm{~N}$ & 1.44 & 0.81 & 0.33 & 0.74 & 1 \\
& 1.59 & & & 0.71 & 3 \\
& 1.54 & & 0.67 & 4 \\
& 1.36 & & 0.65 & \\
Average & 1.48 & & & 0.69 & 1 \\
\%P & 0.301 & 0.061 & 0.048 & 0.055 & 4 \\
& 0.297 & & & 0.129 & \\
& 0.33 & & & 0.084 & \\
& & & & 0.089 & \\
\hline
\end{tabular}

1 Sawyer and Mallarino (2007); 2 Sawyer et al. (2008); 3 Hay et al. (1953); 4 Barber and Olson (1968)

Wang et al. (2001) evaluated several chemical indices of $\mathrm{N}$ mineralization capacity and concluded that "none of the chemically hydrolyzed $\mathrm{N}$ fractions consistently showed closer relationships with $\mathrm{N}$ mineralization (measured by incubation experiments) than total organic $\mathrm{N}$, suggesting that these chemical methods are ineffective in extracting a biologically labile fraction of soil organic C." Recognizing that estimates of $\mathrm{N}$ availability based on soil $\mathrm{NO}_{3}-\mathrm{N}$ concentrations are of limited value because of the transient nature of $\mathrm{NO}_{3}$, preplant soil profile $\mathrm{NO}_{3}$ tests can still provide a useful means of assessing the probable contribution of soil $\mathrm{NO}_{3}$ to crop $\mathrm{N}$ needs (Dahnke and Johnson 1990; Hergert 1987); postplant measurements of the concentration of $\mathrm{NO}_{3}-\mathrm{N}$ in the soil when plants are $15-30 \mathrm{~cm}$ tall are particularly useful.

With respect to the Southwest, Doerge (1985) has suggested that when the preplant $\mathrm{NO}_{3}-\mathrm{N}$ value is $<5 \mu \mathrm{g} / \mathrm{g}$ in the upper $30 \mathrm{~cm}$ of the soil in Arizona, fertilizer should be applied. Unfortunately, Doerge (1985) does not specify to what plant density this values applies. Mortvedt et al. (2007) has recommended that the rate of $\mathrm{N}$ fertilization be reduced $3.6 \mathrm{~kg}$ for each microgram per gram $\mathrm{NO}_{3}-\mathrm{N}$ in the upper $60 \mathrm{~cm}$ of soil.

Because much of the fertilizer $\mathrm{N}$ applied in the early spring in humid areas is often lost from the plow zone (surface $30 \mathrm{~cm}$ ) before the plants are $15 \mathrm{~cm}$ tall, some soil scientists have suggested testing the soil for $\mathrm{NO}_{3}-\mathrm{N}$ when the plants reach $15 \mathrm{~cm}$ (Blackmer et al. 1989). However this analysis is less useful when the spring is typically cool and dry and where the soil is highly leachable and unstructured (Bundy and Meisinger 1994), for example, the semiarid American Southwest. Studies across a wide range of environmental conditions indicate that when plants are $15-30 \mathrm{~cm}$ tall, $\mathrm{NO}_{3}-\mathrm{N}$ concentrations in the range $20-25 \mu \mathrm{g} / \mathrm{g}$ result in optimal maize yields (Bundy and Meisinger 1994; Fox et al. 1989; Magdoff et al. 1984; Schroeder et al. 2000).

Unfortunately, we do not know how the $\mathrm{NO}_{3}-\mathrm{N}$ is distributed within the top meter of soil in the studies referenced above; however, if it is uniformly distributed with depth, the optimal $20-25 \mu \mathrm{g} / \mathrm{g} \mathrm{NO}_{3}-\mathrm{N}$ range implies that a 1-m-thick 1-ac field contains between 121 and $152 \mathrm{~kg}$ of $\mathrm{NO}_{3}-\mathrm{N}$ (assuming a soil density of $1.5 \mathrm{~g} / \mathrm{cm}^{3}$ ). This amount of $\mathrm{N}$ would certainly counter much of the $106 \mathrm{~kg}$ of $\mathrm{N}$ extracted from 
the soil by aboveground grain and stover grown in the Midwest at a density of 32,000 plants/ac. However, a Midwestern root cone contains only $45-57 \mathrm{~g}$ of the $106 \mathrm{~g}$ of $\mathrm{NO}_{3}-\mathrm{N}$ necessary to support 32 maize plants. Thus, only about half of the $\mathrm{N}$ consumed by Midwestern maize is available in the overall root zone volume when the $\mathrm{NO}_{3}-\mathrm{N}$ is between 20 and $25 \mu \mathrm{g} / \mathrm{g}$.

Our derived nutrient scaling factor indicates that the soils of Southwestern fields planted in a Native American style should optimally contain 3-4 $\mu \mathrm{g} / \mathrm{g} \mathrm{NO} \mathrm{NO}_{3}-\mathrm{N}$. A Southwestern root cone with this range of $\mathrm{NO}_{3}-\mathrm{N}$ contains only $6.8-9.1 \mathrm{~g}$ of the $14.8 \mathrm{~g}$ of $\mathrm{NO}_{3}-\mathrm{N}$ necessary to support 4.5 maize plants. However, if the cone contains a labile organic $\mathrm{N}$ concentration of $0.030 \%$ (the mean study area value - see "Nitrogen and Carbon in Study Area Soils"), then a N mineralization rate of $1.5 \% / \mathrm{yr}$ results in the production of $10 \mathrm{~g}$ of $\mathrm{NO}_{3}-\mathrm{N}$, which is sufficient to supplement the growth of 4.5 maize plants occupying a single root volume.

The P Indicator

Maize dry matter is composed of $0.19 \% \mathrm{P}$, and an average hybrid maize plant contains $0.61 \mathrm{~g} \mathrm{P}$ (Tables 2 and 4; Shinners and Binversie 2007). Therefore, the aboveground parts of 32,000 maize plants in a Midwestern field extract $19.52 \mathrm{~kg} P$ per acre and the aboveground parts of 2000 Southwestern Native American plants extract $1.22 \mathrm{~kg} \mathrm{P}$ per acre.

Unlike $\mathrm{NO}_{3}-\mathrm{N}, \mathrm{PO}_{4}-\mathrm{P}$ is not released by decay of an organic precursor. Instead, its solution concentration is mostly controlled by the solubilities of calcium phosphate mineral phases and by $\mathrm{P}$ release from sorption sites on aluminum and iron oxides and oxyhydroxides (see, e.g., Boehm 1971; Mattson and Pugh 1934).

There are three principal methods used to determine available $\mathrm{P}\left(P_{\mathrm{AV}}\right)$ in soils - the Mehlich-3, Bray-1, and Olsen-P procedures. Details of each of these P extraction techniques can be found in Pierzynski (2000). The Olsen-P method is primarily used in the western USA and is best suited for calcareous soils. Sawyer et al. (2008) recommend an optimum Olsen-P range of 11-14 $\mu \mathrm{g} P_{\mathrm{AV}}$ per gram soil for Midwestern maize yields of $150 \mathrm{bu} / \mathrm{ac}$ (equivalent to $\sim 32,000 \mathrm{plants} / \mathrm{ac}$ ). A $1.51-\mathrm{m}^{3}$ root cone with a soil density of $1.5 \mathrm{~g} / \mathrm{cm}^{3}$ would contain $25-32 \mathrm{~g} P_{\mathrm{AV}}$, and the roots of 32 overlapping maize plants would extract $19.5 \mathrm{~g}$ P. Therefore, the amount of $P_{\mathrm{AV}}$ in the optimum range exceeds the amount of $\mathrm{P}$ extracted by maize (note that this calculation ignores the $\mathrm{P}$ contained in the organic root ball). Given that the Midwestern field nutrient demand is 7.1 times that of a Southwestern Native American field, 1.5-2.0 $\mu \mathrm{g} P_{\mathrm{AV}}$ per gram soil of Olsen-P should be sufficient for a Southwestern maize crop.

\section{An Evaluation of Maize Agriculture Within the Overall Study Area}

Climate of the Study Area

\section{Indices of Climate Change}

As previously summarized by Benson et al. (2007), during the past 1,000 years, drought in the Four Corners region can often be associated with two climate 
indices - the Pacific Decadal Oscillation (PDO) and the Atlantic Multidecadal Oscillation (AMO). The PDO has a spatial pattern similar to the El Nino Southern Oscillation (ENSO) (Mantua et al. 1997); that is, during positive phases of the PDO, the Southwest tends to be wetter than average and during negative phases of the PDO, the Southwest tends to be drier than average. However, the PDO has a very different time constant, having a pseudo-cyclicity ranging from 50 to 70 years (MacDonald and Case 2005), whereas typical ENSO events occur every 4 to 7 years and persist for only 6-18 months. A positive PDO phase is associated with warmer-than-normal temperatures in the eastern equatorial Pacific Ocean and cooler-than-normal temperatures in the northwest Pacific Ocean.

The AMO is an index of detrended sea surface temperature (SST) anomalies that are averaged over the North Atlantic Ocean from 0 to $70^{\circ} \mathrm{N}$ (Kerr 2000). The detrended AMO index has been associated with multiyear precipitation anomalies over North America, and it has been shown to influence summer precipitation over the USA (Enfield et al. 2001). During the instrumental period (1856-2005), the AMO has exhibited a 65 - to 80 -year pseudo cycle.

Atmospheric modeling has demonstrated that the drought of the 1930s, which affected approximately two thirds of the contiguous USA, was associated with warmer-than-normal North Atlantic SSTs (positive AMO) and colder-than-normal equatorial Pacific SSTs (negative PDO; Schubert et al. 2004). McCabe et al. (2004), using drought frequency climate data for the period 1900-1999, have demonstrated that the southern part of the western USA tends to experience drought when the AMO is positive and the PDO is negative. Brown and Comrie (2002) and Ni et al. (2002) have shown that winter precipitation in New Mexico is positively correlated with the PDO, and Fye et al. (2003) have shown that times of positive AMO and negative PDO produce western droughts that are spatially similar to the $1950 \mathrm{~s}$ drought. The 1950s drought actually occurred between 1946 and 1956 and was especially severe in the Southwest. During the 1950s drought, both winter and summer precipitation regimes declined dramatically. Thus, in the historical period, a negative PDO and a positive AMO are nominally associated with drought in the study area.

To determine the relation of water-year (October 1 of the prior year through September 30 of the water-year) precipitation in the study area to negative and positive PDO intervals, Benson et al. (2007) analyzed historical climate records from 15 sites (weather stations) in New Mexico and Colorado. The data indicate that a negative PDO interval is characterized by reduced water-year precipitation.

In order to look back farther in time, before the instrumental period, we must turn to proxies for the PDO, AMO, and drought. Tree ring (D'arrigo et al. 2001; Gray et al. 2004) and coral chemistry (Linsley et al. 2000) records have been used to reconstruct fluctuations in the PDO and AMO for about the past 300 years. Benson et al. (2007) compared these climate indices with tree ring-based reconstructions of summer PDSI for northwestern New Mexico site \#119 (Cook et al. 2004) and with reconstructions of annual precipitation for Chaco Canyon and demonstrated that prehistoric drought in the San Juan Basin was generally associated with a positive AMO and a negative PDO.

Recently, a much longer PDO record (A.D. 993 to 1996) was constructed by MacDonald and Case (2005). Benson et al. (2007) compared this record with tree 
ring-based of precipitation records for Chaco and the Chuska Mountains as well as a PDSI record for northwestern New Mexico and showed that negative oscillations in the PDO were associated with the middle-twelfth and late-thirteenth century megadroughts. This suggests that during megadroughts, winter frontal systems associated with the positioning of the polar jet stream remained north of the San Juan Basin.

\section{Precipitation}

Contour plots of precipitation data from 140 weather stations in the study area (Electronic Supplementary Materials (ESM) Table $1^{2}$ ) indicate that northwestern New Mexico and northeastern Arizona are deficient in annual precipitation with respect to the dryland production of maize (Fig. 11a). The same holds true for summer (June, July, August, and September) precipitation (Fig. 11b). Precipitation in southwestern Colorado is winter (October through March) dominated (Fig. 11c), whereas the southeastern and northeastern parts of the study area receive as much summer as winter precipitation (Fig. 11d).

Summer precipitation is delivered to the study area via the North American Monsoon (NAM). The NAM typically occurs from July 1 through September 30, with the bulk of moisture advected from the eastern tropical Pacific Ocean and the Gulf of California (Adams and Comrie 1997). Southern Arizona, eastern Arizona, New Mexico, and south-central Colorado receive precipitation related to the NAM; however, rainfall amounts are much more variable than in northwestern Mexico which receives up to $70 \%$ of its annual rainfall in July, August, and September. The spatial and temporal variability of the NAM is due to the fact that it generates highly localized convective events (thunderstorms; McDonald 1956).

Benson et al. (2007) have shown that long-term tree ring-based reconstructions of precipitation in and around the San Juan Basin are nearly identical to tree ring-based reconstructions of the PDSI. Thus, we consider that tree ring-based PDSI reconstructions for sites within the southern Colorado Plateau primarily reflect variability in winter moisture. This suggests that prehistoric megadroughts, including the middle-twelfth and late-thirteenth century megadroughts that impacted southwestern Native American cultures, were primarily characterized by dry winters.

\section{Growing Degree Days}

The calculation of GDD used in this study for maize differs from that tabulated by the Western Regional Climate Center (2009). In this study, GDD was calculated for the four summer months (June through September). Degree days were only accumulated for the mean freeze-free period (90\% probability) and were centered on August 1; for example, if the freeze-free period was 100 days, the calculation would begin on June 12 and end on September 15.

Contour plots of GDD (ESM Table 1 and Fig. 12) determined at 125 weather stations in the study area indicate that much of the San Juan-La Plata mountain region in southwestern Colorado is too cold $(<1,000$ GDD) for the production of

\footnotetext{
${ }^{2}$ A map showing the locations of weather stations in the study area is shown in ESM Fig. 1.
} 

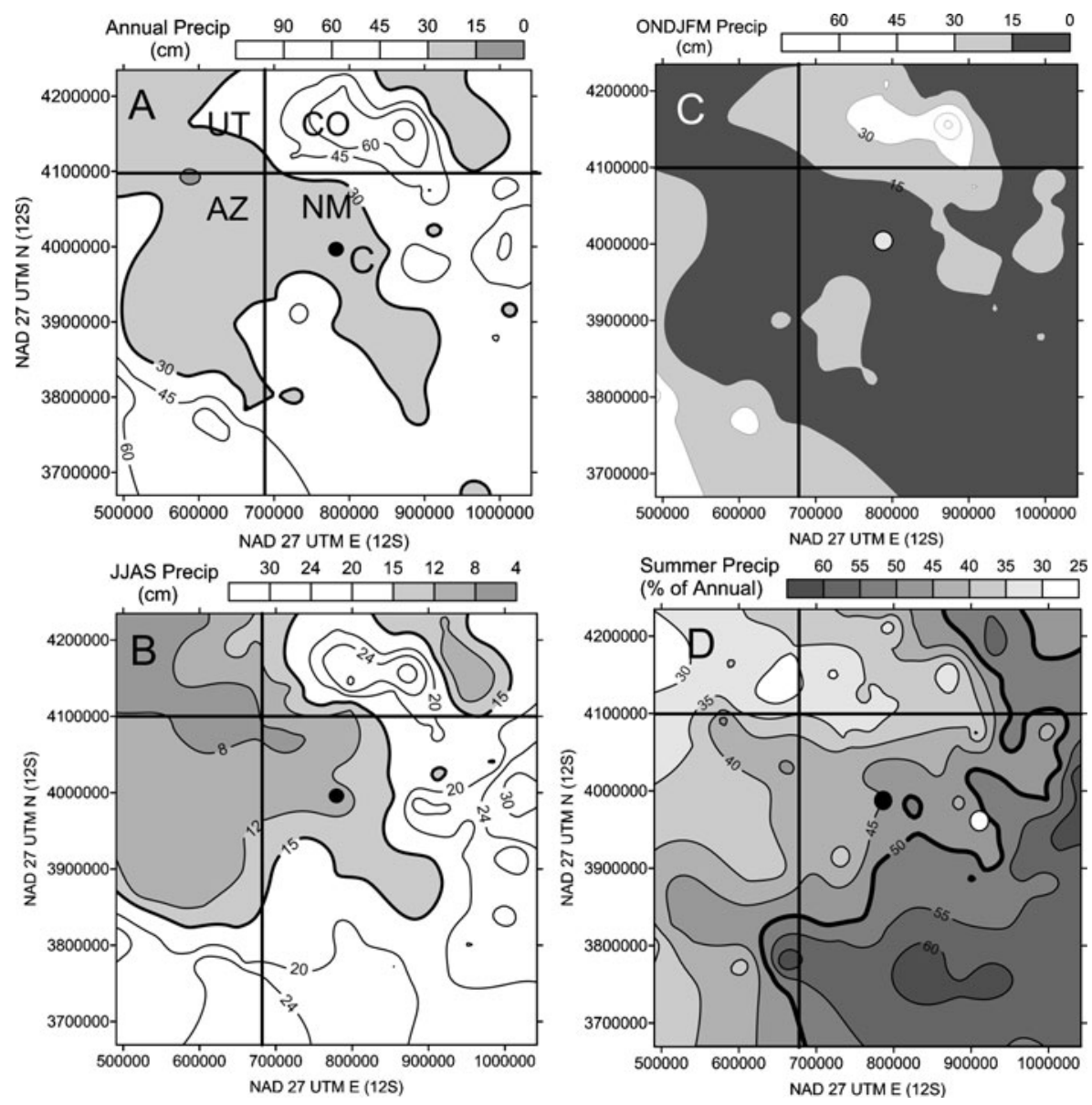

Fig. 11 a Contour plot of mean annual precipitation (periods of record) within the study area. $C$ Chaco Canyon. b Summer (June, July, August, and September) precipitation within the study area. c Winter (October, November, December, January, February, and March) precipitation within the study area. d. Summer precipitation as percent of annual precipitation

maize. This also holds true for the Sangre de Cristo mountain area as well as the area south of Chaco that lies just east of the New Mexico-Arizona border.

\section{The Chemistries of Study Area Soils}

In the following, four parameters used by modern agronomists and farmers to assess field fertility and nutrient availability are discussed, including salinity/electrical conductivity (EC), $\mathrm{pH}$, available phosphorus $\left(P_{\mathrm{AV}}\right)$, and $\mathrm{NO}_{3}-\mathrm{N}$. The distribution of organic $\mathrm{N}$ (proxied by organic $\mathrm{C}$ ), $\mathrm{EC}$, and $\mathrm{pH}$ within the study area are illustrated using soil pedon data collected from between 235 and 290 sites and tabulated by the Natural Resources Conservation Service (U.S. Department of Agriculture 2009).

A pedon is essentially a soil profile exposed within the wall or walls of a pit. Field observations of the morphology of the soil are combined with physical and chemical 


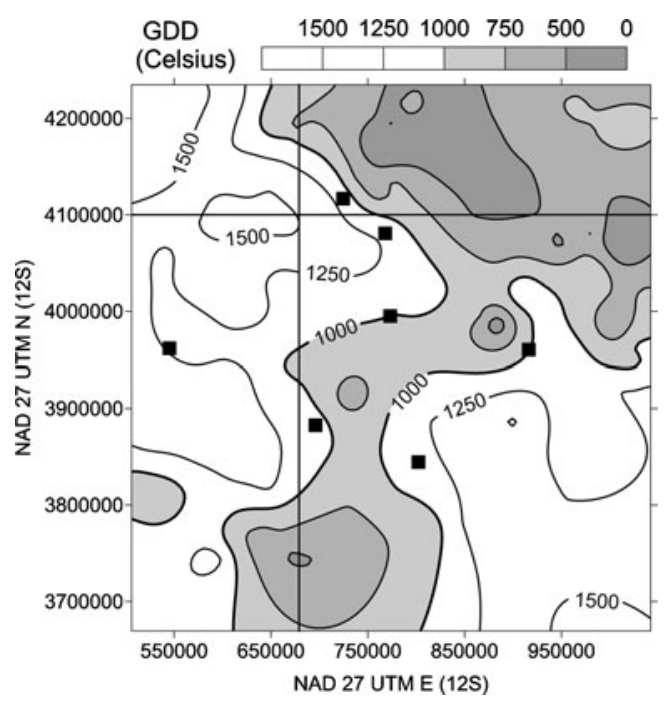

Fig. 12 Contour plot of growing degree days $(G D D)$ within the study area. $C$ Chaco Canyon

measurements of individual soil units within a pedon in order to describe and classify it. Each unit consists of a volume of soil having a relatively invariant set of physical properties such as texture and color (Wilson and Artiola 2004). Measurements of unit thickness, density, grain size, EC, moisture content, and $\mathrm{pH}$ are commonly made. Measurements of total or organic $\mathrm{C}$ and $\mathrm{N}$ are less common, and measurements of plant nutrients such as $P_{\mathrm{AV}}$ and $\mathrm{NO}_{3}-\mathrm{N}$ are generally unavailable for soils in the study area.

\section{Nitrogen and Carbon in Study Area Soils}

The ratio of organic carbon to organic $\mathrm{N}(\mathrm{C} / \mathrm{N})$ in 670 soil samples from the study area is $10.6 \pm 4.5$ (Fig. 13b and ESM Table $2^{3}$; U.S. Department of Agriculture 2009). The average organic $\mathrm{C}$ content in the top $1 \mathrm{~m}$ of soil in 192 pedons from the study area is $0.63 \pm 0.58 \%$ (Fig. 13a and ESM Table 2); therefore, the average organic $\mathrm{N}$ content of the soil is approximately $0.060 \%$. The average density of the 1,193 soil samples in the study area is $1.55 \pm 0.40 \mathrm{~g} / \mathrm{cm}^{3}$ (U.S. Department of Agriculture 2009); therefore, a 1-m-deep 1-ac field contains, on average, $37 \mathrm{~kg}$ of organic N.

The first, second, and third quartiles of the organic $\mathrm{C}$ values of the top $0.5 \mathrm{~m}$ of soil in the study area are, respectively, $0.37 \%, 0.62 \%$, and $1.18 \%$; quartile organic $\mathrm{N}$ values associated with the organic $\mathrm{C}$ values are, respectively, $0.035 \%, 0.059 \%$, and $0.111 \%$. The organic $\mathrm{C}$ concentration in the top $50 \mathrm{~cm}$ of 235 soil pedons (ESM Table 2) is contoured in Fig. 14. This plot indicates a tongue of low organic C concentration running southeastward from the Four Corners. The San Juan Basin comprises much of the area that has organic $\mathrm{C}$ concentrations that fall below $0.4 \%$

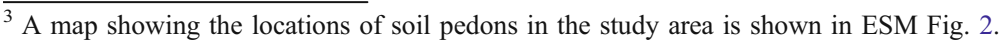



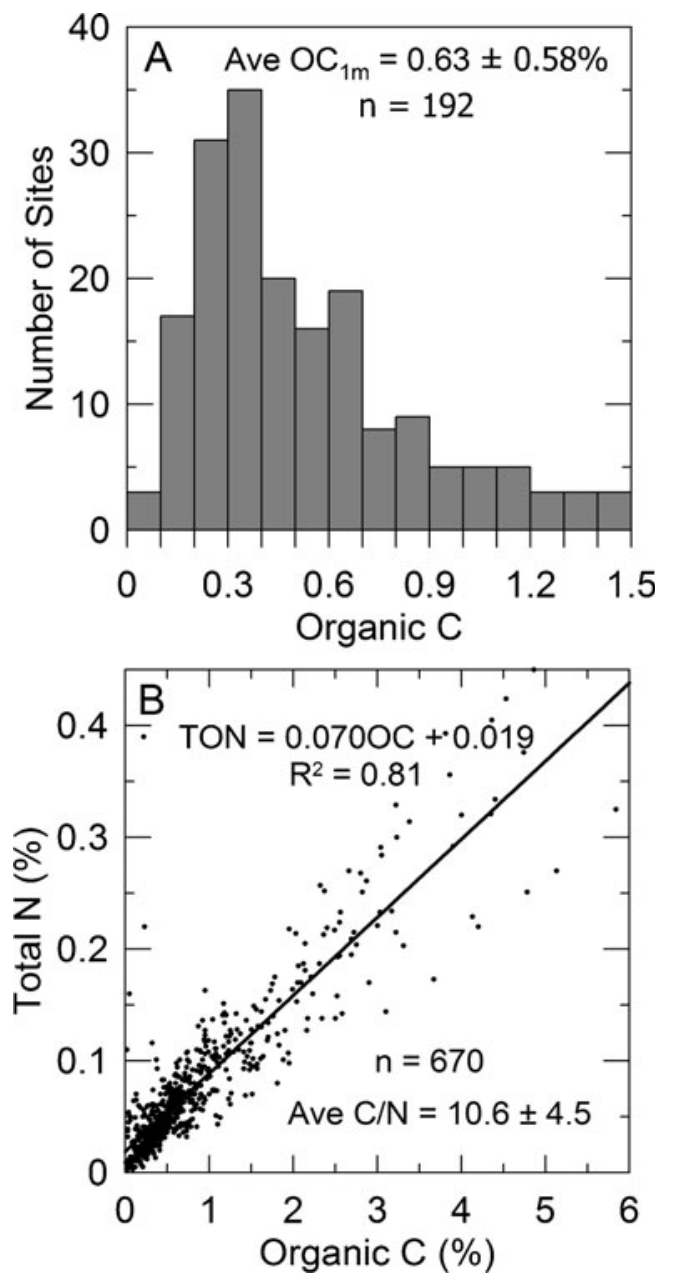

Fig. 13 a Histogram indicating the distribution of organic carbon $(O C)$ in the top $1 \mathrm{~m}$ of soil from 192 soil pedons within the study area. b Correlation of total N (TON composed of mostly organic N) with organic carbon within 670 samples from soil pedons within the study area

and the northeastern part of Arizona also is organic C-deficient. This suggests that organic $\mathrm{N}$ also may be deficient with respect to maize productivity in both areas.

Calculations using the data in Tables 2 and 4 and data from Shinners and Binversie (2007) indicate that the average hybrid maize plant contains $3.3 \mathrm{~g} \mathrm{~N}$ and $0.61 \mathrm{~g}$ P. Thus, the raising of 2,000 plants/ac in a Southwestern Native American field consumes $6.6 \mathrm{~kg} \mathrm{~N}$ and $1.22 \mathrm{~kg}$ P. However, the application of the average value of $\mathrm{N}$ consumption to a 1-m-deep 1-ac field does not provide the most accurate way of calculating how many years the average soil in our study area would remain viable for an annual crop without the need for additional fertilizer. Instead, we choose to calculate field life using the fact that the root volume that accesses soil $\mathrm{NO}_{3}-\mathrm{N}$ is in the form of an inverted cone having a $1.2-\mathrm{m}$ radius, a $1.44-\mathrm{m}^{2}$ basal area, a $1.0-\mathrm{m}$ height, and a $1.51-\mathrm{m}^{3}$ volume. This does not imply that the root ball 


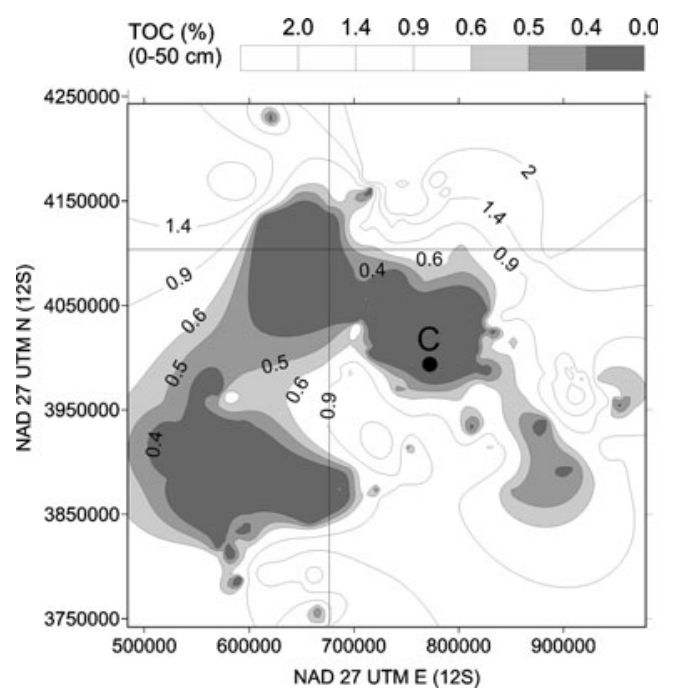

Fig. 14 Contour plot of percent total organic carbon (TOC) in the top $50 \mathrm{~cm}$ of soil within the study area. The average TOC value for the top $1 \mathrm{~m}$ of soils in the study area is $0.63 \%$ and the median value is $0.47 \%$. Data for the top $50 \mathrm{~cm}$ of soils have been contoured because there is substantially more data for $50 \mathrm{~cm}$ than for $100 \mathrm{~cm}$. C Chaco Canyon

occupies the same field volume year after year; in fact, the Zuni annually shifted their hills $10-13 \mathrm{~cm}$ downwind from the location of the previous year's stalks (Cushing 1920). If we assume a 12.5-cm shift and a hill spacing of $3 \mathrm{~m}$, it would take 24 years for the cone-shaped root mass to move from one row to an adjacent hill row.

Previous discussions have demonstrated that much of the organic $\mathrm{C}$ and organic $\mathrm{N}$ in the top $1 \mathrm{~m}$ of soil is recalcitrant, non-hydrolyzable, and, therefore, essentially inert (see, e.g., Figs. 6 and 7). Data on the non-hydrolyzable content of Southwestern soils is lacking; however, data for other regions of North America (Table 5) suggest that approximately $50 \%$ of the upper $30-50 \mathrm{~cm}$ of North America soils is mineralization recalcitrant. Given the low amounts of mineralizable $\mathrm{C}$ and $\mathrm{N}$ below $50 \mathrm{~cm}$ (Fig. 7), the following calculations of field life assume that $50 \%$ of the total organic $\mathrm{C}$ and $\mathrm{N}$ in the upper $50 \mathrm{~cm}$ of Southwestern fields is unavailable for $\mathrm{N}$ mineralization. Extraction of $\mathrm{N}$ from only the upper $50 \mathrm{~cm}$ of soil is also consistent with data on elevated salinities of deeper soils in the study area. The highly saline soils below $50 \mathrm{~cm}$ are often detrimental to maize growth and root development (see "Salinities of Study Area Soils").

For our demonstration calculation of prehistoric Southwestern agricultural field life (Eq. 0.9), we set $N_{0}$ to $614 \mathrm{~g}$ organic $\mathrm{N}$ (the amount of organic $\mathrm{N}$ in the top $0.5 \mathrm{~m}$ of a root ball having a soil volume of $1.32 \mathrm{~m}^{3}$, a soil density of $1.55 \mathrm{~g} / \mathrm{cm}^{3}$, and a labile organic $\mathrm{N}$ concentration of $0.030 \%$ - half the median value in the upper $50 \mathrm{~cm}$ of soil). In addition, it is assumed that $m$ (the mean rate of mineralization) ranges between $1 \%$ and $3 \%$ year, and $N_{\text {EXT }}$ (the amount of $\mathrm{NO}_{3}-\mathrm{N}$ consumed annually, see Eq. 1.0$)$ is equal to $14.85 \mathrm{~g} /$ year $(4.5$ plants $\times 3.3 \mathrm{~g} / \mathrm{plant}) . F_{\mathrm{STO}}$ (the fraction of excess $\mathrm{NO}_{3}-\mathrm{N}$ stored in the soil annually, see Eq. 1.0) is set to either 0.0 or 0.5 . 
Table 5 Soil Total Organic Carbon (TOC) and Non-hydrolyzable Carbon (NHC)

\begin{tabular}{|c|c|c|c|}
\hline Site information & Soil depth $(\mathrm{cm})$ & TOC $(\mathrm{g} / \mathrm{kg})$ & NHC $(\%)$ \\
\hline Soil: loam & $0-10$ & 14.7 & 56 \\
\hline Setting: native prairie & $10-20$ & 10.1 & 45 \\
\hline Site: Akron, Colorado & $20-30$ & 9.2 & 44 \\
\hline Reference: Follet et al. (1997) & $30-60$ & 5.4 & 29 \\
\hline Soil: silt loam & $0-23$ & 13.0 & 79 \\
\hline Setting: orchard grass meadow & $23-30$ & 4.4 & 75 \\
\hline Site: Coshocton, Ohio & $30-46$ & 2.4 & 71 \\
\hline Reference: Lorenz et al. (2006) & $46-69$ & 1.9 & 75 \\
\hline Soil: silt loam & $0-28$ & 9.7 & 73 \\
\hline Setting: continuous no-till corn & $28-36$ & 3.5 & 78 \\
\hline Site: Coshocton, Ohio & $36-51$ & 2.0 & 79 \\
\hline Reference: Lorenz et al. (2006) & $51-74$ & 1.5 & 82 \\
\hline Soil: various & $(n=30)$ surface $^{\mathrm{a}}$ & & 55 \\
\hline Setting: transect & $(n=18)$ subsurface $^{\mathrm{b}}$ & & 44 \\
\hline \multicolumn{4}{|l|}{ Site: Michigan, Arizona, Great Plains } \\
\hline \multicolumn{4}{|l|}{ Reference: Leavitt et al. (1996) } \\
\hline Soil: various & $0-20$ & 17.9 & 49 \\
\hline Setting: grassland in continuous corn & $25-50$ & 8.7 & 45 \\
\hline Site: Lamberton, Minnesota & $50-100$ & 4.3 & 48 \\
\hline \multicolumn{4}{|l|}{ Reference: Paul et al. (2001) } \\
\hline Soil: various & $0-20$ & 17.3 & 50 \\
\hline Setting: grassland in continuous corn & $25-50$ & 8.5 & 35 \\
\hline Site: Arlington, Wisconsin & $50-100$ & 3.0 & 30 \\
\hline \multicolumn{4}{|l|}{ Reference: Paul et al. (2001) } \\
\hline Soil: various & $(n=115) 0-10$ & & 44 \\
\hline Setting: grassland & $(n=30) \quad 10-20$ & & 46 \\
\hline Site: North America & $(n=7) 20-30$ & & 34 \\
\hline \multirow[t]{2}{*}{ Reference: Paul et al. $(2006)^{\mathrm{c}}$} & $(n=4) 40-50$ & & 71 \\
\hline & $(n=6)>50$ & & 71 \\
\hline
\end{tabular}

\footnotetext{
${ }^{\text {a }}$ Surface samples were collected from $0-10,0-15$, or $0-30 \mathrm{~cm}$

${ }^{\mathrm{b}}$ Subsurface samples were collected from 10-20 up to $90-120 \mathrm{~cm}$

${ }^{\mathrm{c}}$ Paul et al. (2006) NHC values refer to mean values
}

Plant-available $\mathrm{N}$ is mostly in the form of $\mathrm{NO}_{3}{ }^{-}$which carries a negative charge. Given that most mineral surfaces also carry a negative charge, conversion of organic $\mathrm{N}$ to $\mathrm{NO}_{3}-\mathrm{N}$ is accompanied by substantial losses of $\mathrm{NO}_{3}{ }^{-}$, which percolates through the soil zone during the first year of application; that is, studies have shown that often more than half of the $\mathrm{N}$ applied is lost from Midwestern fields $\left(F_{\mathrm{STO}}=0.50\right)$ by processes other than crop harvest (see, e.g., Allison 1955; Cerrato and Blackmer 1990; Hesterman et al. 1987; Timmons and Cruse 1990). The lost $\mathrm{NO}_{3}{ }^{-}$probably represent nearly all $\mathrm{NO}_{3}-\mathrm{N}$ not consumed by the maize. 
The low plant densities favored by Southwestern Native Americans also favor loss of $\mathrm{NO}_{3}-\mathrm{N}$. The root volume associated with a hill of Southwestern Native American maize is $1.51 \mathrm{~m}^{3}$; thus, the total root volume associated with 440 hills in a 1 -ac field is $664 \mathrm{~m}^{3}$ or only $16.4 \%$ of the total field volume. Therefore, $83.6 \%$ of the volume of a 1-ac field lacks maize roots in any particular year, and most of the $\mathrm{NO}_{3}-$ $\mathrm{N}$ produced annually within the unoccupied volume is free to pass through the field without being accessed by maize. It follows that a $F_{\text {STO }}$ value of 0.0 most closely approximates the fraction of $\mathrm{NO}_{3}-\mathrm{N}$ stored in Southwestern Native American field. However, this does not account for the organic $\mathrm{N}$ carried over in a previous crop's root system.

The rate of $\mathrm{N}$ mineralization affects field life; for example, field life is $>0$ years only when the rate of mineralization $(m)$ is equal to $3.0 \% / y e a r$ (Fig. 15a, b). The carryover of $50 \%$ of the excess $\mathrm{NO}_{3}-\mathrm{N}$ does not substantially increase field life. Note that field life will remain the same for plant densities $<3,150$ plants/ac (700 hills/ac), i.e., until the 2.4-m diameter root cones begin to overlap. This implies that a plant density of 700 hills/ac could produce 17.5 bu of grain without additional loss of productivity.

In Fig. 15c, the change in $\mathrm{NO}_{3}-\mathrm{N}$ over time is shown for fields containing study area first, second, and third quartile values of organic $\mathrm{N}$ (respectively, $0.035 \%$, $0.059 \%$, and $0.111 \% \mathrm{~N}$ ), equivalent to 364,614 , and $1,155 \mathrm{~g}$ of labile organic $\mathrm{N}$ in the 0.5 -m-deep soil frustum. The rate of mineralization has been set to a very high value, i.e., $2.0 \% /$ year. If the value was set to $1.0 \%$ /year, none of the fields is capable of producing a 10-bu/ac crop of maize. As it stands, only the fields with $\mathrm{N}$ exceeding the third quartile value are able to produce a crop for an extended period of time (21 year). It is obvious that nearly three quarters of the study area does not contain sufficient organic $\mathrm{N}$ to produce a 10 -bu/ac crop of maize during even the first year of cultivation. It should be noted, however, that these calculations do not account for the possibility of organic $\mathrm{N}$ being transported to the agricultural fields. Neither do they account for the possibility of planting less than an average of 4.5 plants per hill. As will be discussed in the "Nitrogen Sources," Zuni agricultural practices entailed the natural transport of organic $\mathrm{N}$ to their field systems which greatly prolonged field life.

The preceding calculations of the production of available $\mathrm{NO}_{3}-\mathrm{N}$ over time may be somewhat simplistic and overgenerous in terms of productivity in that they assume that the $\mathrm{NO}_{3}-\mathrm{N}$ reservoir is well mixed and that $\mathrm{NO}_{3}-\mathrm{N}$ produced in the lower part of the soil zone is not lost before roots reach that depth. In addition, the semiarid West generally favors a low mineralization rate; that is, the mineralization rate may never reach 3.0\%/year even in wet years.

Obviously, $\mathrm{NO}_{3}-\mathrm{N}$ is not free to move laterally within the 1-m-deep soil zone; therefore, the assumption of a well-mixed reservoir within the root cone implies that the maize's roots are able to systematically access the entire $1.51-\mathrm{m}^{3}$ volume. Root length density, mass, and volume decrease exponentially with depth (Dwyer et al. 1996; Fehrenbacher and Rust 1956; Qin et al. 2006) and the root volume expands and deepens with time; for example, root length density contours descend relatively slowly over a 16-week growing period. The soil volume containing $>10,000 \mathrm{~m}$ roots $/ \mathrm{m}^{3}$ soil descends through 5,10, 20,30, 40 and $45 \mathrm{~cm}$ at, respectively, 6, 8, 10, 12, 14, and 16 weeks (Nakamoto 1989). Root biomass plateaus at about 60 days (Amos and 
Fig. 15 Productive lifetimes of study area maize fields with 2,000 plants/ac. a $\mathrm{NO}_{3}-\mathrm{N}$ production when a field initially contains the median study area value of organic $\mathrm{N}(0.059 \%)$ and when excess $\mathrm{NO}_{3}-\mathrm{N}$ is lost after maize consumption of available $\mathrm{NO}_{3}-\mathrm{N}$. Mineralization rates of $1 \%, 2 \%$, and $3 \%$ are used in the calculations. b $\mathrm{NO}_{3}-\mathrm{N}$ production when fields start with median study area value of organic $\mathrm{N}(0.059 \%)$ and half of the excess $\mathrm{NO}_{3}-\mathrm{N}$ is carried over after maize consumption of available $\mathrm{NO}_{3}-\mathrm{N}$. Mineralization rates of $1 \%, 2 \%$, and $3 \%$ are used in the calculations.

c $\mathrm{NO}_{3}-\mathrm{N}$ produced over time when fields start with first $(0.035 \% \mathrm{~N})$, second $(0.059 \% \mathrm{~N})$, and third $(0.111 \% \mathrm{~N})$ quartile $(\mathrm{Q})$ values of study area organic $\mathrm{N}$. Calculations were done in $\mathbf{a}$ and b using organic $\mathrm{N}$ mineralization rates of $1.0 \%, 2.0 \%$, and $3.0 \%$ / year. Calculations were done in c using an organic $\mathrm{N}$ mineralization rate of $2 \%$ /year. Field life (in years) is shown by numbers near/above the shaded rectangles. In all cases, $50 \%$ of the organic $\mathrm{N}$ in the upper $50 \mathrm{~cm}$ of the soil was considered labile. Shaded areas indicate times when root-available $\mathrm{NO}_{3}-\mathrm{N}$ is insufficient to produce $10 \mathrm{bu} / \mathrm{ac}$ of maize
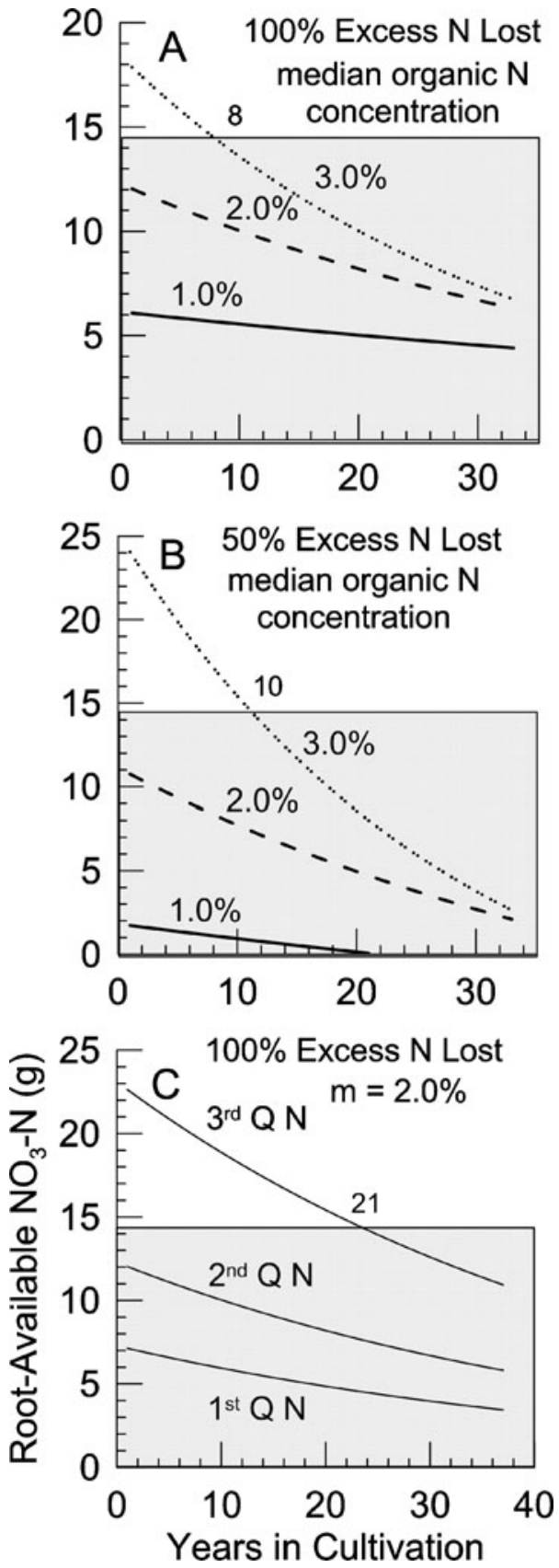

Walters 2006) at approximately the same time as the plateau in LAI (Lindquist et al. 2005). During the early part of the growing season, $\mathrm{NO}_{3}-\mathrm{N}$ produced by the mineralization of organic $\mathrm{N}$ in the lower part of the soil zone may be lost from the field and $\mathrm{NO}_{3}{ }^{-}$. Note that leaching is more efficient in coarse-grained soils typical of those commonly found in the study area (Bundy and Meisinger 1994). 
Questions also remain as to when $\mathrm{NO}_{3}-\mathrm{N}$ is produced and when is it leached. Timing of $\mathrm{NO}_{3}-\mathrm{N}$ availability is critical because in maize, $45-65 \%$ of the grain $\mathrm{N}$ is provided from preexisting $\mathrm{N}$ stored in the stover, and the remaining $35-55 \%$ of grain $\mathrm{N}$ originates from post-silking N uptake (Gallais and Coque 2005; Ta and Weiland 1992).

The principal environmental factors controlling $\mathrm{N}$ mineralization from SOM are water and temperature (e.g., Jarvis et al. 1996; Waksman and Gerretsen 1931). In ecosystems that receive $<60 \mathrm{~cm}$ of mean annual precipitation (most of the study area), primary production is primarily controlled by water availability (Lieth 1975; Noy-Meir 1973; Sala et al. 1988).

The $\mathrm{NO}_{3}$ content of an agricultural soil in a humid temperate climate, such as in the Midwestern USA, is lowest in winter (due to leaching), increases in the late spring and early summer (initiation of $\mathrm{N}$ mineralization), decreases during middle and late summer (crop uptake), and increases again in the autumn (continued mineralization without crop uptake; Harmsen and Van Schreven 1955). This pattern does not hold for Southwestern soils. The factors discussed above suggest that the values of field life calculated above probably represent maximum values. We should also point out that modern Midwestern maize grows to an average height of $2.3 \mathrm{~m}$ and Southwestern Native American maize accessions, to which abundant fertilizer and water are added (Adams et al. 2006), produce blue and white varieties of Hopi maize that reach mean heights of 2.35 and $2.03 \mathrm{~m}$. However, under rain-on-field conditions, blue and white flour varieties of Hopi maize only reach a height of $\sim 1.3 \mathrm{~m}$ (Brown et al. 1952; Soleri and Smith 1995). This would suggest that hydrologic and nutrient stress factors in the American Southwest do not allow the maize plant to flourish.

In terms of grain yield, archaeological maize was much less productive than present-day Southwestern Native American maize when the latter receives abundant fertilizer and water. Hopi blue and white maize grown under optimal environmental conditions have mean cob diameters and lengths of, respectively, 4.2 and $\sim 18.3 \mathrm{~cm}$ (Adams et al. 2006). In contrast, unburned archaeological cobs are much smaller; for example, 20 cobs from Chaco Canyon archaeological contexts have an average diameter of $2.0 \mathrm{~cm}$ and an average length of $7.1 \mathrm{~cm}$ (L. Benson, unpublished data). If we treat the cobs as cylinders, the lateral surface areas of the cobs grown under optimal conditions are 5.4 times the lateral surface areas of the archaeological cobs, implying that on a cob-for-cob basis, the former produce much more grain than the latter. This suggests that archaeological maize was usually much smaller and much less productive than modern hybrid and Southwestern Native American maize, both of which have received abundant water and fertilizer (Adams et al. 2006).

Thus, the productivity of archaeological field systems may, in general, have been substantially $<10 \mathrm{bu} / \mathrm{ac}$ when 2,000 plants were grown. For example, Muenchrath et al. (2002) documented that the Zuni in 1998 produced an average yield of $12.2 \mathrm{bu} / \mathrm{ac}$ from three fields, having an average plant density of $\sim 4850$ plants/ac or almost 2.5 times the plant density used in the preceding calculations.

\section{Nitrogen Sources}

How is the soil $\mathrm{N}$ reservoir replenished in the study area? Zuni agricultural practices provide an example of sustainable agriculture within the southern part of the study 
area. The Zuni practiced runoff (ak-chin) farming (Brandt 1995; Ferguson and Hart 1985; Muenchrath et al. 2002) on valley margin alluvial fans and mesa footslopes where storm waters from upland watersheds were diverted to fields and managed using earthen and wooden berms as well as shallow ditches (Muenchrath et al. 2002). Cushing (1920) described an example of runoff farming at Zuni that took place in the late 1800s. Clearing of the field took 2 years. In the first year, the field was outlined with a ridge of soil and the existing vegetation was cut and burned in the center of the field. Low brush and earthen dams were constructed perpendicular to the slope of the upper part and center of the field. These structures acted to deflect and spread runoff as it flowed downward across the field (Cushing 1920).

Jon Sandor and his colleagues, in a series of seminal biogeochemical studies (Homburg et al. 2005; Norton et al. 2003, Norton et al. 2007a, b; Sandor et al. 2007), have described the transport and transformation of N-containing organic matter in three watershed field systems in the Zuni Reservation, New Mexico. Zuni fields are located at relatively high elevations in order to balance the freeze-free period with precipitation requirements. Watershed/field ratios average about 20-25:1 in the Zuni field systems. Zuni winters and early springs are characterized by frequent freeze-thaw cycles that cause microbial and physical breakdown of forest litter, and wet-dry cycles that occur in early summer enhance decomposition of organic matter accumulated on the alluvial fan since the previous rainy season. Simply put, sediments and organic debris, mainly derived from the high-elevation parts of the watersheds, are transported in runoff pulses down side-valley alluvial fan systems to field sites. The organic-rich sediments eventually arrive at the fields in various stages of decomposition with lower intensity precipitation-runoff events transporting higher quality, more decomposed organic matter. Thus, organic $\mathrm{N}$ is sporadically transported to Zuni fields via ephemeral side-tributary fan systems.

But what is the source of the $\mathrm{N}$ consumed by the plants that supply the organic matter to the alluvial fan systems? Norton et al. (2007a) demonstrated that sediments associated with oak, pinyon, and juniper trees contained substantial amounts of organic C (40-80 g/kg); however, these plants must originally obtain the $\mathrm{N}$ they need to grow from some other source. White and Thomas (1999) found that $\mathrm{N}$ in Zuni precipitation ranges from only 0.1 to $0.5 \mathrm{mg} / \mathrm{L}$ and Sandor et al. (2007) suggested that frequent lightning storms that characterize the Zuni region may fix substantial amounts of $\mathrm{N}$.

With respect to the White and Thomas (1999) study, precipitation falling in the western USA contributes $0.4-1.2 \mathrm{~kg} \mathrm{~N}$ per acre annually; however, human activities account for more that $90 \%$ of $\mathrm{NO}_{x}\left(\mathrm{NO}+\mathrm{NO}_{2}\right)$ emissions (Porter et al. 2000). Thus, the $0.1-0.5 \mathrm{mg} / \mathrm{L} \mathrm{N}$ value reported by White and Thomas (1999) probably is not representative of preindustrial $\mathrm{N}$ concentrations.

Estimation of $\mathrm{NO}_{x}$ production by lightning $\left(\mathrm{LNO}_{x}\right)$ remains a difficult task. Recently published studies indicate that $\mathrm{N}$ production rates vary between 0.9 (Nesbitt et al. 2000) and 12.2 $T_{\mathrm{g}} \mathrm{N} /$ year (Price et al. 1997); however, most studies estimate the total $\mathrm{LNO}_{x}$ value to be close to $5 T_{\mathrm{g}} \mathrm{N} /$ year (see, e.g., Huntrieser et al. 1998; Tie et al. 2002; Wang et al. 1998). The $5 T_{\mathrm{g}} \mathrm{N} /$ year value amounts to a $\mathrm{N}$ deposition rate of $0.14 \mathrm{~kg} / \mathrm{ac}$ on land surface - if lightning occurs only over land and if the $\mathrm{N}$ is completely rained out. This value is consistent with the value of the nonanthropogenic fraction of $\mathrm{N}$ in precipitation falling in the western USA. 
Given that a 10-bu/ac maize crop extracts from 5.8 to $6.6 \mathrm{~kg} \mathrm{~N}$ per year, lightning could only replace $<2 \%$ of the $\mathrm{N}$ consumed by 10 bu of maize. Thus, we must seek another source of $\mathrm{N}$. The best $\mathrm{N}$ source candidates are $\mathrm{N}$-fixing plants, e.g., Lupinus spp. (lupine), Purshia tridentata (antelope bitterbrush), and Cercocarpus montanus (mountain mahogany), which are common to the pinyon-juniper forests of the semiarid West. A recent study by Smith (2004) has demonstrated that litter decomposition of Purshia leaves contribute from 3.2 to $26.3 \mathrm{~kg}$ N per acre per year at Mesa Verde National Park. In addition, free-living cyanobacteria in Cryptobiotic crusts contribute between 3.6 and $16.6 \mathrm{~kg} \mathrm{~N}$ per acre per year to old pinyon-juniper woodlands in the Four Corners area (Belnap 2002; Evans and Ehleringer 1993; West 1990). It is therefore suggested that N-fixing plants comprise the ultimate source(s) of $\mathrm{N}$ transported to maize fields in the overall study area.

\section{Salinities of Study Area Soils}

EC measurements by the National Resources Conservation Services laboratory on saturated soil pastes (U.S. Department of Agriculture 2009) were used to construct an EC contour plot for the study area. The plot (Fig. 16a and ESM Table 2) indicates that surface salinity does not restrict the growing of maize within most of the study area $(\mathrm{EC}<1.5 \mathrm{dS} / \mathrm{m})$. Note that the elevated $\mathrm{EC}$ values contoured in the far western, northeastern, and southeastern parts of the study area are not well constrained by data (ESM Fig. 2).

The salinities of surface soils do not tell the full story in that the ECs of many of the soils increase rapidly with depth (Fig. 17 and ESM Table 2). A contour plot of EC at a depth of $\sim 1 \mathrm{~m}$ (Fig. 16b and ESM Table 2) indicates that the deeper soils at many pedon sites would restrict maize growth in the study area. In particular, a region running diagonally from northwest to southeast across the Four Corners contains very saline $(>5 \mathrm{dS} / \mathrm{m})$ soils at depth.
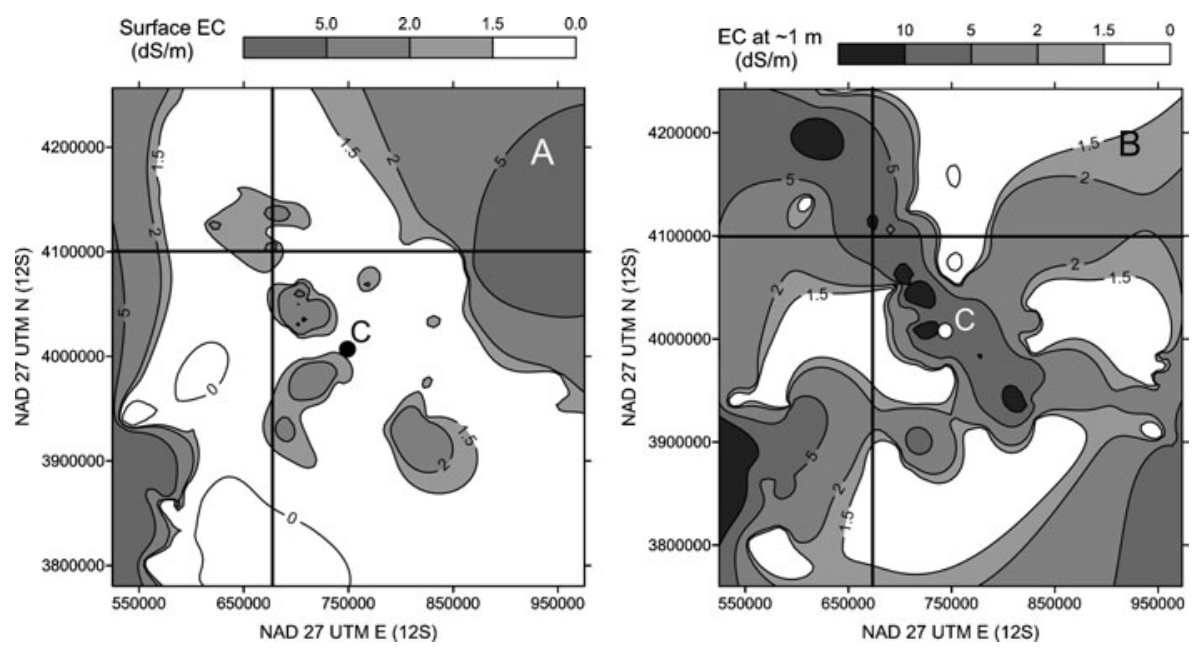

Fig. 16 Contour plots of electrical conductivity of soils in the study area at depths of near zero (a) and $1 \mathrm{~m}$ (b). C Chaco Canyon 


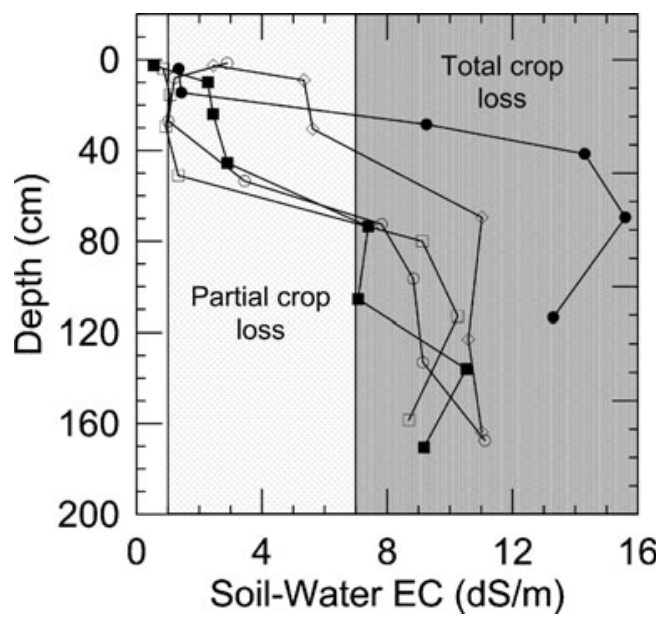

Fig. 17 Plots of typical soil electrical conductivity $(E C)$ profiles from soil pedons within the study area

Of the 140 soil pedon sites that have EC profiles that reach below $0.5 \mathrm{~m}, 105$ (75\%) indicate a substantial increase in EC with depth. To avoid such high-salinity zones, the roots of maize would have to extend themselves laterally, confining themselves to an upper low-salinity zone. This may be one reason that Southwestern Native Americans landraces were planted in widely spaced hills. If the roots of maize are restricted to the upper half meter of the root cone, i.e., the overall root mass is confined to a frustum with radii of 1.2 and $0.6 \mathrm{~m}$ and a height of $0.5 \mathrm{~m}$, the volume of the root ball is reduced to $1.32 \mathrm{~m}^{3}$. This would entail a loss of $13 \%$ of the initially available organic $\mathrm{N}$ and implies that even fewer regions in the study area were able to produce $10 \mathrm{bu} / \mathrm{ac}$ of grain via dryland farming.

\section{The pH of Study Area Soils}

Determinations of soil $\mathrm{pH}$ are usually done on a saturated paste or on a 1:1 soil/ deionized water solution that is left standing for $1 \mathrm{~h}$ before measurement. All measurements in this paper are relative to the 1:1 solution. Correction of saturated paste to $1: 1 \mathrm{pH}$ values was done using the relationship indicated in Fig. 18 (ESM Table 2). A soil surface $\mathrm{pH}$ contour map (Fig. 19a and ESM Table 2), based on 298 soil samples (U.S. Department of Agriculture 2009) collected from the study area, indicates that few sites in the study area possess a $\mathrm{pH}$ that is optimal for maize growing; for example, the entire central San Juan Basin is associated with elevated $\mathrm{pH}$ values $(>8.5)$.

There is a tendency for $\mathrm{pH}$ to increase with depth in many of the soil pedons; $72 \%$ of the pedons $(n=246)$ had $1-\mathrm{m} \mathrm{pH}$ values that exceeded surface $\mathrm{pH}$ values. Soil $\mathrm{pH}$ values from a depth of $\sim 1 \mathrm{~m}$ are concentrated within the 7.5 to $9.0 \mathrm{pH}$ interval (Fig. 20b and ESM Table 2), whereas surface soils have relatively more values in the 5.0 to $7.5 \mathrm{pH}$ range (Fig. 20a and ESM Table 2). A contour plot of soil $\mathrm{pH}$ values from $\sim 1-\mathrm{m}$ depth $(n=251)$ indicates that all but the mountainous northeastern region of the study area have elevated $\mathrm{pH}$ values (Fig. 19b and ESM Table 2) outside the optimum range $(\mathrm{pH} 6.0-6.5)$ for $\mathrm{P}$ availability $\left(P_{\mathrm{AV}}\right)$. 


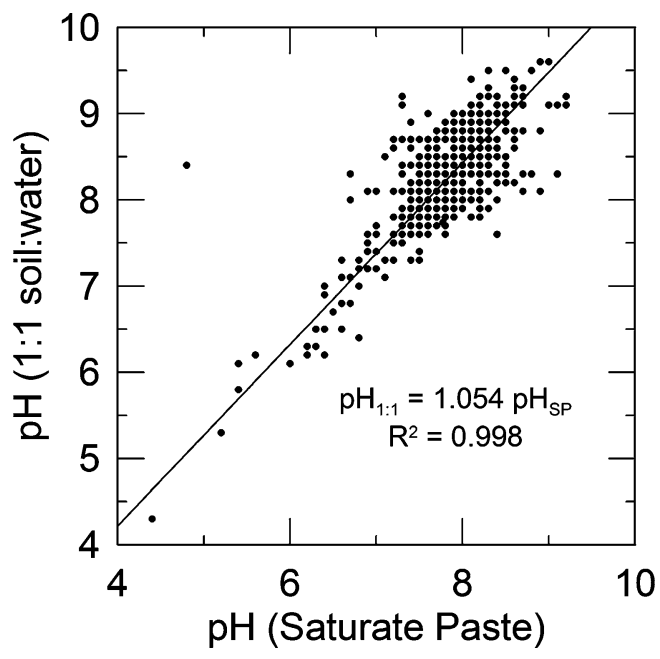

Fig. 18 Correlation of $\mathrm{pH}$ measurements on saturated soil pastes $\left(\mathrm{pH}_{S P}\right)$ with $\mathrm{pH}$ measurements on 1:1 (soil/water) solutions $\left(\mathrm{pH}_{1: 1}\right)$

Approximately $60 \%$ of these samples have $\mathrm{pH}$ values outside the optimum range of $\mathrm{N}$ availability ( $N_{\mathrm{AV}}$; Fig. $20 \mathrm{~b}$ and ESM Table 2$)$.

\section{Native American Practices Designed to Optimize Maize Yields}

In the following, Native American practices of water diversion, water concentration, evapotranspiration mitigation, and planting that were designed to optimize the growing of maize in a semiarid agricultural environment are discussed. In this paper,

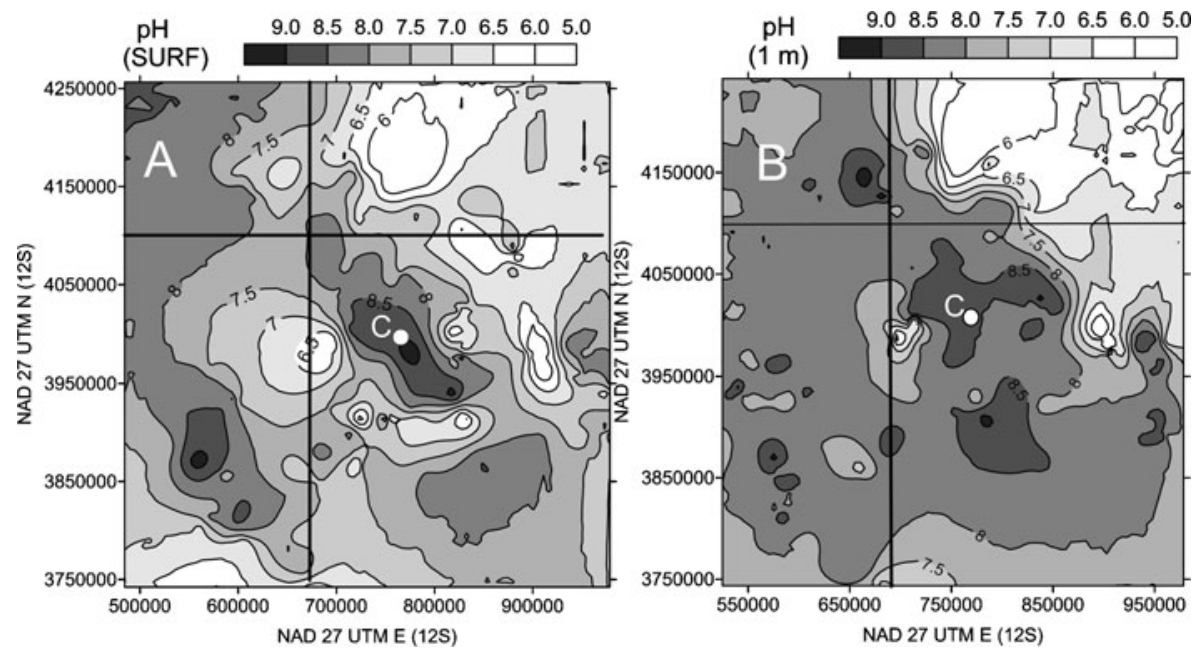

Fig. 19 Contour plots of the pH of surface soils (a) and 1-m soils (b) in soil pedons within the study area. $C$ Chaco Canyon 

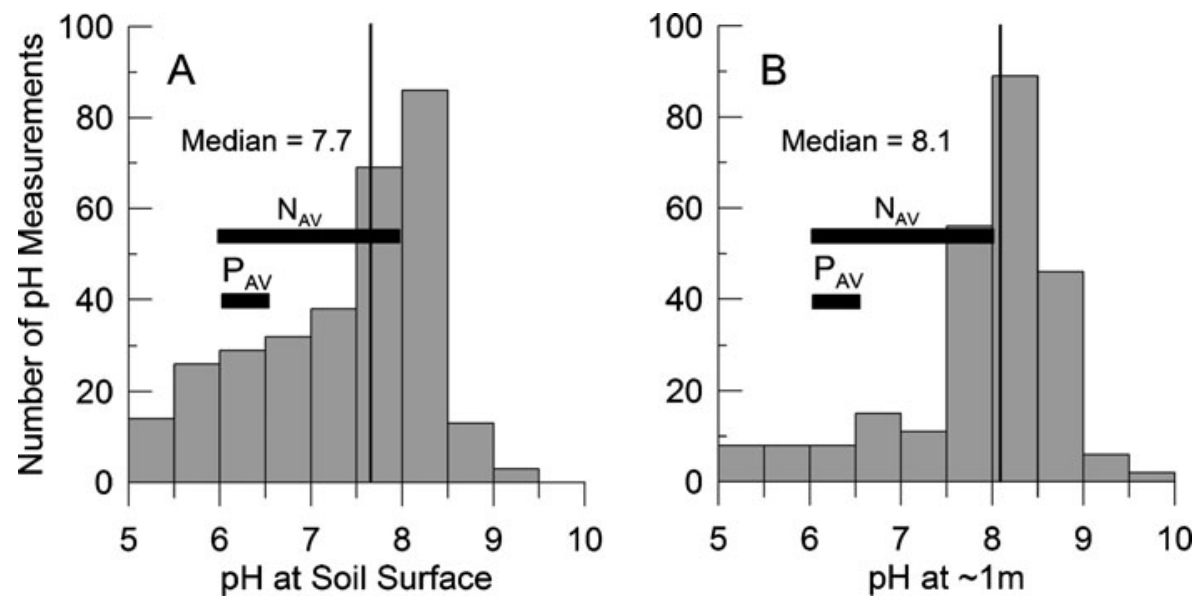

Fig. 20 Histograms of $\mathrm{pH}$ in surface soils (a) and 1-m soils (b) in soil pedons within the study area. $N_{\mathrm{AV}}$ indicates the range of $\mathrm{pH}$ values that promote the biological availability of $\mathrm{N}$, and $P_{\mathrm{AV}}$ indicates the range of $\mathrm{pH}$ values that promote the biological availability of $\mathrm{P}$

we have discussed several environmental factors that cause dryland farming of maize in the Southwest to be a risk-filled venture. Because of this risk, Native American farmers sited their fields across different soil types and landforms. Given that the raising of maize by Southwestern Native Americans is a matter of record (see, e.g., Huckell 2006; Vierra and Ford 2006), how did prehistoric and early historic Southwestern Native Americans produce maize given the paucity and patchiness of intense precipitation events during high-evaporation summers and the limited amount of precipitation that fell in the winter?

\section{Water Diversion and Concentration}

One answer to the problem posed by inadequate precipitation is water diversion and concentration strategies that were mostly applied to summer precipitation events. As mentioned previously, a summer rainfall of $15 \mathrm{~cm}$ and an annual precipitation of $30 \mathrm{~cm}$ are considered the approximate lower limits for maize production (Shaw 1988); however, maize yields can be radically improved by increasing the amount of water added to a field (Fig. 21).

Masse (1980) noted that Hohokam dry farming included the use of check dams and contour terraces at the Gu Achi site in Arizona, and Woodbury (1961) found that the Mogollon people in the Point of Pines area, Arizona constructed terraces perpendicular to hillside slopes to slow runoff and trap soil. The Hopi practice runoff (ak-chin) farming at the mouth of arroyos cut into side-valley alluvial fans. At the arroyo mouth, sand is deposited in the form of a shallow fan where runoff from the arroyo's watershed spreads out. Hopi farmers divert the water to other field areas using earthen dikes and ditches (Hack 1942). The Zunis commonly irrigated maize fields near farming villages using spring-fed ditches and also practiced ak-chin farming at distant sites. In the Pajarito Plateau, the most common agricultural practice was to create fields on gently sloping mesa tops where maize 


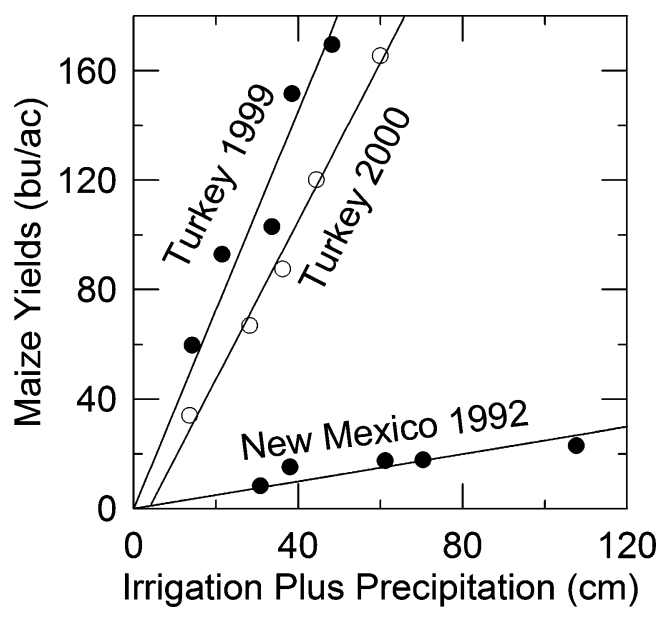

Fig. 21 Maize yields as a function of water received by agricultural fields in New Mexico (Adams et al. 1999) and Turkey (Mengü and Özgürel 2008)

relied directly on precipitation; however, the prehistoric Native Americans in this area also built contour terraces and check dams to slow runoff (Gauthier and Herhahn 2005).

\section{Evaporation Mitigation}

Bare soil evaporation $\left(O_{\mathrm{E}}\right)$ can be reduced by spreading mulch between maize hills; for example, putting straw on the soil surface may reduce the evaporation by up to $30 \%$ in no-tillage agriculture as opposed to conventional tillage (Morote et al. 1990; Salton and Mielniczuk 1995). Hopi and Zuni farmers leave stubble from harvested crops in the field, which functions as vegetative mulch, slowing runoff, promoting the infiltration of water, and preventing the growth of weeds.

Lithic mulches moderate the soil temperature beneath the stones and decrease the wind speed over the soil, thereby decreasing the rate of evaporation (Benoit and Kirkham 1963; Lightfoot and Eddy 1994). In the Galisteo Basin of New Mexico, Lightfoot (1990) documented 96 pebble-mulched fields covering a total area of $0.41 \mathrm{~km}^{2}$. Choriki et al. (1964) have demonstrated, over a 2-year period, that 30 $40 \%$ more water is stored in a gravel-mulched soil compared to a bare soil. Homburg (2000) has shown that the upper $10 \mathrm{~cm}$ of gridded fields, in the Safford Basin of southeast Arizona, average about twice the moisture relative to areas outside the grids. In addition, the use of lithic mulch also optimizes the infiltration of rainfall and overland flow and may act as a mini snow fence that increases the infiltration of winter precipitation.

The prehistoric Native Americans that inhabited the Pajarito Plateau planted gardens bordered by rocks that slowed erosion and retained moisture, and they mulched some of the gardens with gravel to conserve moisture and protect plants from killing frosts (Gauthier and Herhahn 2005). Maize was often planted in pumice deposits which absorb and hold moisture and which also act as mulch, slowing evaporation and keeping the deeper soil cooler. 
Excepting large shrubs, only the bases of small plants are hoed by the Hopi when preparing a field, thus leaving the rest of the bare soil undisturbed. This renders the surface soil less subject to erosion (Prevost et al. 1984) and also conserves soil moisture (Ford 1985). In essence, this is a form of no-till farming. However, leaving the bare soil undisturbed decreases the infiltration rate of precipitation and run-on; for example, no-till treatment was found to reduce the saturated hydraulic conductivity of surface soil by a factor of six times in experimental fields near Prague, Czech Republic (Matula 2003). Planting squash, which covers bare soil between maize hills, also lessens bare soil evaporation (Berzok 2005:49).

\section{Weed Reduction}

With respect to water stored in and transpired from weeds $\left(O_{\mathrm{T}, \mathrm{W}}\right)$, traditional farming practices of the Hopi and Zuni eliminate all plants other than the crop prior to planting (Cushing 1920; Underhill 1946). The Zuni collected the vegetation in the center of the field and burned it, whereas the Hopi removed large vegetation to the edge of the field before burning (Cushing 1920; Dominguez and Kolm 2005 and references therein). Transpiration losses via weeds are minimized by frequent weeding of Hopi fields (Dominguez and Kolm 2005; Forde 1931; Stewart 1940). Weed management is not today considered an important activity by the Zuni (Muenchrath et al. 2002); however, most Zuni farmers occasionally hoe and pull weeds. The importance of weeding in recent times has been documented in a study in the Crisurilor Plain of Romania in which Borza (2008) showed that the growth of weeds lowered maize yields by $54 \%, 47 \%$, and $86 \%$ in 2005,2006 , and 2007 , respectively.

\section{Maize Fertilization by Southwestern Native Americans?}

Brandt (1995) has noted that "Burning brush, when clearing a field, and catching nutrient-laden sediment from water and the wind are the only references in early ethnographic accounts to fertilizing fields," and Arrhenius (1963) stated that Southwestern American Indians did not appear to "have been acquainted with the use of natural manure as a means of improving the soil." Beaglehole (1937) observed that the Hopi farmer had no set system of crop rotation nor did he make use of animal manure. Farmers did not apply the manure of livestock on Zuni fields until encouraged by agricultural extension workers in the 1920s (MacDowell 1919). Thus, there is little evidence for early or prehistoric Zuni or Hopi fertilization of maize.

Adams (2004), however, has documented two types of southwestern Native American practices (adding fireplace ash and human urine to fields) which may indicate fertilization. Adam's examples of possible maize fertilization include the following anecdotes: (1) Stevenson (1915) recorded that the Zuni took 10 days of ashes and sweepings to the fields; (2) the Zia are known to pack wood ashes around the bases of maize sprouts (Euler 1954); (3) in the mid 1500s, Castenada documented the collection of urine in clay vessels by Puebloans who emptied the vessels some distance from the pueblos (Hodge 1946); and (4) the implication that 
the urine was added to agricultural fields is supported by Bandelier who reported the same practice 300 years later and commented that the urine was carried "out into the fields" (Lang and Riley 1966:104).

How effective is adding wood ash and human urine to agricultural fields in the southwestern USA, and did the intercropping of beans with maize extend the fertility of Native American fields?

\section{Addition of Wood Ash to Native American Fields}

As stated previously, $\mathrm{N}$ and $\mathrm{P}$ are most accessible to maize within a $\mathrm{pH}$ range of 6.06.5. A compilation of 37 wood ash samples (Risse 2002 and references therein) indicates that the $\mathrm{pH}$ of wood ash ranges from 9.0 to 13.5 , with an average $\mathrm{pH}$ value of 10.4. The 37 ash samples have average $\mathrm{Ca}, \mathrm{K}, \mathrm{P}$, and $\mathrm{N}$ concentrations, respectively, of $15 \%, 2.6 \%, 0.53 \%$, and $0.15 \%$. One analysis of juniper ash (a tree common to the Southwest) indicates a composition of $26.5 \% \mathrm{Ca}, 7.9 \% \mathrm{~K}$, and $2.1 \%$ P (U.S. Patent Application 20040126460).

The $\mathrm{K}$ and $\mathrm{P}$ content of wood ash makes it an attractive amendment; however, the elevated $\mathrm{pH}$ and $\mathrm{Ca}$ values indicate that application of wood ash only benefits acidic soils. In fact, Aleksandrovskii (2007) has reported that both potash $\left(\mathrm{K}_{2} \mathrm{CO}_{3}\right)$ and calcite $\left(\mathrm{CaCO}_{3}\right)$, which increase the alkalinity of the soil, are produced during organic matter incineration.

Soils with a $\mathrm{pH}<5.5$ will likely be improved by wood ash addition, and soils that are slightly acidic ( $\mathrm{pH} 6.0-6.5$ ) should not be harmed by the application of 3,950 kg/ ac annually if the ash is worked into the top $15 \mathrm{~cm}$ of soil (Lerner 2000). A soil surface pH contour map, based on 298 soil samples (U.S. Department of Agriculture 2009) collected from the study area (Fig. 19), indicates that few sites in the study area have a $\mathrm{pH}$ that would benefit from the addition of wood ash.

The more complete the combustion of wood, the greater is the amount of $\mathrm{N}$ volatized. Thus, the addition of wood ash does little to increase the $\mathrm{N}$ content of a soil. Increasing the soil $\mathrm{pH}$ by adding wood ash also will adversely affect the transformation of organic $\mathrm{N}$ to biologically available $\mathrm{NO}_{3}$ and will also increase $\mathrm{N}$ volatility, especially when urine is the $\mathrm{N}$ source. Rao and Batra (1983) observed that $62 \%$ of the $\mathrm{N}$ was lost, via volatilization, when ammonium sulfate was applied to an alkali soil with a $\mathrm{pH}$ of 10.2 , whereas only $0.2 \%$ was lost when $\mathrm{N}$ was applied to a soil having a $\mathrm{pH}$ of 7.8 .

With respect to burning fields to fertilize them, fire chemically stimulates mineralization of soil organic matter to $\mathrm{NH}_{4}{ }^{+}$, much of which the highly alkaline ash left behind converts to $\mathrm{NH}_{3}$ gas, which is subsequently lost to the atmosphere. During burning, fire converts most of the $\mathrm{N}$ in the vegetation to $\mathrm{N}_{2}$ gas, which is also lost to the atmosphere (Raison et al. 1985).

It has been noted that few soils in the study area would have benefited from the addition of wood ash; however, for those high-elevation fields with slightly acidic soils, a calculation will be made with regard to the amount of wood that must be burned to provide the necessary ash. The amount of ash that should be added to a soil is dependent on the $\mathrm{pH}$ of the soil; however, for the calculations that follow, we will follow Lerner's (2000) suggestion that soils that are slightly acidic (pH 6.0-6.5) should not be harmed by the application of $3,950 \mathrm{~kg}$ ash/ac annually. Such 
calculations apply to relatively wet and wooded environments that exist in forested high-elevation parts of the study area.

Given that wood burning produces 6-10\% ash (Risse 2002), more than $39,500 \mathrm{~kg}$ of wood would have to be burned to fertilize the entire surface of a 1-ac field. If, instead, 440 hills of maize were each surrounded by a 1-m diameter circle of ash, only $4,290 \mathrm{~kg} / \mathrm{ac}$ of ash would be needed. The latter amount of ash could be supplied, for example, by burning 250 juniper trees with 10 - to $20-\mathrm{cm}$ diameters (Miller et al. 1981), which is equivalent to the burning 3.5 cords of dry Utah juniper.

Van Epps et al. (1982) reported an average plant dry weight of $15.9 \mathrm{~kg}$ for big sagebrush from four sites in the Intermountain western USA. Big sagebrush has a plant density of 1316 plants/ac and produces an average of $3.1 \%$ ash. To produce $4,290 \mathrm{~kg}$ of ash from big sagebrush, 8,700 plants $(6.6 \mathrm{ac})$ would have to be cleared and burned.

Stephen (1936) recorded that $314 \mathrm{~kg}$ (12.4 bu) of maize was consumed annually by an individual Hopi. This figure seems exaggerated, given that a kilogram of maize contains about 3,500 kcal (Dietz et al. 2001; Salvador 1997). An individual that ingested $314 \mathrm{~kg}$ of dried maize in a year would consume 3,000 kcal/day from maize alone, which seems extraordinarily high; for example, rural Mesoamericans consume between 95 and $161 \mathrm{~kg}$ of dried maize per year (940-1,590 kcal/day; Stuart 1990). If we assume an average consumption of $128 \mathrm{~kg}$ of grain per person per year, this implies that a family of six would consume $30 \mathrm{bu}$ of maize annually. If an acre field yielded 10 bu of maize, a Native American family would have to burn at least 10.5 cords of juniper or 26,100 big sage plants to supply the ash necessary to amend the three acres.

\section{Addition of Human Manures}

With respect to human manures, the application of urine to agricultural fields has a number of drawbacks. Maize can tolerate a high concentration of $\mathrm{N}$ and responds well to the application of a 3:1 mix of water and urine (Morgan 2007); however, if undiluted urine is applied to maize, it can cause foliar burns.

Urine is rapidly attacked by soil organisms, leading to the formation of ammonium hydroxide which transforms to ammonia $\left(\mathrm{NH}_{3}\right)$, which is lost through volatilization or is converted by bacteria to $\mathrm{NO}_{3}-\mathrm{N}$ (nitrification). Bear and Royston (1919) found that urine exposed to air lost $92 \%$ of its $\mathrm{N}$ in 12 weeks at a temperature of $32.5^{\circ} \mathrm{C}$, and Sommer et al. (1991) found that $55 \%$ of the ammonia in urine was lost in 2 days. Fertilizer losses from surface-applied urea can result in ammonia loss via volatilization in excess of $43 \%$ (Fowler and Brydon 1989). Therefore, urine needs to be diluted with water and worked into the soil if a crop is to receive the maximum benefit of the urine's $\mathrm{N}$ content. There is no evidence of this practice in the early or prehistoric Southwest.

Approximately $1.5 \mathrm{~L}$ of urine is released from an adult each day (Rauch et al. 2003). The annual production of $\mathrm{N}$ in urine by an individual has been estimated to be $4.00 \mathrm{~kg}$ by Vinneras (2002) and $4.02 \mathrm{~kg}$ by Esrey et al. (2000). These values may be overestimates of the $\mathrm{N}$ concentration in prehistoric human urine as modern humans eat a protein-rich diet. Thus, the amount of urine produced by a person in 
the first 90 days of a 120-day growing season (the time range over which fertilizer could be profitably added to a field) totals about $1.0 \mathrm{~kg}$.

Calculations using the data contained in Tables 2 and 4 indicate that aboveground maize plants in a 1-ac field, containing 440 hills, with an average of 4.5 plants/hill, would contain 5.8 to 6.6 times more $\mathrm{N}$ than produced by one human in a 90 -day fertilization period. In addition, this calculation does not account for $\mathrm{N}$ loss associated with the volatilization of $\mathrm{NH}_{3}$ and $\mathrm{N}_{2}$ from urine spread on the field. If, for example, $50 \%$ of the urine added to a field is lost via $\mathrm{N}$ volatilization, then an individual could supply only about $7.5 \%$ of the $\mathrm{N}$ necessary to fertilize $10 \mathrm{bu}$ of grain.

A person produces only about $0.55 \mathrm{~kg} \mathrm{~N}$ in 1 year's feces (Vinneras 2002). This constitutes only $13.8 \%$ of the $\mathrm{N}$ produced in 1 year's urine. Little $\mathrm{N}$ benefit could be achieved by applying human feces to a maize field, unless it was done throughout the year and the feces were turned into the soil. Generally speaking, from $25 \%$ to $50 \%$ of the organic $\mathrm{N}$ in manure is released to the soil during the first year (DeLoughery and Wortmann 2005), in which case the amount of manure produced in a year would contribute $<28 \%$ of the $\mathrm{N}$ input by urine during the first 90 days of the growing season.

\section{The Nitrogen-Fixing Efficiency of Beans}

Much has been made of the "three sisters" of Native American agriculture: maize, beans, and squash. When the maize reaches $15 \mathrm{~cm}$, beans and squash are planted around the maize stalk(s). In theory, the maize provides the "pole" for the beans to climb, the squash spreads over the ground and acts as a vegetative mulch, and the beans provide $\mathrm{N}$ to the soil (Berzok 2005).

Biological $\mathrm{N}$ fixation is a process that reduces inert $\mathrm{N}$ gas $\left(\mathrm{N}_{2}\right)$ to ammonia $\left(\mathrm{NH}_{3}\right)$, which is used by the plant to manufacture amino acids and proteins. Common beans are poor $\mathrm{N}$ fixers $(<23 \mathrm{~kg} / \mathrm{ac})$ and fix less $\mathrm{N}$ than their $\mathrm{N}$ needs. Almost all the $\mathrm{N}$ fixed is incorporated in the plant with little leaking into the soil. Stalks, leaves, and roots of beans contain about the same concentration of $\mathrm{N}$ found in non-legume crop residue such as maize stover. Roots and crowns of legumes add little soil $\mathrm{N}$ compared to the $\mathrm{N}$ contained in the aboveground biomass (Lindemann and Glover 2003). In fact, the residue (stover) from a maize crop contains more $\mathrm{N}$ than the residue from a bean crop.

Annual legumes such as beans do not contribute $\mathrm{N}$ to the soil because most of the fixed $\mathrm{N}$ is in the seed; therefore, for beans to contribute $\mathrm{N}$ to the soil, they must be turned under the soil as green manure before they are in full bloom (Parnes 1990). In one study involving field beans, $173 \mathrm{~kg} \mathrm{~N}$ per hectare were contained in the plant, $48 \mathrm{~kg}$ had been fixed from the atmosphere, and $98 \mathrm{~kg}$ was removed in the grain; thus, $50 \mathrm{~kg}$ of $\mathrm{N}$ was lost to the grain from the soil (Haynes et al. 1993).

\section{Advantages and Disadvantages of Planting Multiple Seeds in Widely Spaced Hills}

There are some disadvantages to planting maize in widely spaced hills. By planting four to five plants in a single hill, a need is created for four to five times the nutrient and water loading normally accessed by a single root volume. This is especially critical with respect to $\mathrm{P}$ which has a very low solubility in the aqueous phase, 
especially at a $\mathrm{pH}>7$ when $\mathrm{Ca}^{2+}$ reacts with $\mathrm{PO}_{4}{ }^{3-}$ to form insoluble phosphate compounds (see, e.g., Fig. 12.8 in Lindsay 1979). Because P is relatively immobile in the soil water, maize roots and fungal hyphae are only able to access $\mathrm{P}$ located adjacent to them; that is, they are not be able to draw in P from areas outside the area surrounding individual roots.

On the other hand, the production of multiple ears per plant is favored where low plant density reduces shading by maize rows (Hallauer and Troyer 1972). Muenchrath and Salvador (1995) have suggested that the tendency of Southwestern maize cultivars to produce multiple ears is an adaptive mechanism that occurred in response to a stressful environment. Muenchrath and Salvador (1995) also have pointed out that planting in hills promotes more rapid plant emergence than planting in rows.

Maize pollen is spherical and relatively large and falls to the ground rapidly ( $30 \mathrm{~cm} / \mathrm{s}$; Thomison 2009). Byrne et al. (2003) has shown, using adjacent fields planted in differing maize types, that cross-pollination occurred in $\sim 50 \%$ of the maize located within $1 \mathrm{~m}$ of the boundary between fields and that only $0.2-0.8 \%$ of the maize indicated cross-pollination $50 \mathrm{~m}$ from the boundary. Thus, within-hill pollination of maize (from tassel to ear shoot) becomes more efficient when multiple plants are grown together.

Lastly, clustering of plants in hills helps anchor the plants and keeps them from tipping over in the relatively loose Southwestern soils or breaking (lodging) during wind storms.

\section{Use of Optimally Structured Soils}

Most soils are not texturally uniform but consist of sediment layers that have contrasting hydraulic conductivities. Many Southwestern Native Americans took advantage of the case in which coarse-grained permeable sediment overlies finegrained impermeable sediment. In this case, the coarse-grained sediment acts as wet mulch and the fine-grained sediment slows infiltration of water through the soil zone. Hopi, Zuni, and Tohono O'odham farmers understand the importance of planting in fields that have relatively coarse surface sediments underlain by finegrained sediments (Bradfield 1971; Clark 1928; Nabhan 1984; Prevost et al. 1984). To quote Bradfield (1971:5) with regard to Hopi ak-chin farming practices "...the farmer first pushes the surface layer of sand to one side with his foot; he then goes down on one knee, scrapes a hole about 10 inches deep with his digging stick..., loosens the soil at the bottom for a further 2 to 3 inches..., drops the seed-12 to 15 individual kernels - into the hole; finally he pushes back the soil with his hand, first the clay-and-sand loam to fill the hole, then the covering of fine sand on top. This method of planting ensures that the seed itself lies well down in the moist subsoil."

\section{Summary}

1. Prehistoric and early historic Southwestern Native Americans raised four to five maize plants per hill. The mean field density was about 2,000 plants/ac. 
2. Prehistoric Native American cobs from the study area are much smaller than modern cobs produced under optimum (water and nutrients) conditions. This suggests that prehistoric maize production may have been much less than $10 \mathrm{bu} / \mathrm{ac}$.

3. To flourish maize requires an adequate supply of water, heat, and nutrients as well as a well-structured soil.

4. Fifteen centimeters of summer and $30 \mathrm{~cm}$ of annual precipitation represent, respectively, the minimum amounts of precipitation for dryland (rain-on-field) farming of maize.

5. Eight thousand seven hundred fifty kilograms of water is transpired for every bushel of grain produced.

6. An equivalent depth of $13.4 \mathrm{~cm}$ of water must be supplied to the root volume occupied by 4.5 maize plants to allow the production of $10 \mathrm{bu}$ per acre of maize.

7. Study area contour plots of precipitation indicate that northwestern New Mexico and northeastern Arizona are deficient in both summer and annual precipitation with regard to the dryland production of maize.

8. About $1 \mathrm{~cm}$ of water can be rapidly evaporated from the wetted surface of a soil during the summer when the bare soil evaporation rate ranges from 5 to $8 \mathrm{~mm} /$ day.

9. The rate of maize growth is directly proportional to the amount of solar radiation absorbed.

10. Most maize varieties, including some Southwestern Native American landraces, require $\sim 120$ freeze-free days and at least 1,000 growing degree days.

11. Study area contour plots of growing degree days suggest that much of the San Juan-La Plata mountain region in southwestern Colorado and the Sangre de Cristo mountain region in north-central New Mexico, as well as an area south of Chaco Canyon east of the New Mexico-Arizona border, is too cold for the production of maize.

12. Growing degree days should not greatly exceed 1,000 in the Southwest given that the extra heat increases bare soil evaporation.

13. Decomposition of dead organic matter releases nutrients to the soil necessary for plant and microbial production. The decomposition process consists of leaching, fragmentation, and chemical alteration.

14. Soil microbes that participate in the mineralization of organic $\mathrm{C}$ and $\mathrm{N}$ probably do not function optimally in the semiarid Southwest where the soil is relatively dry and saline.

15. Soil organic matter resists decomposition via biochemical recalcitrance, chemical stabilization, and physical protection.

16. An indefinite number of soil organic carbon pools characterized by differing rates of decomposition exist within a soil.

17. Most researchers divide soil organic carbon into labile, refractory, and intermediate pools. The labile pool has a turnover time ranging from months to a few years, and the refractory pool has a turnover time on the order of a few millennia. 
18. A simple way to distinguish labile and refractory soil organic carbon is to hydrolyze the soil organic carbon with hot $6 \mathrm{~N} \mathrm{HCl}$. The acid hydrolysis effectively dissolves the labile fraction.

19. The radiocarbon $\left({ }^{14} \mathrm{C}\right)$ age of non-hydrolyzable organic carbon generally increases with depth in a soil, and the amount of soil organic carbon generally decreases with depth.

20. Gross $\mathrm{C}$ mineralization rates are good predictors of gross $\mathrm{N}$ mineralization rates.

21. $\mathrm{N}$ mineralization rates generally decrease exponentially with depth in a soil, indicating that most $\mathrm{N}$ mineralization occurs in the upper $30 \mathrm{~cm}$ (plow zone).

22. Natural system $\mathrm{N}$ mineralization rates have been reported to range from 1.5 to $3.5 \%$ year; however, these rates probably were determined in relatively warm humid climates and may not be strictly applicable to the American Southwest. In addition, these rates were probably determined in studies of the upper $\leq 30 \mathrm{~cm}$ of soil where the most labile organic $\mathrm{N}$ occurs.

23. If a field dedicated to maize cultivation is not semi-continuously supplied with $\mathrm{N}$, the labile soil organic $\mathrm{N}$ pool will become depleted and the bulk $\mathrm{N}$ mineralization rate will decrease exponentially.

24. Maize can only extract nutrients from the soil volume occupied by its roots. This volume can be approximated by a cone with a diameter of $2.4 \mathrm{~m}$ and a height of $1 \mathrm{~m}$. Most of the root mass of modern maize lies within the top $30 \mathrm{~cm}$ of soil.

25. The first, second, and third quartile $\mathrm{N}$ values for the top $50 \mathrm{~cm}$ of soil in the study area are $0.035 \%, 0.059 \%$, and $0.111 \%$. Contours of organic C, which proxies for organic $\mathrm{N}$, indicate that the area southeast of the Four Corners including the San Juan Basin has organic N values which are less than the first quartile value. Only about $25 \%$ of the study area is capable of producing $10 \mathrm{bu}$ of maize per acre for any extended period of time.

26. Given that for a given volume of soil modern Midwestern maize plant densities require approximately seven times the nutrients consumed by early historic Southwestern fields, measured $\mathrm{NO}_{3}-\mathrm{N}$ and available $\mathrm{P}$ concentrations in Southwestern soils need only exceed values of 3-4 $\mu \mathrm{g} / \mathrm{g} \mathrm{NO}_{3}-\mathrm{N}$ and 1.5$2.0 \mu \mathrm{g} / \mathrm{g} P_{\mathrm{AV}}$ to produce a crop.

27. A pH range of 6.0-6.5 is optimal for $\mathrm{N}$ and $\mathrm{P}$ availability.

28. Study area contour plots of $\mathrm{pH}$ values at a depth of $1 \mathrm{~m}$ in the soil zone indicate that all but mountainous regions in the study area have elevated $(>8) \mathrm{pH}$ values, which are outside the range of optimum $\mathrm{N}$ and $\mathrm{P}$ availability.

29. When soil-water salinities exceed $1.5 \mathrm{dS} / \mathrm{M}$, maize begins to die and at a salinity of $7 \mathrm{dS} / \mathrm{M}$, complete crop loss occurs.

30. Nearly $75 \%$ of the soil pedon sites indicate an increase in salinity with depth such that roots cannot penetrate much below $50 \mathrm{~cm}$ or the maize plant will die.

31. In the historical period, a negative Pacific Decadal Oscillation and a positive Atlantic Multidecadal Oscillation have been associated with drought in the study area. Tree ring-based studies of prehistorical climate change also indicate that the mid-twelfth and late-thirteenth century megadroughts were associated with a negative Pacific Decadal Oscillation. 
32. Prehistoric fertilization of Native American fields with human waste or wood ash has not been clearly documented. In any case, the addition of human urine or feces falls short of supplying enough $\mathrm{N}$ to fertilize the amount of maize required to feed a Native American family of six. Most soils in the study area have $\mathrm{pH}$ values too high to accept wood ash, which itself has a $\mathrm{pH}$ ranging from 9 to 13.5 .

33. Despite statements to the contrary, the growing of common bean together with maize does not add to the amount of organic $\mathrm{N}$ stored in the soil. In fact, the bean plant consumes $50 \%$ of its $\mathrm{N}$ from the soil and 50\% from the air. Most of the $\mathrm{N}$ so obtained is contained within the seed itself; therefore, unless the bean is returned to the ground as green manure, there is a net loss of $\mathrm{N}$ from the soil when growing beans.

34. Early historic and presumably prehistoric Southwestern Native Americans employed several methods to improve dryland farming, including water concentration, evaporation mitigation, and weed reduction.

\section{Conclusions}

Water is the master variable throughout the study area. Water encourages the growth of $\mathrm{N}$-fixing plants such as bitterbrush, mountain mahogany, lupine, cryptobiotic crusts, and lichen. Without N-fixing plants, the organic $\mathrm{N}$ reservoir would soon be depleted due to loss of $\mathrm{NO}_{3}-\mathrm{N}, \mathrm{N}_{2}$, and $\mathrm{NH}_{3}$ from the soil zone. The $\mathrm{N}$-fixing plants support the growth of other plants and the overall plant community provides $\mathrm{N}$ containing organic matter to the soil. The mineralization rate of soil organic $\mathrm{N}$ is a function of soil moisture with higher moisture levels promoting more rapid mineralization rates (under oxidizing not anaerobic conditions). In addition, water is consumed during evapotranspiration that accompanies carbon fixation by the plant. Finally, the transport of abundant water through the soil zone prevents the buildup of salts, the latter which decrease the amount of plant-available water.

Generally speaking, the amounts of summer and winter moisture increase with increasing elevation in the study area (compare Fig. 1 with Fig. 11a, b). However, GDD decreases with elevation (Fig. 12) such that the elevational range permitting dryland farming changes from year to year (Petersen 1986).

Drought has been a reoccurring problem in the study area throughout the past 2,000 years. Megadroughts, defined as droughts that last 20 or more years, during which PDSI values are less than or equal to -1 at least $60 \%$ of the time, have occurred 12 times between A.D. 0 and A.D. 1600 (Fig. 22). Many of these droughts are associated with archaeological phase transitions and with demographic changes (Benson and Berry 2009), which probably reflect cultural responses to declines in the subsistence base.

In conclusion, the climate and soil chemical parameters discussed and illustrated in this paper (Figs. 11, 12, 14, 16, and 19) indicate that much of the study area could not and does not support a 10-bu/ac yield of maize. The San Juan Basin, including Chaco Canyon, appears to be the least promising area for dryland farming; that is, it is too dry and its soils are N-poor, saline, and too basic (high $\mathrm{pH}$ values) for the 

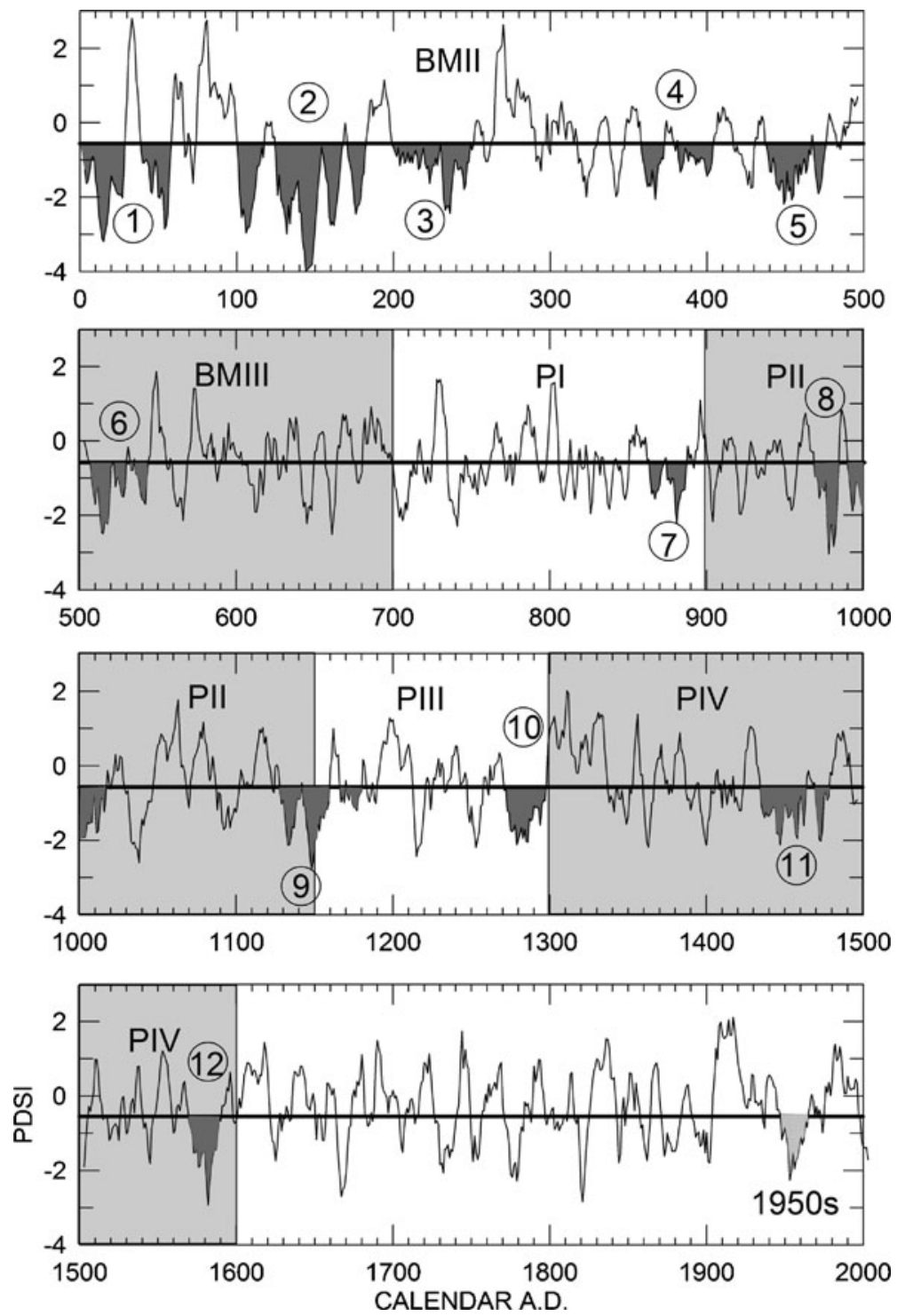

Fig. 22 Tree ring-based reconstruction of the Palmer Drought Severity Index (PDSI) for the past 2,000 years. Droughts numbered 1-12 are megadroughts that occurred during Basketmaker $(B M)$ and Pueblo $(P)$ archaeological stages. A megadrought is defined as a dry period that spans more than 20 years that has annual PDSI values that are less than -1 for at least $60 \%$ of the dry period and that contains at least two $\geq 3$ consecutive-year droughts with PDSI values less than -1 . The 1950 s drought, which strongly impacted the Southwest, is also shown for comparison. The record seen here represents a composite of nine PDSI records centered on Holbrook, Arizona. See Fig. 1 in Benson and Berry (2009) for locations of the PDSI sites

production of maize. Contour maps of these parameters of course do not tell the entire story; that is, they tend to smooth parameter variability that may characterize a particular archaeological region such as Chaco Canyon. For that reason, I will treat the climate, hydrology, and nutrient chemistry of the Chaco Halo, Mesa Verde, Zuni, 
and Pajarito Plateau archaeological regions separately and in some detail in Part 2 of this study.

Acknowledgments The author wishes to thank Dave Meko and Jeffrey Dean at the University of Arizona for access to some of the tree-ring data sets used in this paper. Dwayne Westfall at Colorado State University provided data on corn production for the state of Colorado. This study is based, in part, upon research supported by the National Science Foundation under grant No. DEB-0816400 and by the Arid Regions Climate Project in the National Research Program of the U.S. Geological Survey. This work supports the Village Ecodynamics Project whose objectives include agent-based modeling of the interactions between prehistoric Native Americans who occupied the Four Corners region of the American Southwest, the landscape they occupied, and the climate that impacted the region during the late-thirteenth century. Reviews of an earlier version of this manuscript were ably performed by Richard Smith and Keith Lucey of the U.S. Geological Survey and by Kenneth Peterson of the University of Utah. My appreciation also to three anonymous reviewers whose comments strengthened this study.

\section{References}

Abdul-Jabbar, A. S., Sammin, J. W., Lugg, D. G., Kallsen, C. E., \& Smeal, D. (1983). Water use by alfalfa, maize, and barley as influenced by available soil water. Agricultural Water Management, 6 , 351-363.

Adams, K. R. (2004). Anthropogenic ecology of the North American Southwest. In P. E. Minnis (Ed.), People and plants in ancient western North America (pp. 167-204). Washington: Smithsonian Books.

Adams, D. K., \& Comrie, A. C. (1997). The North American monsoon. Bulletin of the American Meteorology Society, 78, 2197-2213.

Adams, K. R., Muenchrath, D. A., \& Schwindt. (1999). Moisture effects on the morphology of ears, cobs, and kernels on a South-western U.S. maize (Zea Mays L.) cultivar, and implications for the interpretation of archaeological maize. Journal of Archaeological Science, 26, 483-496.

Adams, K. R., Meegan, C. M., Ortman, S. G., Howell, R. E., Werth, L. C., Muenchrath, D. A., et al. (2006). MAIS (Maize of American Indigenous Societies) Southwest: Ear descriptions and traits that distinguish 27 morphologically distinct groups of 123 historic USDA maize (Zea mays L. spp. Mays) accessions and data relevant to archaeological subsistence models. http://spectre.nmsu.edu (projects and results, collaborative MAIS Experiment).

Aleksandrovskii, A. L. (2007). Pyrogenic origin of carbonates: Evidence from pedoarchaeological investigations. Eurasian Soil Science, 40, 471-477.

Allen, R. G., Pruitt, W. O., Raes, D., Smith, M., \& Pereira, L. S. (2005). Estimating evaporation from bares soil and the crop coefficient for the initial period using common soils information. Journal of Irrigation and Drainage Engineering, 131, 14-23.

Allison, F. E. (1955). The enigma of nitrogen balance sheets. Advances in Agronomy, 7, 213-250.

Amos, B., \& Walters, D. T. (2006). Maize root biomass and net rhizodeposited carbon: An analysis of the literature. Soil Science of America Journal, 70, 1489-1503.

Arrhenius, O. (1963). Investigation of soil from old Indian sites. Ethnos, 28, 122-136.

Ayers, R. S. (1977). Quality of water for irrigation. Journal of Irrigation and Drainage Division, 103, $135-154$.

Barber, A. S., \& Olson, R. A. (1968). Fertilizer use on corn, changing patterns in agriculture. In L. B. Nelson \& M. H. McVickar (Eds.), Changing patterns in fertilizer use (pp. 168-188). Madison: Soil Science Society of America.

Beaglehole, E. (1937). Notes on Hopi economic life. Yale University Publication in Anthropology 15, Yale University Press, New Haven.

Bear, F. E., \& Royston, J. R. (1919). Nitrogen losses in urine. Journal of the American Society of Agronomy, 11, 319-326.

Bellorado, B. A. (2007). Breaking down the models: Reconstructing prehistoric subsistence agriculture in the Durango District of Southwestern Colorado. Unpublished M.A. dissertation, Department of Anthropology, Northern Arizona University, Flagstaff.

Belnap, J. (2002). Nitrogen fixation in biological soil crusts from southeast Utah, USA. Biology and Fertility of Soils, 35, 128-135. 
Below, F. E. (2002). Nitrogen metabolism and crop productivity. In M. Pessarlakli (Ed.), Handbook of plant and crop physiology (2nd ed., pp. 385-406). Boca Raton: CRC.

Benoit, G. R., \& Kirkham, D. (1963). The effect of soil surface conditions on evaporation of soil water. Soil Science Society of America Proceedings, 27, 495-498.

Benson, L. V., \& White, J. W. C. (1994). Stable isotopes of oxygen and hydrogen in the Truckee RiverPyramid Lake surface-water system. 3. Sources of water vapor overlying Pyramid Lake. Limnology and Oceanography, 39, 1945-1958.

Benson, L. V., \& Berry, M. S. (2009). Climate change and cultural response in the prehistoric American Southwest. Kiva, 75, 89-119.

Benson, L., Petersen, K., \& Stein, J. (2007). Anasazi (pre-Columbian Native-American) migrations during the middle-12th and late-13th centuries-Were they drought induced? Climatic Change, 83, 187-213.

Benz, B. F. (2001). Archaeological evidence of teosinte domestication from Guila Naquitz, Oaxaca. Proceedings of the National Academy of Sciences, 98, 2104-2106.

Benz, B. F., Cheng, L., Leavitt, S. W., \& Eastoe, C. (2006). El Riego and early maize agricultural evolution. In J. E. Staller, R. H. Tykot, \& B. F. Benz (Eds.), Histories of maize (pp. 73-82). New York: Elsevier.

Berg, B., McClaugherty, C., Virzo de Santo, A., \& Johnson, D. (2001). Humus buildup in boreal forestsEffects of litter fall and its N concentration. Canadian Journal of Forestry Research, 31, 988-998.

Berzok, L. M. (2005). American Indian food. Santa Barbara: Greenwood Publishing Group.

Biswas, T. D., Nielsen, D. R., \& Biggar, J. W. (1966). Redistribution of soil water after infiltration. Water Resources Research, 2, 513-524.

Blackmer, A. M., Pottker, D., Cerrato, M. E., \& Webb, J. (1989). Correlations between soil nitrate concentrations in late spring and corn fields in Iowa. Journal of Production Agriculture, 2, 103-109.

Blackmer, A. M., Voss, R. D., \& Mallarino, A. P. (1997). Nitrogen fertilizer recommendations for Corn in Iowa. Iowa State University Extension Publication Pm-1714. Ames, Iowa.

Blake, M. (2006). Dating the initial spread of Zea Mays. In J. E. Staller, R. H. Tykot, \& B. F. Benz (Eds.), Histories of maize (pp. 55-72). New York: Elsevier.

Boehm, H. P. (1971). Acidic and basic properties of hydroxylated metal oxide surfaces. Discussions of the Faraday Society, 52, 264-275.

Boone, R. D. (1994). Light-fraction soil organic matter: Origin and contribution to net nitrogen mineralization. Soil Biology and Biochemistry, 26, 1459-1468.

Borza, I. (2008). Study regarding the weeds influence on water use efficiency in maize crop from the Crisurilor Plain. Anaele Universitatii din Oradea, Fascicula: Protectia Mediului XIII, pp. 20-25.

Bradfield, M. (1971). The changing pattern of Hopi agriculture. Royal Anthropological Institute Occasional Paper No. 30.

Brady, N. C., \& Weil, R. R. (2008). The nature and properties of soils, 14th ed.. Columbus: Pearson Prentice Hall.

Brandt, C. B. (1995). Traditional agriculture on the Zuni reservation in the recent historic period. In W. Toll (Ed.), Soil, water, biology, and belief in prehistoric and traditional Southwestern agriculture (pp. 291-301). Albuquerque: New Mexico Archaeological Council Special Publication No. 2.

Bremmer, J. M. (1965). Nitrogen availability indexes. In C. A. Black (Ed.), Methods of soil analysis, part 2. Agronomy Monograph 9 (pp. 1324-1345). Madison: Soil Science Society of America.

Breshears, D. D., Cobb, N. S., Rich, P. M., Price, K. P., Allen, C. D., Balice, R. G., et al. (2005). Regional vegetation die-off in response to global-change-type drought. Proceedings of the National Academy of Sciences, 102, 15144-15148.

Brown, D. P., \& Comrie, A. C. (2002). Sub-regional seasonal precipitation linkages to SOI and PDO in the Southwest United States. Atmospheric Science Letters, 3, 94-102.

Brown, W. L., Anderson, E. G., \& Tuchawena, R., Jr. (1952). Observations on three varieties of Hopi maize. American Journal of Botany, 39, 597-609.

Bundy, L. G., \& Meisinger. (1994). Nitrogen availability indices. In R. W. Weaver (Ed.), Methods of soil analysis, part 2. Book Series 5 (pp. 951-984). Madison: Soil Science Society of America.

Byrne, P. F., Terpstra, K. A., Dabbert, T. A., \& Alexander, R. (2003). Estimating pollen-mediated flow in corn under Colorado conditions. Annual Meeting Abstracts of the Soil Science Society of America Annual Meeting, Madison, Wisconsin.

Cattlenetwork (2008). http://www.cattlenetwork.com/Top-10-Countries-With-The-Most-Corn-Produc tion/2008-03-17/Article.aspx?oid=62054.

Cerrato, M. E., \& Blackmer, A. M. (1990). Effects of nitrapyrin on corn yields and recovery of ammonium-N at 18 site-years in Iowa. Journal of Production Agriculture, 3, 513-521. 
Chapin, F. S., III, Matson, P. A., \& Mooney, H. A. (2002). Principles of terrestrial ecosystem ecology. New York: Springer.

Choriki, R. T., Hide, J. C., Krall, S. L., \& Brown, B. L. (1964). Rock and gravel mulch aid in moisture storage. Crops and Soil, 16, 24.

Clarholm, M. (1985). Interactions of bacteria, protozoa and plants leading to mineralization of soil nitrogen. Soil Biology and Biochemistry, 17, 181-187.

Clark, S. P. (1928). Lessons from Southwestern Indian agriculture. College of Agriculture, Experimental Station Bulletin 125. University of Arizona, Tucson.

Clay, D. E., Clapp, C. E., Reese, C., Liu, Z., Carlson, C. G., Woodward, H., et al. (2007). Carbon-13 fractionation of relic soil organic carbon during mineralization effects calculated half-lives. Soil Science Society of America Journal, 71, 1003-1009.

Coltrain, J. B., Janetski, J. C., \& Carlyle, S. W. (2006). The stable- and radio-isotope chemistry of Eastern Basketmaker and Pueblo Groups in the Four Corners region of the American Southwest: Implications for Anasazi diets, origins, and abandonments in Southwestern Colorado. In J. E. Staller, R. H. Tykot, \& B. F. Benz (Eds.), Histories of maize (pp. 275-287). New York: Academic Press.

Coltrain, J. B., Janetski, J. C., \& Carlyle, S. W. (2007). The stable- and radio-isotope chemistry of Western Basketmaker burials: Implications for early Puebloan diets and origins. American Antiquity, 72, 301321.

Cook, E. R., Woodhouse, C. A., Eakin, C. M., Meko, D. M., \& Stahle, D. W. (2004). Long-term aridity changes in the Western United States. Science, 306, 1015-1018.

Corral, J. A. R., Puga, N. D., González, J. J. S., Parra, J. R., Eguiarte, D. R. G., Holland, J. B., et al. (2008). Climatic adaptation and ecological descriptors of 42 Mexican maize races. Crop Science, 48 , 1502-1512.

Cushing, F. H. (1920). Zuni breadstuff. Indian notes and monographs, volume 2. New York: Museum of the American Indian, Heye Foundation.

D'arrigo, R., Villalba, R., \& Wiles, G. (2001). Tree-ring estimates of pacific decadal climate variability. Climate Dynamics, 18, 219-224.

Dahnke, W. C., \& Johnson, G. V. (1990). Testing soils for available nitrogen. In R. L. Westerman (Ed.), Soil testing and plant analysis (3rd ed., pp. 97-114). Madison: Soil Science Society of America.

DeLoughery, R., \& Wortmann, C. (2005). Calculating the value of manure for crop production. University of Nebraska-Lincoln Extension, Institute of Agriculture and Natural Resources NebGuide G9330.

Derby, N. E., Steelea, D. D., Terpstraa, J., Knighton, R. E., \& Caseya, F. X. M. (2005). Interactions of nitrogen, weather, soil, and irrigation on corn yield. Agronomy Journal, 97, 1342-1351.

Dietz, T., Abdirizak, N. N., Roba, A. W., \& Zaal, F. (2001). Pastor commercialization: On caloric terms of trade and related issues. In M. A. M. Salih, T. Dietz, \& A. G. M. Ahmed (Eds.), African pastorialism: Conflict, institutions, and government (pp. 194-234). London: Pluto.

DiMarco, O. N., Aello, M. S., \& Chicatun, A. (2007). Effect of irrigation on corn plant dry matter yield, morphological components and ruminal degradability of leaves and stems. Journal of Animal and Veterinary Advances, 6, 8-11.

Doerge, T. A. (1985). A summary of soil test information for Arizona's surface agricultural soils. University of Arizona Cooperative Extension Service Report No. 8613.

Dominguez, S., \& Kolm, K. (2005). Beyond water harvesting: A soil hydrology perspective on traditional Southwestern agricultural technology. American Antiquity, 70, 732-765.

Dwyer, L. M., Ma, B. L., Stewart, D. W., Hayhoe, H. N., Bachin, D., Culley, J. L. B., et al. (1996). Root mass distribution under conventional and conservation tillage. Canadian Journal of Soil Science, 76, 23-28.

Elmore, R., \& Abendroth, L. (2008). Seeding rates in relation to maximum yield and seed cost. Iowa State University Agronomy Extension, Integrated Crop Management Extension Newsletter. http://www. agronext.iastate.edu/corn/production/management/planting/yield.html.

Enfield, D. B., Mestas-Nunez, A. M., \& Trimble, P. J. (2001). The Atlantic Multidecadal Oscillation and its relation to rainfall and river flows in the Continental U.S. Geophysical Research Letters, 28, 20772080.

Esrey, S. A., Andersson, I, Hillers, A., \& Sawyer, R. (2000). Closing the loop, ecological sanitation for food security. Swedish International Development Cooperation Agency, Publications on Water Resources No. 18.

Ethanol Statistics (2008). cta.ornl.gov/bedb/biofueils/ethanol/Ethanol_Production_Statistics.xls.

Euler, R. C. (1954). Environmental adaptation at Sia Pueblo. Human Organization, 12, 27-30.

Evans, R. D., \& Ehleringer, J. R. (1993). A break in the nitrogen cycle in arid lands? Evidence from $\delta^{15} \mathrm{~N}$ of soils. Oecologia, 94, 314-317. 
Fang, C., Smith, P., Moncrieff, J. B., \& Smith, J. U. (2005). Similar response of labile and resistant soil organic matter pools to changes in temperature. Nature, 433, 57-59.

Farnham, D. (2001). Corn planting guide. Iowa State University Extension Publication PM 1885.

Fehrenbacher, J. B., \& Rust, R. H. (1956). Corn root penetration in soils derived from various textures of Wisconsin-age glacial till. Soil Science, 82, 369-378.

Ferguson, T. J., \& Hart, E. R. (1985). A Zuni Atlas. Norman: University of Oklahoma Press.

Follett, R. F., Paul, E. A., Leavitt, S. W., Halvorson, A. D., Lyon, D., \& Peterson, G. A. (1997). Carbon isotope ratios of Great Plains soils and in wheat-fallow systems. Soil Science Society of American Journal, 61, 1068-1077.

Ford, R. I. (1985). Zuni land use and damage to Trust land, Plaintiff's Exhibit 7000. Expert testimony submitted to the United States Claims Court as evidence in the case Zuni Indian Tribe v. United States, Docket 327-81L, August 15, 1985.

Ford, R. I. (1987). Dating early maize in the eastern United States. Paper presented at the Annual Meeting of the American Association for the Advancement of Science, February 14-18, 1987, Chicago.

Forde, C. D. (1931). Hopi agriculture and land ownership. Journal of the Royal Anthropological Institute, $41,357-405$.

Foth, H. D., \& Ellis, B. G. (1988). Soil fertility. New York: Wiley.

Fowler, D. B., \& Brydon, J. (1989). No-till winter wheat production on the Canadian prairies: Placement of urea and ammonium nitrate fertilizers. Agronomy Journal, 81, 518-524.

Fox, R. H., Roth, G. W., Iversen, K. V., \& Piekielek, W. P. (1989). Soil and tissue test compared for predicting soil nitrogen availability to corn. Agronomy Journal, 81, 971-974.

Fye, J. K., Stahle, D. W., \& Cook, E. R. (2003). Paleoclimatic analogs to twentieth-century moisture regimes across the United States. Bulletin of the American Meteorological Society, 84, 901-909.

Gallais, A., \& Coque, M. (2005). Genetic variation and selection for nitrogen use efficiency in maize: A synthesis. Maydica, 50, 531-537.

Gardner, F. P., Pearce, R. B., \& Mitchell, R. L. (1985). Physiology of crop plants. Ames: Iowa State University Press.

Gauthier, R., \& Herhahn, C. (2005). Why would anyone want to farm here? In R. P. Powers (Ed.), The peopling of Bandelier (pp. 27-34). Santa Fe: School of American Research Press.

Gray, S. T., Graumlich, L. J., Betancourt, J. L., \& Pedersen, G. T. (2004). A tree-ring based reconstruction of the Atlantic Multidecadal Oscillation since A.D. 1567. Geophysical Research Letters, 31, L12205.

Hack, J. T. (1942). The changing physical environment of the Hopi Indians of Arizona. Papers of the Peabody Museum 35. Cambridge: Harvard University Press.

Hallauer, A. R., \& Troyer, A. F. (1972). Prolific corn hybrids and minimizing risk of stress. In D. Wilkinson (Ed.), Proceedings of the 27th Annual Corn and Sorghum Research Conference (pp. 140158). Washington: American Seed Trade Association.

Harmsen, G. W., \& Van Schreven, D. A. (1955). Mineralization of organic nitrogen in soil. Advances in Agronomy, 7, 299-398.

Harrison, K. G., Broecker, W. S., \& Bonani. (1993). The effect of changing land use on soil radiocarbon. Science, 262, 725-726.

Hay, R. E., Earley, E. B., \& DeTurk, E. E. (1953). Concentration and translocation of nitrogen compounds in the corn plant (Zea Mays) during grain development. Plant Physiology, 28, 606-621.

Haynes, R. J., Martin, R. J., \& Goh, K. M. (1993). Nitrogen fixation, accumulation of soil nitrogen and nitrogen balance for some field-grown legume crops. Field Crops Research, 35, 85-92.

Hergert, G. W. (1987). Status of residual nitrate-nitrogen soil tests in the United States. In: J. R. Brown (Ed.), Soil testing: Sampling, correlation, calibration, and interpretation (pp. 73-88). Madison, Wisconsin: American Society of Agronomy Special Publication 21, Soil Science Society of America.

Herrmann, A. (2003). Predicting nitrogen mineralization from soil organic matter-A chimera? Unpublished PhD dissertation, Swedish University of Agricultural Sciences, Uppsala.

Hesterman, O. B., Russelle, M. P., Sheaffer, C. C., \& Heichel, G. H. (1987). Nitrogen utilization from fertilizer and legume residues in legume-corn rotations. Agronomy Journal, 79, 726-731.

Hillel, D. (1971). Soil and water: Physical principles and processes. New York: Academic.

Hodge, F. W. (1946). Spanish explorers in the southern United States, 1528-1543. New York: Barnes and Noble.

Hoeft, R. G., \& Peck, T. R. (2002). Soil testing and fertility. In R. G. Hoeft \& E. Nafziger (Eds.), The Illinois agronomy handbook (pp. 91-131). Urbana-Champaign: University of Illinois Extension.

Homaee, M., Feddes, R. A., \& Dirksen, C. (2002). A macroscopic water extraction model for nonuniform transient salinity and water stress. Soil Science Society of American Journal, 66, 1764-1772. 
Homburg, J. A. (2000). Anthropogenic influences on American Indian agricultural soils of the Southwestern United States. Unpublished PhD dissertation, Department of Agronomy, Iowa State University, Ames.

Homburg, J. A., Sandor, J. A., \& Norton, J. B. (2005). Anthropogenic influences on Zuni agricultural soils. Geoarchaeology, 20, 661-693.

Hooker, T. D., \& Stark, J. M. (2008). Soil C and N cycling in three semiarid vegetation types: Response to an in situ pulse of plant debris. Soil Biology \& Biochemistry, 40, 2678-2685.

Hsieh, Y. P. (1993). Radiocarbon signature of turnover rates in active soil organic pools. Soil Science Society of America Journal, 57, 1020-1022.

Huckell, L. W. (2006). Ancient maize in the American Southwest: What does it look like and what can it tell us? In J. E. Staller, R. H. Tykot, \& B. F. Benz (Eds.), Histories of maize (pp. 97-108). New York: Elsevier.

Huntrieser, H., Schlager, H., Feigl, C., \& Höller, H. (1998). Transport and production of $\mathrm{NO}_{x}$ in electrified thunderstorms: survey of previous studies and new observations at midlatitudes. Journal of Geophysical Research, 103, 28247-28264.

Jaeger, C. H., Monson, R. K., Fisk, M. C., \& Schmidt, S. K. (1999). Seasonal partitioning of nitrogen and soil microorganisms in an alpine ecosystem. Ecology, 80, 1883-1891.

Jaenicke-Despres, V. R., \& Smith, B. D. (2006). Ancient DNA and the integration of archaeological and genetic approaches to the study of maize domestication. In J. E. Staller, R. H. Tykot, \& B. F. Benz (Eds.), Histories of maize (pp. 83-95). New York: Elsevier.

Jalota, S. K., \& Prihar, S. S. (1986). Effects of atmospheric evaporativity, soil type, and redistribution time on evaporation from bare soil. Australian Journal of Soil Research, 24, 357-366.

Jarvis, S. C., Stockdale, E. A., Shepherd, M. A., \& Powlson, D. S. (1996). Nitrogen mineralization in temperate agricultural soils: Processes and measurement. Advances in Agronomy, 57, 187-235.

Jastrow, J. D., \& Miller, R. M. (1998). Soil aggregate stabilization and carbon sequestration: Feedbacks through organo-mineral associations. In R. Lal, J. M. Kimball, R. F. Follett, \& B. A. Stewart (Eds.), Soil processes and the carbon cycle (pp. 207-223). Boca Raton: CRC.

Jastrow, J. D., Amonette, J. E., \& Baily, V. L. (2007). Mechanisms controlling soil carbon turnover and their potential application for enhancing carbon sequestration. Climatic Change, 80, 5-23.

Jenkins, M. T. (1941). Influence of climate and weather on growth of corn. In G. Hambidge (Ed.), Climate and man, Yearbook of Agriculture, 1941 (pp. 308-341). Washington: U.S. Department of Agriculture.

Jenkinson, D. S. (1990). The turnover of organic carbon and nitrogen in soil. Philosophical Transactions of the Royal Society of London B, 329, 361-368.

Jenkinson, D. S., \& Rayner, J. H. (1977). The turnover of soil organic matter in some of the Rothamsted classical experiments. Soil Science, 123, 298-305.

Johnson, G. A., Hoverstad, T. R., \& Greenwald, R. E. (1998). Integrated weed management using narrow corn spacing, herbicides and cultivation. Agronomy Journal, 90, 40-46.

Kerr, R. A. (2000). A North Atlantic climate pacemaker for the centuries. Science, 288, 1984-1986.

Lang, C. H., \& Riley, C. L. (1966). The Southwestern journals of Adolph F. Bandelier, 1880-1882. Albuquerque: University of New Mexico Press.

Latshaw, J. W., \& Miller, E. C. (1924). Elemental composition of the corn plant. Journal of Agricultural Research, 27, 845-861.

Leavitt, S. W., Follett, R. F., \& Paul, E. A. (1996). Estimation of slow- and fast-cycling soil organic pools from $6 \mathrm{~N}$ HCL hydrolysis. Radiocarbon, 38, 231-239.

Leirós, M. C., Trasar-Cepeda, C., Seoane, S., \& Gil-Sotres. (1999). Dependence of mineralization of soil organic matter on temperature and moisture. Soil Biology and Biochemistry, 31, 327-335.

Leonard, W. H., Brandon, J. F., \& Curtis, J. J. (1940). Corn production in Colorado. Fort Collins: Colorado Experiment Station Bulletin 463.

Lerner, B. L. (2000). Wood ash in the garden. http://www.hort.purdue.edu/ext/woodash.html.

Li, J. (2009). Production, breeding and process of maize in China. In J. L. Bennetzen \& S. C. Hake (Eds.), Handbook of maize: Its biology (pp. 563-576). New York: Springer.

Lieth, H. (1975). Modeling the primary productivity of the world. In H. Lieth \& R. H. Whittaker (Eds.), Primary productivity of the biosphere, vol. 14 (pp. 237-263). New York: Springer.

Lightfoot, D. R. (1990). The prehistoric pebble-mulched fields of the Galisteo Anasazi: Agricultural innovation and adaptation to environment. Unpublished $\mathrm{PhD}$ dissertation, University of Colorado, Boulder.

Lightfoot, D. R., \& Eddy, F. W. (1994). The agricultural utility of lithic-mulch gardens: Past and present. GeoJournal, 34(4), 425-437. 
Lindemann, W. C., \& Glover, C. R. (2003). Nitrogen fixation by legumes. New Mexico Cooperative Extension Service Guide A-129.

Lindquist, J. L., Arkebauer, T. J., Walters, D. T., Cassman, K. G., \& Dobermann, A. (2005). Maize radiation use efficiency under optimal growth conditions. Agronomy Journal, 97, 72-78.

Lindsay, W. L. (1979). Chemical equilibria in soils. New Jersey: Blackburn.

Linsley, B. K., Wellington, G. M., \& Schrag, D. P. (2000). Decadal sea surface temperature variability in the subtropical South Pacific from 1726 to 1997 A.D.. Science, 290, 1145-1148.

Lloyd, J., \& Taylor. (1994). On the temperature dependence of soil respiration. Functional Ecology, 8, $315-323$.

Lorenz, K., Lal, R., \& Shipitalo, M. J. (2006). Stabilization of organic carbon in chemically separated pools in no-till and meadow soils in Northern Appalachia. Geoderma, 137, 205-211.

Ludwig, J. A. (1987). Primary productivity in arid lands: Myths and realities. Journal of Arid Environments, 13, 1-7.

MacDonald, G. M., \& Case, R. A. (2005). Variations in the Pacific Decadal Oscillation over the past millennium. Geophysical Research Letters, 32(L08703), 4.

MacDowell, M. (1919). Report on the Zuni Reservation, New Mexico. Manuscript on file with the Zuni Archaeology Program, Zuni, New Mexico.

Machinet, G. E., Bertrand, I., Chabbert, B., Watteau, F., Villemin, G., \& Recous, S. (2009). Soil biodegradation of maize root residues: Interaction between chemical characteristics and the presence of colonizing micro-organisms. Soil Biology \& Biochemistry, 41, 1253-1261.

Magdoff, F. D., Ross, D., \& Amadon, J. (1984). A soil test for nitrogen availability to corn. Soil Science Society of America Journal, 48, 1301-1304.

Mantua, N. J., Hare, S. R., Zhang, Y., Wallace, J. M., \& Francis, R. C. (1997). A Pacific interdecadal climate oscillation with impacts on salmon production. Bulletin of the American Meteorological Society, 78, 1069-1079.

Martel, Y. A., \& Paul, E. A. (1974). The use of radiocarbon dating of organic matter in the study of soil genesis. Soil Science Society of America Proceedings, 38, 501-506.

Martin, J. P., \& Haider, K. (1986). Influence of mineral colloids on turnover rates of soil organic carbon. In P. M. Huang \& M. Schnitzer (Eds.), Interactions of soil minerals with natural organics and microbes (pp. 283-304). Madison: Soil Science Society of America Special Publication 17.

Masse, W. B. (1980). Excavations at Gu Achi: A reappraisal of Hohokam settlement and subsistence in the Arizona Papagueria. Publications in Anthropology No. 12, Western Archaeological Center, Tucson.

Matsuoka, Y., Vigouroux, Y., Goodman, M. M., Sanchez, J., Buckler, E., \& Doebly, J. (2002). A single domestication for maize shown by multilocus microsatellite genotyping. Proceedings of the National Academy of Sciences, 99, 6080-6084.

Mattson, S., \& Pugh, A. J. (1934). The electrokinetics of hydrous oxides and their anionic exchange. Soil Science, 38, 299-313.

Matula, S. (2003). The influence of tillage treatments on water infiltration into soil profile. Plant and Soil Environment, 49, 298-306.

McCabe, G. J., Palecki, M. A., \& Betancourt, J. L. (2004). Pacific and Atlantic Ocean influences on multidecadal drought frequency in the United States. Proceedings of the National Academy of Sciences, 101, 4136-4141.

McDonald, J. (1956). Variability of precipitation in an arid region: A survey of characteristics for Arizona. Technical report on the meteorology and climatology of Arid Regions 1. The Institute of Atmospheric Physics, University of Arizona, Tucson.

Mengü, G. P., \& Özgürel, M. (2008). An evaluation of water-yield relations in Maize (Zea mays L.) in Turkey. Pakistan Journal of Biological Sciences, 11, 517-524.

Miller, E. L., Meeuwig, R. O., \& Budy, J. D. (1981). Biomass of singleleaf pinyon and Utah juniper. U.S. Department of Agriculture, Forest Service, Intermountain Forest and Range Experimental Station Research Paper INT-273.

Monteith, J. L. (1977). Climate and the efficiency of crop production in Britain. Philosophical Transactions of the Royal Society Series B, 281, 277-294.

Morgan, P. (2007). Toilets that make compost: Low-cost sanitary toilets that produce valuable compost for crops in an African context. Stockholm Environment Institute EcoSanRes Programme, Stockholm, Sweden. http://www.ecosanres.org/pdffiles/ToiletsThatMakeCompost.pdf.

Morote, C. G. B., Vidor, C., \& Mendes, N. G. (1990). Alterações na temperatura do solo pela cobertura morta e irrigação. Revista Brasileirade Ciência do Solo, 18, 81-84.

Mortvedt, J. J., Westfall, D. G., \& Croissant, R. L. (2007). Fertilizing corn. Colorado State University Extension Publication No. 0.538, Fort Collins, Colorado. 
Muchow, R. C., Sinclair, T. R., \& Bennett, J. M. (1990). Temperature and solar radiation effects on potential maize yield across locations. Agronomy Journal, 82, 338-343.

Muenchrath, D. A., \& Salvador, R. J. (1995). Maize productivity and agroecology: Effects of environment and agricultural practices on the biology of maize. In H. W. Toll (Ed.), Soil, water, biology, and belief in prehistoric and traditional southwestern agriculture (pp. 303-333). Albuquerque: New Mexico Archaeological Council Special Publication No. 2.

Muenchrath, D. A., Kuratomi, M., Sandor, J. A., \& Homburg, J. A. (2002). Observational study of maize production in semiarid New Mexico. Journal of Ethnobiology, 22, 1-33.

Müller, A. G. (2001). Modelagem da matéria seca e do rendimento de grãos de hilho em relacão à disponibilidade hidrica. Porto Alegre: Tese Doutorado em Fitotecnia.

Myrold, D. D. (1998). Microbial nitrogen transformations. In D. M. Sylvia, J. J. Fuhrmann, P. G. Hartel, \& D. A. Zuberer (Eds.), Principles and applications of soil microbiology (pp. 259-294). Upper Saddle River: Prentice Hall.

Nabhan, G. P. (1984). Soil fertility renewal and water harvesting in Sonoran Desert agriculture: The Papago example. Arid Lands Newsletter, 20, 21-28.

Nafziger, E. D. (2002). Corn. In R. Hoeft \& E. D. Nafziger (Eds.), Illinois agronomy handbook. University of Illinois Department of Crop Sciences (pp. 22-34). Urbana: University of Illinois.

Nakamoto, T. (1989). Development of rooting zone in corn plant. Japanese Journal of Crop Science, 58, $648-652$.

Nesbitt, S. W., Zhang, R., \& Orville, R. E. (2000). Seasonal and global $\mathrm{NO}_{x}$ production by lightning estimated from the optical transient detector (OTD). Tellus, 52B, 1206-1215.

Ni, F., Cavazos, T., Hughes, M. K., Comrie, A. C., \& Funkhouser, G. (2002). Cool-season precipitation in the southwestern USA since AD 1000: Comparison of linear and nonlinear techniques for reconstruction. International Journal of Climatology, 22, 1645-1662.

Norman, J. M., \& Arkebauer, T. J. (1991). Predicting canopy photosynthesis and light use efficiency from leaf characteristics. In K. J. Boote \& R. S. Loomis (Eds.), Modeling crop photosynthesis-From biochemistry to canopy (pp. 75-94). Madison: Crop Science Society of America Special Publication 19.

Norton, J. M., \& Firestone, M. K. (1991). Metabolic status of bacteria and fungi in the rhizosphere of ponderosa pine seedlings. Applied and Environmental Microbiology, 57, 1161-1167.

Norton, E. R., \& Silvertooth, J. C. (1998). Field determination of permanent wilting point. In J. C. Silvertooth (Ed.), Cotton, a College of Agriculture Report Series P-112 (pp. 230-237). Tucson: University of Arizona College of Agriculture and Life Sciences, Cooperative Extension Publication No. AZ1006.

Norton, J. B., Sandor, J. A., \& White, C. S. (2003). Hillslope soils and organic matter dynamics within a Native American agroecosystems on the Colorado Plateau. Soil Science Society of America Journal, 67, 225-234.

Norton, J. B., Sandor, J. A., \& White, C. S. (2007a). Runoff and sediments from Hillslope soils within a Native American agroecosystem. Soil Science Society of America Journal, 71, 476-483.

Norton, J. B., Sandor, J. A., White, C. S., \& Laahty, V. (2007b). Organic matter transformations through arroyos and alluvial fan soils within a Native American agroecosystem. Soil Science Society of America Journal, 71, 829-835.

Noy-Meir, I. (1973). Desert ecosystems: Environment and producers. Annual Review of Ecological Systems, 4, 25-52.

Odend'hal, S. (1993). Intermediary agricultural energetics: A case study of solar energy linkage with Chinese working cattle. Agriculture, Ecosystems, and Environment, 43, 217-233.

Oregon Climate Service (2009). http://www.ocs.orst.edu/pub/maps/Precipitation/Total/.

Parnes, R. (1990). Fertile soil, a grower's guide to organic and inorganic fertilizers. Davis: AgAccess.

Parton, W. J., Stewart, J. W. B., \& Cole, C. V. (1988). Dynamics of C, N, P, and S in grassland soils: A model. Biogeochemistry, 5, 109-131.

Parton, W. J., Scurolci, M. D., Ojima, D. S., Gilmanor, T. G., Scholos, R. J., Schimel, D. S., et al. (1993). Observations and modeling of biomass and soil organic matter dynamics for the grassland biome world wide. Global Biogeochemical Cycles, 7, 785-809.

Paul, E. A., Horwath, W. R., Harris, D., Follett, R., Leavitt, S., Kimball, B. A., et al. (1995). Establishing the pool sizes and fluxes of $\mathrm{CO}_{2}$ emissions from soil organic matter turnover. In R. J. Lal, J. Kimble, E. Levine, \& B. A. Stewart (Eds.), Soils and global change (pp. 297-308). Boca Raton: Lewis.

Paul, E. A., Follett, R. F., Leavitt, S. W., Halvorson, A., Peterson, G. A., \& Lyons, D. J. (1997). Radiocarbon dating for determination of soil organic matter pool sizes and dynamics. Soil Science Society of America Journal, 61, 1058-1067.

Paul, E. A., Collins, H. P., \& Leavitt, S. W. (2001). Dynamics of resistant soil carbon of Midwestern agricultural soils measured by naturally occurring ${ }^{14} \mathrm{C}$ abundance. Geoderma, 104, 239-256. 
Paul, E. A., Morris, S. J., Conant, R. T., \& Plante, A. F. (2006). Does the acid hydrolysis-incubation method measure meaningful soil organic carbon pools? Soil Science Society of America Journal, 70, 1023-1035.

Petersen, K. L. (1986), Climate reconstruction for the Dolores Project area. In D. A. Breternitz, C. K. Robinson, \& G. T. Gross (Compilers), Dolores Archaeological Program: Final Synthetic Report (pp. 311-331). Denver: United States Department of the Interior, Bureau of Reclamation Engineering and Research Center.

Pierzynski, G. M. (2000). Methods of phosphorous analysis for soils, sediments, residuals, and waters. Manhattan, Kansas: Southern Cooperative Series Bulletin No. 396.

Piperno, D. R., \& Flannery, K. V. (2001). The earliest archaeological maize (Zea mays L.) from highland Mexico: New accelerator mass spectrometry dates and their implications. Proceedings of the National Academy of Sciences, 98, 2101-2103.

Pordesimo, L. O., Edens, W. C., \& Sokhansanj, S. (2004). Distribution of aboveground biomass in corn stover. Biomass and Bioenergy, 26, 337-343.

Porter, E., Tonnessen, K., Sherwell, J., \& Grant, R. (2000). Nitrogen in the nation's rain. NADP Brochure 2000-01C (revised). http://nadp.sws.uiuc.edu/lib/brochures/nitrogen.pdf.

Post, W. M., \& Kwon, K. C. (2000). Soil carbon sequestration and land-use change: Processes and potential. Global Change Biology, 6, 317-327.

Prevost, D. J., Ahrens, R. J., \& Kriz, D. M. (1984). Traditional Hopi agricultural methods. Journal of Soil and Water Conservation, 39, 170-171.

Price, C., Penner, J., \& Prather, M. (1997). $\mathrm{NO}_{x}$ from lightning. 1. Global distribution based on lightning physics. Journal of Geophysical Research, 102, 5929-5941.

Qin, R., Stamp, P., \& Richner, W. (2006). Impact of tillage on maize rooting in a Cambisol and Luvisol in Switzerland. Soil \& Tillage Research, 85, 50-61.

Raison, R. J., Khanna, P. K., \& Woods, P. V. (1985). Mechanisms of element transfer to the atmosphere during vegetation fires. Canadian Journal of Forest Research, 15, 132-140.

Rakshit, A., \& Bhadoria, P. (2008). Measurement of arbuscular mycorrhizal hyphal length and prediction of P influx by mechanistic model. World Journal of Agricultural Sciences, 4, 23-27.

Ranney, R. W. (1969). An organic carbon-organic matter conversion equation for Pennsylvania surface soils. Soil Science Society of America Journal, 33, 809-811.

Rao, D. L. N., \& Batra, L. (1983). Ammonia volatilization from applied nitrogen in alkali soils. Plant Soil, 70, 219-228.

Rasmussen, P. E., Douglas, C. L., Jr., Collins, H. P., \& Albrecht, S. L. (1998). Long-term cropping system effects on mineralizable nitrogen in soil. Soils Biology and Biochemistry, 30, 1829-1837.

Rauch, W., Brockmann, D., Peters, I., Larsen, T. A., \& Gujer, W. (2003). Combining urine separation with waste design: An analysis using a stochastic model for urine production. Water Research, 37, 681-689.

Reddy, K. S., Mills, H. A., \& Jones, J. B., Jr. (1991). Corn responses to post-tasseling nitrogen deprivation and to various ammonium/nitrate ratios. Agronomy Journal, 83, 201-203.

Risse, M. (2002). Best management practices for wood ash as agricultural soil amendment. http://hubcap. clemson.edu/ blpprt/bestwoodash.html.

Rose, D. A. (1968). Water movement in porous materials III: Evaporation of water from soil. British Journal of Applied Physics, 1, 1779-1791.

Runge, E. C. A. (1968). Effects of rainfall and temperature interactions during the growing season on corn yield. Agronomy Journal, 60, 503-507.

Sala, O. E., Parton, W. J., Joyce, L. A., \& Lauenroth, W. K. (1988). Primary production of the central grassland region of the United States. Ecology, 69, 40-45.

Salton, J. C., \& Mielniczuk, J. (1995). Relações entre sistemas de preparo, temperatura e umidade de um podzólico vermelho-escuro de Eldorado do Sul (RS). Revista Brasileira de Ciência do Solo, 19, 313-2319.

Salvador, R. J. (1997). The maize page. http://www.biologie.uni-hamburg.de/b-online/library/maize/www. ag.iastate.edu/departments/agronomy/.maizearticle.html.

Sandor, J. A. (1995). Searching soil for clues about Southwest prehistoric agriculture. In H. W. Toll (Ed.), Soil, water, biology, and belief in prehistoric and traditional Southwestern Agriculture (pp. 119-137). Albuquerque: New Mexico Archaeological Council Special Publication No. 2.

Sandor, J. A., \& Gersper, P. L. (1988). Evaluation of soil fertility in some prehistoric agricultural terraces in New Mexico. Agronomy Journal, 80, 846-850. 
Sandor, J. A., Norton, J. B., Homburg, J. A., Muenchrath, D. A., White, C. S., Williams, S. E., et al. (2007). Biogeochemical studies of a Native American runoff agroecosystem. Geoarchaeology, 22, 359-386.

Sawyer, J. E., \& Mallarino, A. P. (2007). Nutrient removal when harvesting corn stover. Iowa State University Extension Integrated Crop Management Newsletter IC-498, pp. 251-253. Ames: Iowa State Agronomy Extension.

Sawyer, J. E., Mallarino, A. P., Killorn, R., \& Barnhart, S. K. (2008). A general guide for crop nutrient and limestone recommendations in Iowa. Iowa State University Extension PM 1688. http://www. extension.iastate.edu/Publications/PM1688.pdf.

Schroeder, J. J., Neeteson, J. J., Oenema, O., \& Stuik, P. C. (2000). Does the crop or the soil indicate how to save nitrogen in maize production? Reviewing the state of the art. Field Crops Research, 66, 151-164.

Schubert, S. D., Suarez, M. J., Pegion, P. J., Koster, R. D., \& Bacmeister, J. T. (2004). On the cause of the 1930s dust bowl. Science, 303, 1855-1859.

Shaw, R. H. (1988). Climate requirement. In G. F. Sprague \& J. W. Dudley (Eds.), Corn and corn improvement, 3rd ed. (pp. 609-638). Madison: American Society of Agronomy.

Shinners, K. J., \& Binversie, B. N. (2007). Fractional yield and moisture of corn stover biomass produced in the northern US Corn Belt. Biomass \& Energy, 31, 576-584.

Silveira, M. L., Comerford, N. B., Reddy, K. R., Cooper, W. T., \& El-Rifai, H. (2008). Characterization of soil organic carbon pools by acid hydrolysis. Geoderma, 144, 405-414.

Sinclair, T. R., \& Muchow, R. C. (1999). Radiation use efficiency. Advances in Agronomy, 65, 215-265.

Smith, R. (2004). Nitrogen dynamics in woody plant ecosystems: Almond orchards, winegrape vineyards, and pinyon-juniper woodlands. Unpublished $\mathrm{PhD}$ dissertation, University of California, Davis.

Soleri, D., \& Smith, S. E. (1995). Morphological and phonological comparisons of two Hopi maize varieties conserved in situ and ex situ. Economic Botany, 49, 56-77.

Sommer, S. G., Olesen, J. E., \& Christensen, B. T. (1991). Effects of temperature, wind speed and air humidity on ammonia volatilization from surface applied cattle slurry. Journal of Agricultural Science, 117, 91-100.

Soudi, B., Sbai, A., \& Chiang, C. N. (1990). Nitrogen mineralization in semiarid soils of Morocco: Rate constant variation with depth. Soil Science Society of America Journal, 54, 756-761.

Stephen, A. M. (1936). Hopi journal of Alexander Stephen. In E. C. Parsons (Ed.), Columbia University contribution to anthropology series 23. New York: Columbia University Press.

Stevenson, M. C. (1915). Ethnobotany of the Zuni Indians: Annual report (1908-1909). Bureau of American Ethnology 30 (pp. 35-102). Washington: Smithsonian Institution.

Stewart, G. R. (1940). Conservation in Pueblo agriculture. Scientific Monthly, 56(201-220), 329-340.

Stuart, J. W. (1990). Maize use by rural Mesoamerican households. Human Organization, 49, 135-139.

Stott, E., Kassin, G., Jarrell, W. M., Martin, J. P., \& Haider, K. (1983). Stabilization and incorporation into biomass of specific plant carbons during biodegradation in soil. Plant and Soil, 70, 15-26.

Swift, M. J., Heal, O. W., \& Anderson, J. M. (1979). Decomposition in terrestrial ecosystems. Studies in ecology, vol. 5. Oxford: Blackwell Scientific.

Ta, C. T., \& Weiland, R. T. (1992). Nitrogen partitioning in maize during ear development. Crop Science, $32,443-451$.

Taiz, L., \& Zeiger, E. (2002). Plant physiology. Sunderland: Sinauer.

Thomison, P. (2009). Managing "pollen drift" to minimize contamination on non-GMO corn. Ohio State University Extension Fact Sheet AGF-153-04. Columbus: Ohio State.

Thompson, L. M. (1969). Weather and technology in the production of corn in the U.S. Corn Belt. Agronomy Journal, 61, 453-456.

Tie, X., Zhang, R., Brasseur, G., \& Lie, W. (2002). Global $\mathrm{NO}_{x}$ production by lightning. Journal of Atmospheric Chemistry, 43, 61-74.

Timmons, D. R., \& Cruse, R. M. (1990). Effect of fertilization method and tillage on nitrogen-15 recovery by corn. Agronomy Journal, 82, 777-784.

Tisdale, S., Nelson, W. L., \& Beaton, J. D. (1985). Soil fertility and fertilizers, 4th ed.. New York: Macmillan.

Todd, R. W., Klocke, N. L., Hergert, G. W., \& Parkhurst, A. M. (1991). Evaporation from soil influenced by crop shading, crop residue, and wetting regime. Transactions of the American Society of Agricultural and Biological Engineers, 34, 461-466.

Underhill, R. M. (1946). Work a day life of the Pueblos. Indian life and customs 4. Phoenix: U.S. Office of Indian Affairs, Phoenix Indian School. 
U.S. Department of Agriculture (2009). Soils data. http://soils.usda.gov/.

U.S. Patent Application 20040126460 (2004). Nutritional mineral supplements from plant ash. http:// www.freepatentsonline.com/y2004/0126460.html.

Van Epps, G. A., Barker, J. R., \& McKell, C. M. (1982). Energy biomass from large rangeland shrubs of the Intermountain United States. Journal of Range Management, 35, 22-25.

Vierra, B. J., \& Ford, R. I. (2006). Early maize agriculture in the northern Rio Grande Valley, New Mexico. In J. E. Staller, R. H. Tykot, \& B. F. Benz (Eds.), Histories of maize (pp. 497-510). New York: Elsevier.

Vinneras, B. (2002). Possibilities for sustainable nutrient recycling by faecal separation combined with urine diversion. Agraria 353, Acta Universitatis Agriculturae Sueciae, Uppsala: Swedish University of Agricultural Sciences.

Waksman, S. A., \& Gerretsen, F. C. (1931). Influence of temperature and moisture upon the nature and extent of decomposition of plant residues by microorganisms. Ecology, 12, 33-60.

Wang, Y., DeSilva, A. W., Goldenbaum, G. C., \& Dickerson, R. R. (1998). Nitric oxide production by simulated lightning: Dependence on current, energy and pressure. Journal of Geophysical Research, 103, 19149-19160.

Wang, W. J., Smith, C. J., Chalk, P. M., \& Chen, D. (2001). Evaluating chemical and physical indices of nitrogen mineralization capacity with an unequivocal reference. Soil Science Society of America Journal, 65, 368-376.

Weaver, J. E. (1926). Root development of field crops. London: McGraw-Hill.

West, N. E. (1990). Structure and function of microphytic soil crusts in wildland ecosystems of arid to semi-arid regions. Advances in Ecological Research, 20, 179-223.

West, N. E. (1991). Nutrient cycling in soils of semiarid and arid regions. In J. Skujins (Ed.), Semi-arid lands and deserts: Soil resource and reclamation (pp. 295-332). New York: Mercel Dekker.

Western Regional Climate Center (2009). http://www.wrcc.dri.edu/.

Westgate, M. E., Otegui, M. E., \& Andrade, F. H. (2004). Physiology of the corn plant. In C. W. Smith, J. Betran, \& E. C. A. Burnge (Eds.), Corn: Origin history, technology, and production (pp. 235-272). New York: Wiley Series in Crop Science, Wiley.

White, C. S., \& Thomas, C. J. (1999). Nitrogen contributions from precipitation to a corn field at Zuni, New Mexico. Paper presented at the Annual Meeting of the American Society of Agronomy.

Williams, M. A., Rice, C. W., \& Owensby, C. E. (2000). Carbon dynamics and microbial activity in tallgrass prairie exposed to elevated $\mathrm{CO}_{2}$ for 8 years. Plant Soil, 227, 127-137.

Wilson, L. G., \& Artiola, J. F. (2004). Soil and vadose zone sampling. In J. F. Artiola, I. L. Pepper, \& M. Brusseau (Eds.), Environmental monitoring and characterization (pp. 103-120). Burlington: Elsevier Academic.

Woodbury, R. B. (1961). Prehistoric agriculture at Point of Pines. Arizona: Memoirs of the Society for American Archaeology. 17.

Wymer, D. A. (1992). Trends and disparities: The Woodland paleoethnobotanical record of the Mid-Ohio Valley. In M. F. Seeman (Ed.), Cultural variability in context: Woodland settlements of the Mid-Ohio Valley (pp. 65-76). Kent: Kent State University Press MCJA Special Paper No. 7.

Zibilske, L. M., \& Materon, L. A. (2005). Biochemical properties of decomposing cotton and corn stem and root residues. Soil Science Society of America Journal, 69, 378-386.

Zou, X. M., Ruan, H. H., Fu, Y., Yang, X. D., \& Sha, L. Q. (2005). Estimating soil labile organic carbon and potential turnover rates using a sequential fumigation-incubation procedure. Soil Biology \& Biochemistry, 37, 1923-1928. 